2016-12-01

\title{
Redbeds of the Upper Entrada Sandstone, Central Utah: Facies Analysis and Regional Implications of Interfingered Sabkha and Fluvial Terminal Splay Sediments
}

Jeffery Michael Valenza

Brigham Young University

Follow this and additional works at: https://scholarsarchive.byu.edu/etd

Part of the Geology Commons

\section{BYU ScholarsArchive Citation}

Valenza, Jeffery Michael, "Redbeds of the Upper Entrada Sandstone, Central Utah: Facies Analysis and Regional Implications of Interfingered Sabkha and Fluvial Terminal Splay Sediments" (2016). All Theses and Dissertations. 6112.

https://scholarsarchive.byu.edu/etd/6112 
Redbeds of the Upper Entrada Sandstone, Central Utah: Facies Analysis and Regional Implications of Interfingered Sabkha and Fluvial Terminal Splay Sediments

Jeffery Michael Valenza

A thesis submitted to the faculty of

Brigham Young University

in partial fulfillment of the requirements for the degree of

Master of Science

Thomas H. Morris, Chair

Jani Radebaugh

Sam Hudson

Scott M. Ritter

Department of Geological Sciences

Brigham Young University

Copyright (C) 2016 Jeffery Michael Valenza

All Rights Reserved 


\author{
ABSTRACT \\ Redbeds of the Upper Entrada Sandstone, Central Utah: Facies Analysis and Regional \\ Implications of Interfingered Sabkha and Fluvial Terminal Splay Sediments \\ Jeffery Michael Valenza \\ Department of Geological Sciences, BYU \\ Master of Science
}

First distinguished from other sedimentary successions in 1928, the Entrada Sandstone has been the subject of numerous studies. The western extent of the formation was initially described as laterally continuous "earthy" red beds, and categorized as sub- to supratidal marineinfluenced sediments. Recent workers have reexamined the sedimentary facies hosted by the Entrada Sandstone, and findings suggest purely terrestrial depositional environments. Several outcrops of the upper Entrada hosted peculiar sedimentary features, including undulatory and convex-upward, parallel-laminated bedforms, reminiscent of hummocky cross-stratificationunexpected features in a terrestrial environment. The purpose of this study was to collect detailed outcrop measurements of these and other facies present in the upper Entrada Sandstone and to place them in context within a regional sedimentary system. Measured section data was analyzed and divided into sixteen primary facies based on textures, features, bedforms, grain size, and other characteristics. Surfaces were also noted and described. Each facies and surface was recognized to have developed under specific depositional or flow conditions, including eolian, paleosol, and fluvial subcritical, critical, supercritical, and waning flow. Primary facies were grouped into observed and interpreted facies associations. A depositional environment was then assigned to each facies association. These environments included sabkha, overbank splay/paleosol, distal terminal splay, and hyper-distal terminal splay.

Ancient analogs were found in the Blomidon, Skagerrak, and Ormskirk Formations, which have been described as dryland fluvial systems that terminated onto saline mudflats (sabkhas). Modern analogs were found in the central Australian continent, in the form of fluvial terminal splays in ephemeral Lakes Eyre and Frome. The sedimentary system of the upper Entrada Sandstone of the San Rafael Swell is interpreted as an interfingering fluvial terminal splay and inland sabkha system. These are marked by a wide array of sedimentary structures representing stark extremes, from hyperarid to flash flooding conditions. During arid conditions, the only source of water was evaporative pumping of a high water table. During the rare occasions when surface water flowed through the system, flash flooding events produced the highest stage of supercritical flow described in geological literature. The succession of these facies reveals allogenic and autogenic processes active at the time of deposition, including episodes of tectonic uplift and fluvial avulsions.

Keywords: Entrada Sandstone, sabkha, dryland fluvial system, fluvial terminal splay, supercritical flow, salt crust efflorescence, climbing ripples, antidunes, sand-patch fabric, Utah, Lake Eyre, Lake Frome, Blomidon Formation, Skagerrak Formation, Ormskirk Formation 


\section{ACKNOWLEDGEMENTS}

Funding for this research was provided by the Department of Geological Sciences at Brigham Young University.

I'd like to thank first and foremost my thesis advisor, Dr. Tom Morris. He not only encouraged an over-talkative and headstrong undergraduate to pursue Sedimentology, but took me on as a mentored research assistant. As a master's student, I couldn't have asked for a more experienced or committed thesis advisor, and Dr. Morris helped me learn the value of doing things the right way the first time. He was patient with my never-ending stream of questions, knowing when to answer them and when to let me find answers on my own. Dr. Morris helped direct that wide-ranging curiosity into academic rigor. Timely and invaluable counsel was frequently offered, coupled with hands-on learning opportunities, including lab and field research, conference presentations, and recruiting events.

Special thanks are given to Dr. Dario Ventra, who came out of his way to investigate the more perplexing outcrops and bedforms. Without his expertise in physical sedimentology and willingness to explain many finer points to me, key features and processes would have been missed that made meaningful conclusions possible.

I'd like to thank friends and colleagues who took time to assist me with section measurement, including Chanse Rinderknecht, Michelle Meadows, Trevor Tuttle, Kim Sowards, and my father, Michael Valenza.

Lastly, I thank my parents, Michael and Karen Valenza, for constant support, love, and encouragement. They taught me to work hard, strive for excellence, and to never hesitate to ask for help or offer help to those with whom I was privileged to work. 


\section{TABLE OF CONTENTS}

ABSTRACT

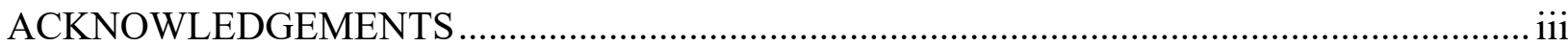

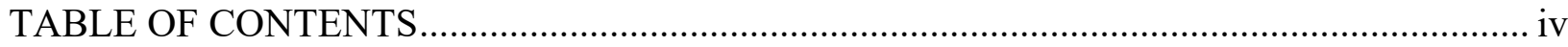

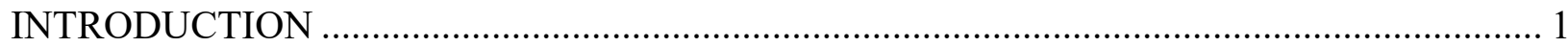

Purpose

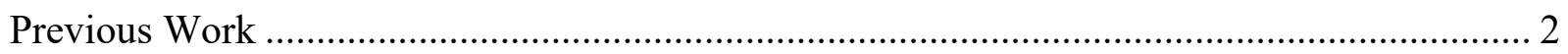

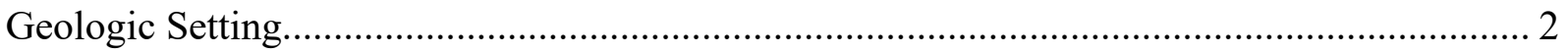

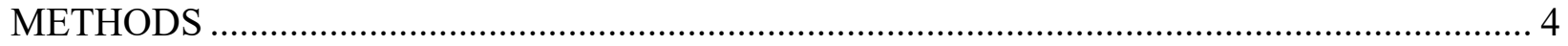

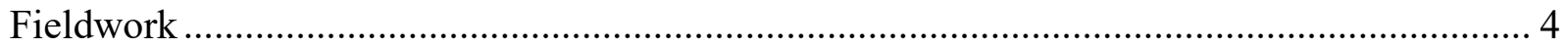

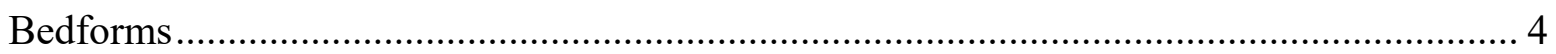

Measured Sections and Facies …………………….................................................... 5

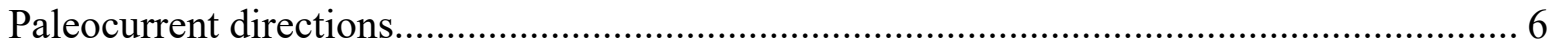

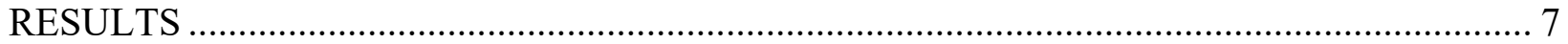

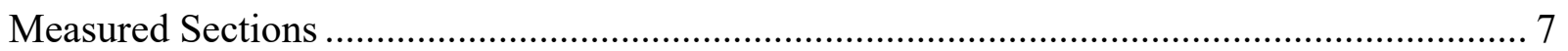

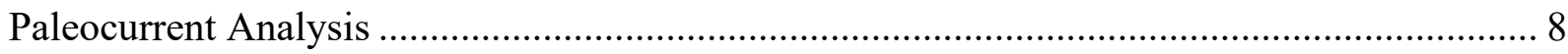

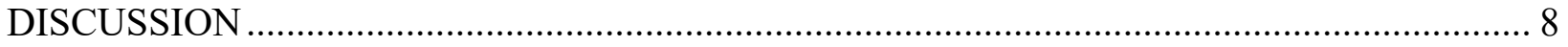

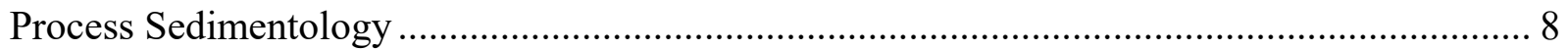

Salt crust development and related features................................................................. 8 
Supercritical Flow.

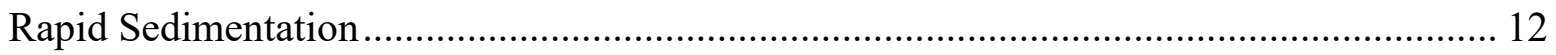

Physical Sedimentology - Primary Facies......................................................................... 12

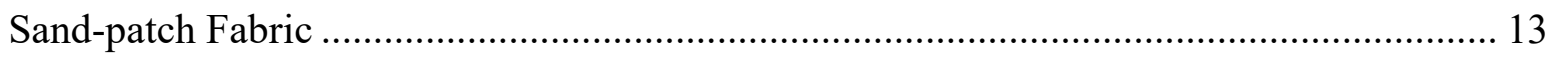

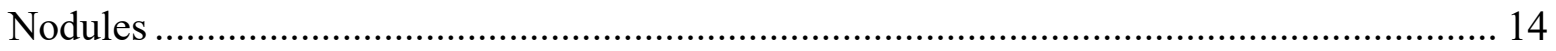

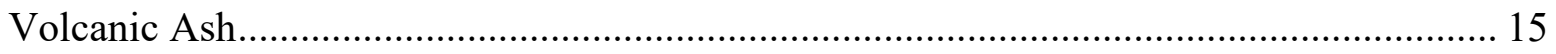

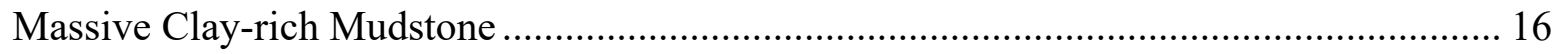

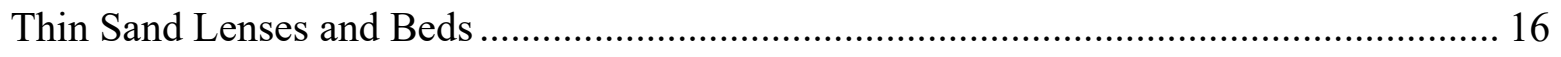

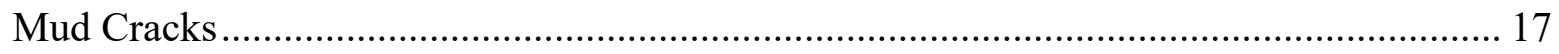

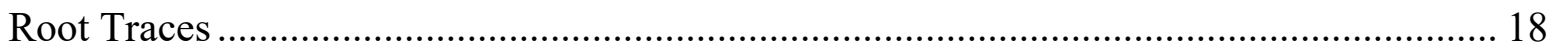

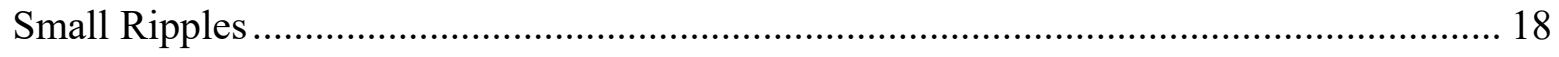

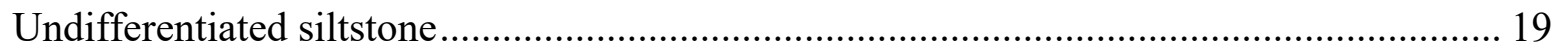

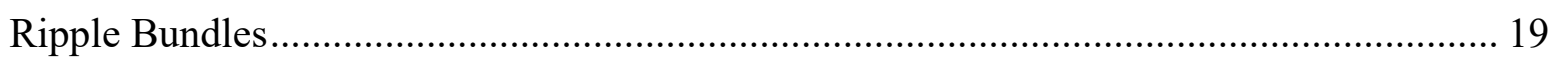

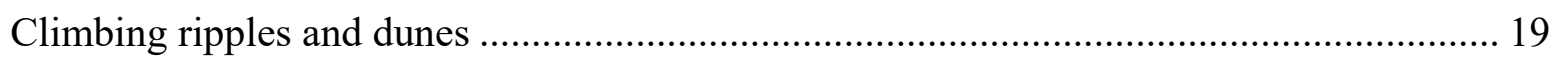

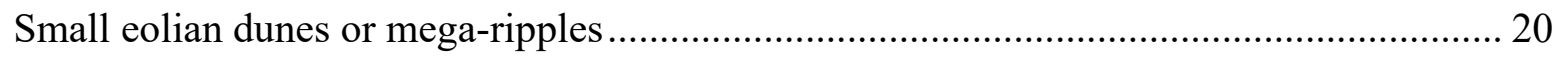

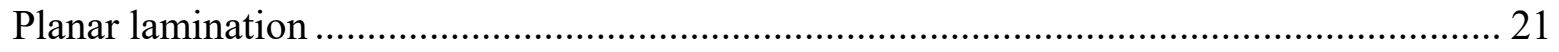

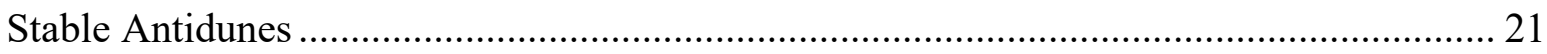

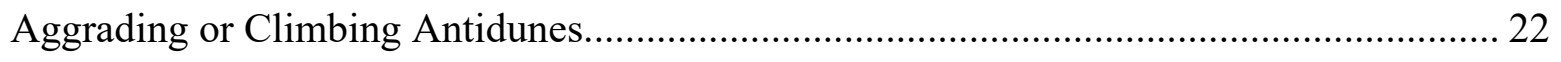

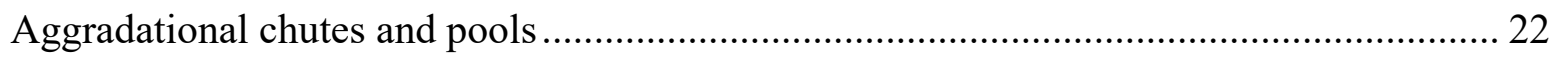

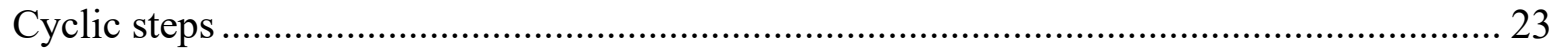




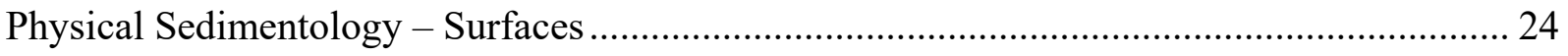

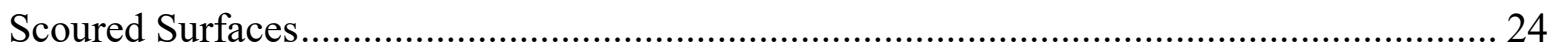

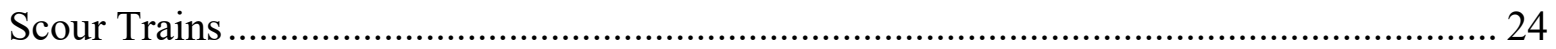

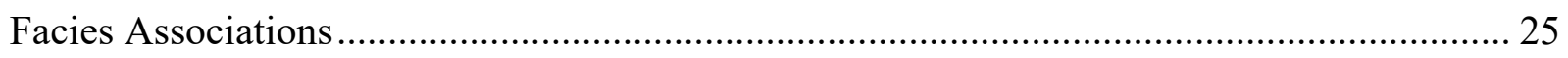

Facies Association A - Sabkha .............................................................................. 25

Facies Association B - Overbank Splay/Paleosol .................................................... 26

Facies Association C - Distal Terminal Splay ...................................................... 27

Facies Association D - Hyper-distal terminal splay ............................................... 30

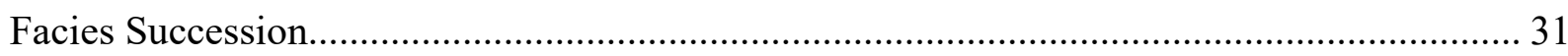

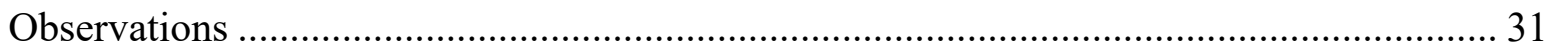

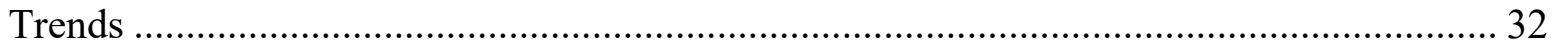

Interpreted Sedimentary System .................................................................... 33

Implications from Analogs and Observations........................................................ 38

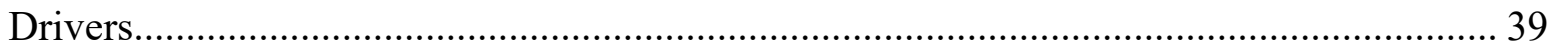

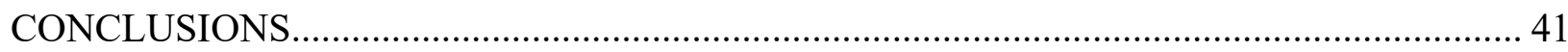

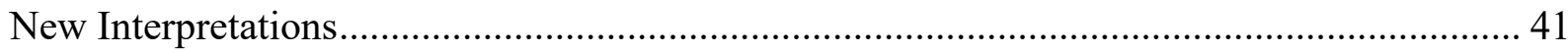

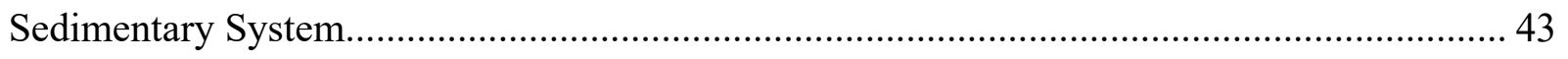

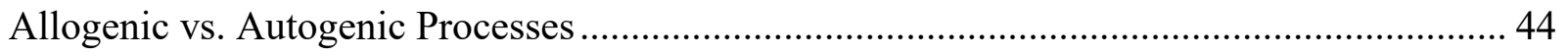

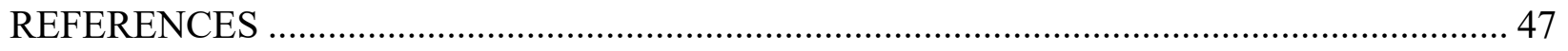

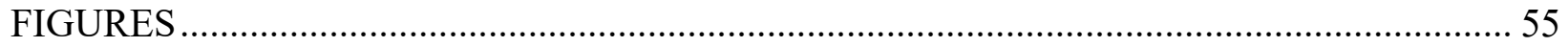




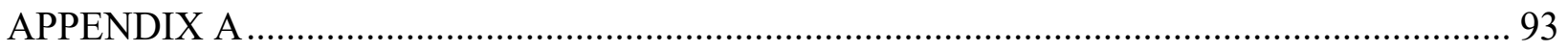

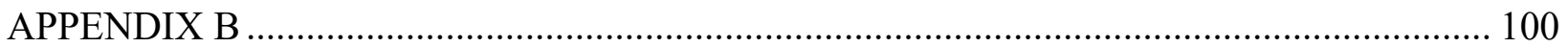




\section{INTRODUCTION}

\section{Purpose}

This study is an extension of the work begun by Hicks et al. (2010), who investigated the mudstone-sandstone facies transitions of the Entrada Sandstone. Outcrop studies conducted in the San Rafael Swell and near Escalante, UT, refined the interpreted depositional history, paleogeography, and sequence stratigraphy of the Entrada Sandstone. The upper portion of the Entrada Sandstone was interpreted as an erg margin-sabkha-tidal flat system. Of particular note was a recurring "storm" facies observed in the upper portion of the Entrada Sandstone in the western San Rafael Swell section. Hicks (2011) described these facies as hosting planar lamination and hummocky cross-stratification. As hummocky cross-stratification is typically thought to develop in a lower shoreface environment (Harms et al., 1975; Bourgeois, 1980; Dott and Bourgeois, 1982; Quin, 2011) the reporting of hummocky bedforms in an otherwise terrestrial to tidal environment required further investigation.

The purpose of this study is to observe, describe, and interpret sedimentary facies found within the upper Entrada Sandstone in the San Rafael Swell, Utah (Figure 1). Section measurements of the study interval at various locations serve as the primary data source, including observations of encountered features, units, and paleocurrent measurements. A brief review of results is followed by physical sedimentological observations and interpretations of primary facies. Facies associations are proposed, followed by a discussion of trends in facies successions. Observations, interpretations, and modern and ancient analogs are used to produce a unified depositional model for the upper Entrada Sandstone. 


\section{Previous Work}

The first descriptions of the Entrada Sandstone were made by scientists in the early $20^{\text {th }}$ century as part of geologic surveys of western Colorado and eastern Utah (Cross, 1907; Lupton, 1916; Emery, 1918; Dake, 1919; Longwell et al., 1923). Gilluly and Reeside (1928) were the first to differentiate the Entrada Sandstone as a distinct formation, naming it after the prominent Entrada Point located in the northern San Rafael Swell. Two stratigraphic expressions were recognized and described in the newly defined formation. The first included thick, cliff- and dome-forming units of well-sorted, clean sandstones, prominent in eastern Utah. These beds were likened to the eolian-deposited Navajo and Wingate Sandstones. The second expression, dominant in western portions of the Entrada Sandstone, was described as "earthy", or silt-rich, and less well-cemented. They noted peculiar weathering of the earthy beds into rounded forms, or bosses, today known as goblins and hoodoos. Gilluly and Reeside (1928) described these finer-grained beds as being water-lain, stating that the evenness and continuity of the beds likely indicated a marine depositional setting, although no marine fossil evidence was found.

Subsequent workers further differentiated the earthy facies as sabkha, shallow marine, and or tidal environments (Kocurek and Dott, 1983; Crabaugh and Kocurek, 1993), but the suggested marine-influenced depositional environment for the west-central Entrada went unchallenged into the next century. Smith (1976), Mariño and Morris (1996), and Hicks et al. (2010) interpreted these earthy beds as sabkha and tidally influenced deposits. Jennings (2014) was the first to suggest that these beds had an entirely terrestrial origin.

\section{Geologic Setting}

The Entrada Sandstone is conveniently exposed on all flanks of the San Rafael Swell, a Laramide uplift in central Utah (Burchfiel and Davis, 1975; Coney, 1976). The San Rafael Swell 
displays an extensive record of Mesozoic sedimentary systems. During the Triassic and Jurassic periods, predominantly terrestrial deposition was punctuated by repeated marine incursions (Stokes, 1980). Following the deposition of the eolian Navajo Sandstone, the Jurassic Sundance Sea transgressed into the area. This interior seaway resulted from Cordilleran crustal loading which rapidly increased accommodation in the retro-arc foreland basin (Dickinson, 1976; Kocurek and Dott, 1983; Jennings, 2014). The San Rafael Group was deposited during this relative sea level rise, and includes the Carmel, Entrada, Curtis, and Summerville Formations. Within the San Rafael Swell, the Carmel, Curtis, and Summerville formations represent marine and marginal marine facies, with varying water depths and varying amounts of terriginous influx (Stokes, 1980; Blakey et al, 1983; Peterson, 1994). The Entrada is the only widespread terrestrial member of the San Rafael Group, and was deposited during Middle Jurassic Callovian time, from approximately 168 to 161 Ma (Steiner, 1983; Dossett, 2014).

Topographic lows between the Cordillera to the west and the craton to the east provided accommodation for sediment eroding from both, as well as marine transgressions of the Sundance Sea from the north (Kocurek and Dott, 1983; Makechnie, 2010). During Callovian time, central Utah was located between 20 and 30 degrees north latitude, in an arid climatic setting (Figure 2). During this time, an erg system was active to the east (Kocurek and Dott, 1983). Westward, an alluvial apron was transporting large amounts of eroded material from the Elko fold belt (Perkes, 2010; Jennings, 2014). Marine mudstones and carbonates were being deposited to the north in the Sundance Sea (Cook, 2016). Adjacent, time equivalent successions preserved from this setting include eolian facies of the Entrada Formation, alluvial gravels and sands of the Twist Gulch Formation, and marginal marine to marine mudstones and carbonates of the Preuss Sandstone and Arapien Shale (Imlay, 1952; Kocurek and Dott, 1983; Cook, 2016). 
The interplay between tectonism, marine transgressions, and sedimentation rates contributed to the facies variation observed in the Entrada. (Kocurek and Dott, 1983; Blakey et al., 1988; CarrCrabaugh and Kocurek, 1998; Makechnie, 2010; Jennings, 2014, Cook, 2016).

\section{METHODS}

The first phase of work included field studies on two scales: 1- the morphology of individual sedimentary structures, and 2- the distribution of distinctly different beds (i.e. "storm" facies of Hicks et al., 2010), in terms of stratigraphy and lateral extent.

\section{Fieldwork}

\section{Bedforms}

First-phase observations of sedimentary structures included morphology, frequency of occurrence, and bedform assemblages. In addition, special attention was given to beds hosting peculiar sedimentary structures. Distribution trends were also noted. On a bed scale, observations included distribution of bedforms, grain size, thickness, contacts, and lateral extent. The heterogeneous nature of the upper Entrada Sandstone meant that individual beds were easily distinguished based on distinct changes in grain size, mud and silt content, and sedimentary features. Based on these differences, preliminary facies assignments were given to beds, which were used to consider facies associations and successions, including stratigraphic stacking and recurrence patterns.

A second phase of more detailed observations of bedform morphologies was conducted. These details included: wavelengths, amplitudes, internal lamina, and foreset lamination dip directions. These were used to classify bedforms, which in turn were used to interpret depositional conditions, including water depth, velocity, and sediment load. Several major 
breakthroughs occurred due to the discovery of literature regarding suitable modern analogs and consultation with Dr. Dario Ventra, during several days of field work. This allowed for refinement of facies classifications.

\section{Measured Sections and Facies}

The primary goal of section measurement was to document lithologic units and characteristics of the upper Entrada Sandstone. For this study, the upper Entrada was considered to begin at the top of the thickest massive sandstone unit, which was found to be over 20 meters in thickness at all field locations. This unit was interpreted to be a sabkha facies association, which makes up a significant portion of the Entrada's total thickness within the study area. This massive sandstone bed marks a distinct facies association change from the strata below and above it. The upper limit of the Entrada is considered to be the J-3 unconformity which is overlain by the Curtis Sandstone. The Curtis is marked by glauconite-rich sandstone and conglomerate beds. Discrete units of the upper Entrada Sandstone ranged from ten centimeters to ten meters. The following attributes were observed: contact, thickness, grain size, color, geomorphic expression, lateral continuity, and grading. Attributes of bedforms were given special attention, including dimensions, stacking patterns, and paleocurrent directions. A final bedform identification was then made. With details of these attributes noted, a primary facies assignment was given.

Beds were assigned one of four facies associations: A) sabkha, B) overbank splay/paleosol, C) distal terminal splay, and D) hyper-distal terminal splay. Seven sections were measured along the western flank of the San Rafael Swell (Figure 3). Three paired sections and one solitary section were measured. Section locations were chosen in order to observe proximal and distal variations. The first pair was measured immediately north and south of Moore Road, 
the second just north and south of Dutch Flat Road, and the third north and south of the Green River Cutoff Road. Each unit measured was assigned to a facies association. The percentage that each facies association made of each section was then calculated.

\section{Paleocurrent directions}

Foreset dip directions were measured throughout each measured section to determine trends in paleocurrent directions. These trends were sought in order to determine the fluid flow direction, which could in turn indicate the depositional center of the system. In some beds, only a two-dimensional or profile view was exposed. In other beds the tops of the bedforms were wellexposed, providing a three-dimensional view. Each paleocurrent measurement was recorded alongside its hosting unit in the section notes, and was marked as two- or three-dimensional. Measurements were then compiled and plotted in rose diagrams (APPENDIX B).

At first glance, strata contained in the upper Entrada appear to be laterally continuous as far as the eye can see, but upon closer inspection many of the beds exhibit changes in thickness, contact, and bedform assemblages. Especially true regarding the cleaner sandstones, thinner beds pinch out over distances of approximately 100 meters. Some appear to be 1-2 $\mathrm{m}$ thick in one location, but thin and pinch into two, three, or even four thinner beds at distance. Because of this variation, many of these cleaner sandstones were walked out along strike to find the range of bedforms, observe trends in lateral thickening or thinning, and obtain paleocurrent directions. At one location near the Moore Road North section, a bed was observed in detail over a distance of $360 \mathrm{~m}$ to determine how beds change with distance (Figure 37, discussed in Facies Association C - Distal Terminal Splay ). 


\section{RESULTS}

\section{Measured Sections}

Seven upper Entrada outcrops along the western flank of the San Rafael Swell were measured, from the top of the middle Entrada sabkha to the J-3 unconformity Curtis contact (Figure 3 and Figure 4). While each section varied in total thickness and the number and assortment of units, recurring features and characteristics were observed that provided data for the creation of a regional facies model. The sections were correlated using a continuous ash bed as a benchmark. The ash bed was found within a thick sabkha unit at each location. The enveloping sabkha unit ranged from 3.5-10.6 m thick. One exception was the section measured at Cedar Mesa. While bed types here are nearly identical to those found at other outcrops, the only visible ash bed was found near the top of the middle Entrada sabkha interval. This ash bed could not be verified as the same bed found in other sections, but it was used as a starting point for section measurement, resulting in the longest section of the study.

Units encountered in the Moore Road sections include: very thick (up to approximately 6 m) cliff-forming beds of rusty colored, silty sandstone containing disturbed wispy laminations and irregularly shaped sand lenses $1-10 \mathrm{~cm}$ in length; thin to thick (from less than $10 \mathrm{~cm}$ to almost $1.5 \mathrm{~m})$ recessive beds of dark red to purple clay-rich mudstones; thin $(3-10 \mathrm{~cm})$, ledgeforming continuous white/gray sandsone beds; medium to thick (.3-1.5 m) ledge-forming sandstone sheets, beds of well-sorted sandstone typically exhibiting a variety of well-preserved bedforms; thin to medium to thick (0.15-1.5 m) slope-forming beds of siltstone; medium (10-20 $\mathrm{cm})$ sandstone beds of ripple bundles that pinch and swell; and thin $(10 \mathrm{~cm})$ beds of purple bentonite claystone. Other sections host beds with nearly identical characteristics, but with 
variable thicknesses and stacking orders. Total thicknesses of the upper Entrada interval range from approximately 24 to 44 meters within the study area (see APPENDIX A for section tables).

\section{Paleocurrent Analysis}

Various bedforms were used to obtain paleocurrent directions at each section location, including ripples, small dunes, and climbing ripples. A total of 72 measurements were taken (APPENDIX B, Table 1), including 63 from sub-aqueous and 9 from sub-aerial bedforms. Plotting subaqueous data in rose diagrams (APPENDIX B, Figs. 1-7) yields mean vector directions ranging from $82^{\circ}$ to $143^{\circ}$ azimuth, with a combined mean vector of $99.8^{\circ}$ for all measurements (Figure 5 and Figure 6). Mean vector directions varied slightly, but some locations varied to more northeast directions, and some to more southeast, with no apparent trend (Figure 7 ). Several eolian current directions were measured, including several eolian sand units near the Moore Road North and I-70 sections. The mean vector for all eolian features was $231^{\circ}$ azimuth (Figure 6).

\section{DISCUSSION}

\section{Process Sedimentology}

The variety of sedimentary structures present in the study interval suggests that several distinct sedimentary processes were at work in the ancient environment. The most influential of these processes included salt crust development, supercritical flow, and waning, high-sedimentload flow.

\section{Salt crust development and related features}

The most common sedimentary textures present in the study area are wispy-lamination and irregular sand lenses. These textures are typically found together, making up approximately 
$90 \%$ of the beds interpreted as sabkha facies. Similar textures are described by Smoot and Castens-Seidell (1994) and Goodall et al., (2000), and are attributed to salt crust entrapment of windblown sediments. Thick deposits of such textures are interpreted to result from a persistent salt flat environment. This environment develops in topographic lows in arid climatic settings, and is defined by the presence of a surficial salt crust.

Salt crusts are produced by three primary processes, including evaporation of standing surface water, evaporation of near-surface saline groundwater, and eolian erosion, transport, and re-deposition of salt from other crusts (Figure 8) (Smoot and Castens-Seidell, 1994; Goodall et al., 2000). In the first process, the majority of salt crystallization occurs underwater, where large crystals can develop during evaporation of surface floodwaters. The last two processes are termed "salt crust efflorescence" (Smoot and Castens-Seidell, 1994), where crystallization occurs solely through evaporation of salt-laden water films coating sediments. Salt crust efflorescence produces thinner crusts that more delicately imitate the surface on which they grow, with minimal disturbance of previous-laid sediments.

It is important to note that the development of salt crusts in the situations discussed here never attain such thicknesses as to be preserved in the rock record. "Thick" and "thin" salt crust descriptions are relative, here referring to accumulations of salt that cannot survive the relative water table rise that accompanies burial. A variety of sedimentary textures and features fall into this "ephemeral salt" category, but only those found within the Entrada are discussed here.

Seasonal filling of ephemeral lake beds or storm and tide-related flooding of coastal areas introduce standing water of variable salinity. This water may dissolve surface salts, producing coarse grains of halite. This process continues until all surficial water has evaporated, and typically produces the thickest salt crusts. In locations where groundwater is close enough to the 
surface to undergo evaporative pumping, capillary transport of water through the unsaturated zone allows salt crust efflorescence to develop on the sediment surface. In other locations, strong winds can erode the crust, and transport salt dust beyond topographic lows. In the event of rainfall, this salt dust dissolves and recrystallizes as a thin crust. Any combination of these processes is possible, and the thickest crusts develop in topographic lows where more water is available for evaporation, be it shallower groundwater, or more frequent inundation.

\section{Supercritical Flow}

Cartigny et al. (2013) provide a thorough review of the morphodynamics and sedimentary structures produced by supercritical-flow conditions. The supercritical flow threshold is calculated using the Froude number:

$$
\begin{array}{ll}
\left(F r=\frac{U}{\sqrt{g h}}\right) \quad & \text { Where: } \\
& F r=\text { Froude number } \\
& U=\text { flow velocity } \\
& g=\text { gravity } \\
& h=\text { flow depth }
\end{array}
$$

A value exceeding unity indicates supercritical flow, achieved when the velocity of a fluid $(U)$ exceeds the wave propagation velocity $(\sqrt{ } g h)$. Gravity is an acceleration, and will therefore have an exponentially greater influence than velocity with increasing flow depth. As a result, supercritical flow in deeper water demands an increasingly faster fluid velocity. Conversely, shallow fluid flows can achieve supercritical conditions at relatively low velocities. Supercritical flows can be further divided using the Reynolds (Re) and Vedernikov (Ve) numbers: 


$$
R e=\frac{U h}{v} \quad V e=x F r
$$

Where:

$R e=$ Reynolds number

$U=$ fluid velocity

$h=$ fluid depth

$v=$ fluid viscosity
Where:

$V e=$ Vedernikov number

$x=$ dependency of flow velocity on depth

(either $1 / 2$ or $2 / 3$ may be used)

$F r=$ Froude number

These numbers describe thresholds between laminar and turbulent flow and stable and unstable flow. A flow changes from laminar to turbulent when fluid velocity of the fluid column sufficiently exceeds the viscosity of the fluid. Stable flow ceases when turbulence (described by the Reynolds number) increases to the point that surface waves separate from the main current and begin breaking upstream (Chow, 1959; Cartigny et al., 2013). The different bedforms known to form in supercritical flow conditions develop in different combinations of laminar or turbulent and stable or unstable flow.

Under these conditions, sedimentation occurs at locations where decreases in velocity develop due to flow instabilities and frictional forces between the sediment surface and the fluid flowing over it. When the fluid arrives at one of these locations, the fluid column increases in height, as faster flowing fluid is forced to slow down, resulting in a "pile-up". These changes in velocity, marked by taller fluid columns, are called hydraulic jumps (Cartigny et al., 2013). The difference between ingoing stream velocity and the slower velocity zone determines the magnitude of the jump, as well as the style of sedimentation. Fluid entering a hydraulic jump deposits sediment (due to a decrease in velocity), but as soon as the fluid passes a zone of flow instability, supercriticality, original competency, and grain transport resumes. As deposition beneath the hydraulic jump continues, the hydraulic jump is amplified. When upstream and downstream forces are out of balance, hydraulic jumps are known to migrate in the direction of 
stronger forces. This phenomenon is described as "surge" by Cartigny et al. (2013). In summary, supercritical flow conditions are common to environments that contain high velocities relative to flow depths. The spatial arrangement and amplitude of hydraulic jumps determine what type of supercritical bedforms develop, ranging from antidunes to cyclic steps. The interested reader is encouraged to see Cartigny et al. (2013) for detailed treatment of the full range of supercritical bedforms, including flow conditions, morphology, and interior lamination.

\section{Rapid Sedimentation}

Rapid sedimentation typically occurs as a result of waning flow conditions. Generally, changes in fluid depth, channel width, channel slope, or some combination of all three can cause a decrease in flow velocity. This causes a decrease in competency, and sedimentation occurs. If a fluid has a high sediment load, small changes in velocity can provoke sedimentation. A rapid decrease in velocity can cause rapid sedimentation. Ashley et al. (1982) describe flume experiments where two types of climbing bedforms were observed, those experiencing stoss erosion (leaving only foresets preserved), and those experiencing stoss deposition (leaving topsets and foresets perserved). The first type was produced when aggradation rates were small relative to bedform migration rates, while the second were produced when aggradation rates were large relative to bedform migration rates. Both types of climbing bedforms are found in the study area.

\section{Physical Sedimentology - Primary Facies}

Process sedimentology was used as the primary tool to interpret the sedimentary system of the upper Entrada Sandstone. Thus, a facies scheme was developed that focused on sedimentary processes, as opposed to lithology or environment (e.g., sandstone facies, sabkha facies, etc). In this section outcrop observations are divided into primary facies. These serve as 
the smallest units utilized in this study, and are based on primary and/or secondary sedimentary features. Thus the term "primary facies" refers to a unit containing sedimentary features that result from a single sedimentary process, including energy and flow conditions. Observations are presented first, followed by an interpretation of the conditions under which each primary facies formed. Primary facies are presented in order from lowest to highest interpreted energy conditions.

\section{Sand-patch Fabric}

As mentioned previously, the most common sedimentary features within the study interval include wispy lamination and irregular sand lenses (Figure 9). Wispy lamination is visible as faint, wavy bands of darker, finer-grained material distributed throughout massive sandstone. Irregular sand lenses exhibit a wide range of morphologies, from $1-15 \mathrm{~cm}$ in length, $1-5 \mathrm{~cm}$ in thickness, and varying degrees of internal lamination, from none to what appear to be small eolian foreset laminae. Contacts with the surrounding wispy-laminated sandstone range from smooth to cuspate, flat to rounded, and horizontal to nearly vertical. In addition, wispy lamination varies in concentrations of fines, from very faint, wavy laminae to nearly pure siltstone forming a matrix around sand lenses. Wispy lamination and irregular sand lenses typically occur together, although in some instances only wispy lamination is visible.

Smoot and Castens-Seidell (1994) describe thicker salt crusts as hosting patches or lenses of sand ("sand-patch" fabric), entrapped by blocky, irregular salt crusts developed in the lowest relief areas of a salt flat or sabkha (Figure 10). However, Goodall et al. (2000) describe the development of salt blisters in thin crusts that can create accommodation for windblown sediments. This accommodation is found between blisters and even within ruptured blisters, and is documented in the modern at inland locations of the At Taf sabkha, in the United Arab 
Emirates. Goodall et al. (2000) interpret sand-patch fabric in core samples from the Ormskirk Sandstone in the North Sea to exemplify this phenomenon in an ancient sabkha environment (Figure 11). Both types of crust employ the same two trapping mechanisms. The first is the simple trapping of coarse grains (sand) in topographic lows and wind breaks. The second mechanism results from the hygroscopic properties of salt: a thin film of water on the surface of a salt crust dissolves a small amount of salt. The resulting solution has different chemical properties than that of pure water, including a lower evaporation rate (Wise et al., 2007). This produces a slightly wet surface that catches small windblown particles (silt and clay). As crust (along with trapped sediment) is buried, it passes below the water table, which dissolves the salt. With the dissolution and removal of salt, finer grains are concentrated into wispy, wavy laminations of silt and clay surrounding sand lenses. The resulting siliciclastic lag results in the characteristic sand-patch fabric described by Smoot and Castens-Seidell (1994) and Goodall et al. (2000), also observed in this study.

In addition, both research teams describe salt-dissolution collapse features (Smoot and Castens-Seidell, 1994; Goodall et al., 2000). These are thought to form through the loading of sediment above a unit of salt, which then dissolves preferentially under the increased pressure. This in turn creates more accommodation for more sediment, resulting in more dissolution. Photos and diagrams supporting this idea have no known analogs in the Entrada Sandstone, although convoluted bands of wispy lamination and irregular sand lenses suggest that a similar version of this process may have occurred (Figure 12).

\section{Nodules}

Irregular quartz nodules were encountered infrequently throughout the study area, but were found at least once in each section (Figure 13). Ranging from very coarse sand-sized to up 
to a centimeter in diameter, these features were found to occur as sub-units within massive sandstones exhibiting sand-patch fabric. Often occurring in diffuse horizontal bands, they ranged in concentration from one per meter to one per centimeter, and were also found to form clusters of nodules up to $10 \mathrm{~cm}$ wide. They were typically composed of clear, white, and red-colored (jasper) quartz minerals.

Massive sandstones hosting quartz and red jasper nodules make up the rest of the sabkha facies association. Goodall et al. (2000) suggest that nodules develop when the capillary fringe remains stationary for extended periods of time. In this setting, prolonged precipitation of salt in pore spaces displaces sediment. Over time, these salt nodules are immersed by water table rise, either during normal fluctuation or during burial. Consequently, some salt nodules are dissolved, and the resulting voids may collapse. This further disturbs sedimentary textures, and can completely erase all traces of previous sedimentary textures and features. Any nodules that aren't dissolved, or are dissolved but leave voids, are later replaced or filled by silica cement during diagenesis.

\section{Volcanic Ash}

Dark purple clay beds displaying a "popcorn" texture and recessive outcrop expression were found, one per section, with the exception of the I-70 section, which hosted two. These beds were found within massive sandstone units of facies association A. Immediately surrounding the clay beds, sandstone units exhibited strong bleaching that faded from the contact over a distance of approximately $20 \mathrm{~cm}$ (Figure 14).

These dark clay units are interpreted as ash beds. Volcanic material, especially glass-rich ash, decomposes to clay minerals, typically expanding clays, such as bentonite, or smectite (Roen and Hosterman, 1982). In addition to providing a unit by which to correlate stratigraphic 
columns, beds of ash, or tephra, permit a tephrochronological analysis, a stratigraphic dating method based on volcanic events (Lowe, 2010). The continuous ash bed in the study interval was dated by Dossett (2014) and yielded an age of 160.8 $\pm .2-.4$ million years, for two sample locations within the San Rafael Swell. Ash within the Entrada Sandstone is attributed to magmatic arc volcanism, resulting from subduction of oceanic crust along the continental margin to the south and west (Christiansen et al., 1994; DeCelles, 2004). While ash beds are included in the sabkha facies association, they are not included in percentage statistics as they represent rare events outside of local depositional conditions.

\section{Massive Clay-rich Mudstone}

Thin to medium (15-150 cm thick) beds of recessive, dark red, clay-rich mudstone were found throughout the study interval (Figure 15). These beds were found to be featureless, and were identified based on grain size and lack of sedimentary structures. Basal contacts were relatively sharp, but not erosional.

Energy conditions for this facies are interpreted to be the lowest of water-lain facies found within the study interval. These mudstones are likely a result of flooding of topographic lows, where suspended clay and silt grains were able to settle out over time. The general lack of sedimentary structures suggests that there was some process in place that prevented the development of structures, or that destroyed any structures that might have formed. High mud content may have prevented tractional load bedform development, or repeated episodes of wetting and drying may have created destructive desiccation cracks.

\section{Thin Sand Lenses and Beds}

Clay-rich mudstone beds were always found to contain thin sand lenses and beds $(1-5 \mathrm{~cm}$ thick). Beds tended to be very continuous, and lenses tended to range from $5-15 \mathrm{~cm}$ long. These 
sand units were composed of very fine, bleached white sand, and were typically structureless, like the hosting mudstone units (Figure 16). No correlation was found between the overall thickness of a mudstone bed and the number of hosted thin sand units.

This facies is interpreted to be the result of small, low sediment load flow events. Such flows distributed small quantities of sand into low lying areas that were otherwise accumulating silt and clay grains.

\section{Mud Cracks}

While most mudstone units were found to be lacking laminations or sedimentary structures, some were found to host vertical wedge-shaped sandstone features. These appear to occur as secondary features in the unit, cutting through mudstone units. These features ranged from $\sim 1-10 \mathrm{~cm}$ in length, and $1-3 \mathrm{~cm}$ in width, always narrowing to a point at the base (Figure 17). On several occasions similar sandstone features were found alongside more common wedge shapes. These formed vertical, horizontally elongated, and intersecting walls in the hosting mudstone unit (Figure 18). Occasionally, where ledge-forming sandstone units overlie mudstone units, polygonal shapes were visible on the underside of the overhanging ledges.

Vertical downward-facing intrusions of sandstone into mudstone units were interpreted as classic "daggers" formed by the filling in of mud cracks. With white sand as the sediment fill within a dark red mudstone, these features were immediately eye-catching during section measurement. Mud cracks develop as water-saturated, clay-rich sediments dry. As water evaporates from the clay, shrinking clay minerals cause the bed to contract into polygonal shapes. This creates void spaces within the unit. Subsequent deposition of sand then occurs, filling voids and depositing thin beds above desiccated surfaces. In all observed mud cracks, sand fill was white, which suggests that bleaching occurred. Bleaching may result from the 
presence of organic material within the mudstone. This would have oxidized and bleached the sand as a relative rise in the water table accompanied burial.

\section{Root Traces}

Clay-rich mudstones also hosted narrow (several $\mathrm{mm}$ ) white, vertical, ovoid, or point features (Figure 19). These tended to be up to $5 \mathrm{~cm}$ in length, and exhibited crooked, non-linear geometry.

These features were interpreted as root traces. Vertical or point, and non-linear geometry are a result of root growth. Upon death and decay of plant material, decomposition bleached sediment to the present white color.

\section{Small Ripples}

Small foresets were found in two types of units, white sandstone units within clay-rich mudstones, and more rarely, at the top of a ledge-forming sandstone sheet. In the first setting, small ripple foresets typically $2-3 \mathrm{~cm}$ tall are preserved. In the second setting, ripples are observed in plan-view, when the unit above the sandstone sheet is recessive, and the top of the bed is exposed.

In both settings, small ripples are interpreted as being water-lain. In either case, fluid flow conditions were among the lowest energy observed in the study interval. Ripples within mudstone units are not well preserved, and only portions of ripple structure are visible, preventing precise measurement of height to length ratios needed to determine eolian or aqueous origin. Ripples found at the top of sandstone sheets are nearly symmetrical, and so small as to prevent further interpretation. 


\section{Undifferentiated siltstone}

While most of the upper Entrada hosts well-preserved sedimentary structures and textures, this was one facies in which no features were recognized. In almost every location, outcrop exposure of these beds were slope-forming, and even in large cliff outcrops, little more than faint, discontinuous stray laminations were present.

This facies was labeled and interpreted as undifferentiated siltstone. It is likely a result of flow events hosting a high sediment load, particularly in the fine grain size range, which prevented tractional bedform development.

\section{Ripple Bundles}

Medium-sized (up to $5 \mathrm{~cm}$ high, up to $10 \mathrm{~cm}$ long) asymmetrical ripples were most commonly encountered in thin beds $(10-20 \mathrm{~cm})$ that pinched and swelled, and contained anywhere from one to four stacked ripple sets (Figure 20). These were found within undifferentiated siltstone beds.

Thicknesses and stacks of these beds were highly variable, so they were labeled ripple "bundles". This facies is thought to result from flow events where finer grains were either bypassed or absent, allowing the better sorted and sandy sediment load to develop tractional bedforms. These ripples represent periods of increased flow velocity or a pulse of sediment with lower mud-to-sand ratio.

\section{Climbing ripples and dunes}

While some ripples and small dunes are present in the study interval, it is uncommon to see classic ripple and dune bedforms in single-story trains. The most common features observed in sandstone sheet units were vertically stacked, laterally migrating ripple laminae. Lamina set 
bounding surface angles ranged from approximately $12-20^{\circ}$ within individual units. This facies was typically found at the top of sandstone sheets, and where a 3D view was exposed due to a recessive overlying unit, ripples were found to have developed a $3 \mathrm{D}$ or $2 \mathrm{D}$ propagation front. In many locations, only foreset laminae were preserved, while in some locations some or all of the topset laminae were also preserved (Figure 21 and Figure 22).

Horizontally and vertically aggrading laminae were interpreted to be climbing ripple facies. In some instances ripple laminae were large enough to be considered mega-ripples or small dunes, but the flow conditions are considered to have been very similar. These facies are the primary manifestation of rapid sedimentation rates, indicating waning flow during deposition.

\section{Small eolian dunes or mega-ripples}

Several locations within the study area contained clean white sand units that hosted rippled lamina that made up large $(5-10 \mathrm{~m})$ dune sets.

An additional sandstone facies was observed 6-8 meters below the upper Entrada interval, described by Hicks (2011) as the Bitterseep Wash Sandstone. This subunit represents a brief eolian dune progression through the area, and eolian paleocurrent directions were taken at the Moore Road North and I-70 section locations. Only one unit within the upper Entrada exhibited an eolian dune facies, as the cap to a small mesa $200 \mathrm{~m}$ south of the Moore Road North section. It is important to note that this facies was not found within any of the lines of measured sections, but is still considered to be an important climate and depositional system indicator. Paleocurrent directions were taken at the several outcrops hosting this facies. 


\section{Planar lamination}

Sandstone sheets were found to host intervals of thin to very thin ( $3 \mathrm{~cm}$ or less) parallel laminae that never rose above a horizontal orientation (Figure 23).

These laminae are interpreted as planar lamination, and represent near-critical aqueous flow conditions.

\section{Stable Antidunes}

Also hosted by sandstone sheets, some laminated intervals were similar to planar laminated facies, but individual laminae exhibited thickening and thinning with some distance (0.5-1 m), and were terminated by overlying laminae (Figure 24). These were labeled as subplanar lamination in section measurement notes.

This facies is interpreted as an increase in criticality from planar lamination, which led to the production of antidunes. This facies was deposited by the lowest stage of supercritical flow conditions. These bedforms mark the initiation of upstream-verging deposition (Cartigny et al., 2013). In this stage of supercritical flow, fluid flow is stable, and maintains an even depth. Subtle imperfections along the sediment-water interface exert friction on the water column, causing slight decreases in velocity, or undular hydraulic jumps (Cartigny et al., 2013). Deposition occurs at these locations, forming small antidunes. As they develop, they create more pronounced topography, in a positive feedback cycle. This continues until the steepness of the back limb allows for a velocity increase, which then initiates erosion. As antidunes develop, they deposit foresets that dip upstream, in the direction of migration, as backsets are eroded and reworked into subsequent antidune forms. In the stable antidune facies, all that is preserved is a sub-planar set of lamina that terminate into one another (Cartigny et al., 2013). 


\section{Aggrading or Climbing Antidunes}

Another sedimentary feature found within Entrada sandstone sheets includes

symmetrical, convex-upward, parallel laminated bedforms. These bedforms are typically 10-15 $\mathrm{cm}$ in length, and around $5 \mathrm{~cm}$ in height. Little interruption of laminae was observed, except in the troughs between crests, and even then, many laminae were traceable over two or three wavelengths (Figure 25 and Figure 26).

There are few descriptions of such well-preserved supercritical bedforms, suggesting a rare combination of depositional conditions. Typically, bedforms are recognized by dip orientations of partially preserved lamina sets (Lang and Winsemann, 2013; Cartigny et al., 2013). One possible explanation for this facies is the development of a stationary hydraulic jump. There is little to no upstream or downstream migration of the hydraulic jump (surge). Instead, deposition of sediment occurs in the same location, with stacking of consecutive laminae. In these flow conditions, laminae can perfectly mimic each other (aggrading), or they can build off of each other, but slowly grow in a preferred direction (climbing).

\section{Aggradational chutes and pools}

Bedforms exhibiting large-amplitude sinusoidal morphologies were observed in one location. Internal laminae are parallel, with few visible terminations. Individual laminae or lamina sets can be followed from a lower trough up to a middle crest ( $\sim 10 \mathrm{~cm}$ gain), followed by a small dip (1-2 cm loss) to a middle trough, which is followed by another rise to an upper crest (3-5 cm gain). Continuous and parallel laminae appear to be filling troughs, as well as aggrading on crests (Figure 27). These bedforms continue for a distance of approximately $4 \mathrm{~m}$ along the outcrop, and appear to make up the majority of the hosting sandstone sheet unit. Some erosion 
between lamina sets is apparent, but general crest and trough locations are maintained between stacked lamina sets.

One possible interpretation of these sedimentary features, though not a perfect match, is that they are a type of chutes and pools structure. These features are characterized by trains of upstream-building bedforms that are separated by steep, downstream-dipping drops (Cartigny et al., 2013). Using flume studies to determine flow and sedimentation phenomena, Cartigny et al. (2013) attribute the large variability of surface dipping angles to a wide variation in hydraulic jump magnitude. Chutes and pools facies are interpreted to result from flow conditions that produce a high variability in hydraulic jump magnitude, between intervals of more stable, but

still supercritical, flow. This facies found within the upper Entrada is interpreted as aggradational chutes and pools.

\section{Cyclic steps}

This facies is characterized by gently dipping laminae that climb at an angle of approximately $20^{\circ}$ and are approximately $15-20 \mathrm{~cm}$ in length (Figure 28). Laminae descend from the bounding surface in a sigmoidal path to a lower position at the next bounding surface.

These laminae are interpreted to record cyclic steps, the highest constructive stage of supercritical flow (Cartigny et al., 2013). In this stage, large hydraulic jumps are developed, followed by stable flow conditions (similar to those that form stable antidunes), which deposit one set of continuous upstream-dipping laminae, until the next large hydraulic jump. Stability of flow between jumps results in longer uninterrupted laminae lengths than other supercritical flow structures. 


\section{Physical Sedimentology - Surfaces}

The following sedimentary features represent the highest energy conditions found within the study area. These features cause erosion and produce easily identifiable and important surfaces.

\section{Scoured Surfaces}

The study interval contained a full range of bed contacts, from faintly visible gradational to deeply scoured surfaces. The highest level of scouring was found at the bases of sandstone sheets. While some scours were irregular or horizontal and lacking any distinctive dipping angles, other scours appeared in clusters and formed distinctly symmetrical, scallop-shaped contacts. In several locations where a mudstone unit sat below the sandstone sheet, scours were easily visible from below the ledge-forming sandstone (Figure 29).

Flute casts are scour-and-fill features that form parallel to the direction of flow (Prentice, 1956). Noses form at the first point of erosion, and flare downstream, thus serving as useful paleocurrent indicators. Flute casts are typically asymmetrical parallel to flow, with the deepestscoured portion closer to the nose than the downstream side (Pett and Walker, 1971). In the study area, flute casts, are rare, but when present occur at the base of sandstone sheets at erosional contacts (Figure 23 provides a profile view, while Figure 29 provides a plan view).

\section{Scour Trains}

In several locations, erosional contact surfaces exhibited repeated, sinusoidal morphology. These surfaces typically included 3-6 wavelengths of 0.2-1 m scours, and had eroded into siltstones or other sandstone sheet units (Figure 30 and Figure 31). 
The conjunction of these rare forms of scours with other upper flow regime facies suggests some interesting possible connections between equilibrium bedforms and equilibrium scouring in shallow, rapid fluid flows. It is possible that these scours record hydraulic jumps and breaking waves in the same genre as those that form antidunal bedforms. The difference may be that where antidunes would experience deposition of sediment in the upstream direction, these scours simply experience diminished erosion at hydraulic jumps, but energy conditions are still too high to deposit sediment.

\section{Facies Associations}

Using observations from initial reconnaissance and section measurement at Moore Road, facies were sorted into one of five facies associations for which depositional environments were interpreted. Interpretations are based on assemblages of physical primary sedimentological features, grain size distribution, nature of contacts, and secondary sedimentary features such as haloturbation, desiccation, scouring, and stratigraphic stacking patterns. These characteristics are used to interpret the depositional conditions that persisted through multiple depositional events. Model stratigraphic columns for each facies association were created to demonstrate diagnostic characteristics, including stacking patterns, contact styles, and primary facies distribution.

Associations and their interpreted depositional environments are based on dryland fluvial and sabkha sedimentary systems described by Hubert and Hyde (1982), Goodal et al. (2000), Lang et al. (2004), Nichols and Fisher (2007), Fisher et al. (2008), and McKie (2014).

\section{Facies Association A - Sabkha}

Facies association A includes sand-patch fabric, nodule, and volcanic ash facies. Sandpatch and nodule facies occurred within close proximity of each other, and gradual transitions 
from one to the other were observed. Figure 32 provides a model stratigraphic column of this facies association, with a separate model for a typical ash bed shown in Figure 33.

This facies association is interpreted to be the product of a sabkha depositional environment. All variations in sedimentary textures and structures are dependent on the depth of the water table in relation to the sediment surface (Goodall et al., 2000). More specifically, sand lens size is dependent on the thickness of the salt crust. Thicker crust, which develops in locations with very shallow groundwater, provides the most accommodation, thus producing larger sand lenses. Thinner crusts create smaller accommodation which produces smaller lenses, and in the thinnest crusts, only moderate deformation of the top centimeter or two of the sediment surface occurs (Goodall et al., 2000). When sediment is buried but stays within the vadose zone for prolonged periods of time, all structure can be destroyed. In these circumstances, salt precipitates in pore spaces and allows the growth of salt nodules. Rising groundwater levels can dissolve nodules, causing small collapse features. If this process repeats, with fluctuating groundwater depths, multiple cycles of nodule growth, dissolution, and collapse erase all sedimentary features, producing a massive sandstone.

\section{Facies Association B - Overbank Splay/Paleosol}

Clay-rich mudstones are the dominant primary facies included in facies association B. While these mudstones were most often found to be featureless, occasional mud cracks, root traces, bleached sand lenses, and thin, continuous sandstone units were observed. Ranging from $15-150 \mathrm{~cm}$ in thickness, this facies association commonly graded upward into the sabkha facies association (A). Units often alternated between increasingly thin, recessive mudstone beds and increasingly thicker and more resistant haloturbated beds exhibiting sand-patch fabric. Figure 34 provides a model stratigraphic column of this facies association. 
Based on the interpretation of the dominant primary facies (i.e. clay-rich mudstones), this facies association was likely deposited in topographic lows, where water was able to pond, and fine-grained sediments settled out. The presence of mud cracks indicates that drying also occurred between periods of standing water. Root traces indicate that plant growth was able to develop in this environment, likely producing soil. Intermittently deposited sands were possibly deposited by low-volume, localized flows that reworked sandy portions of channels. These thin sandstone units were likely bleached by organic material within surrounding mudstone units. While in some locations lower topography is thought to encourage the growth of thicker salt crusts, relatively frequent influx of fresh water may have prevented salt crust development. Periods marked by mud cracks may have occurred more frequently than is recorded in the facies association, but unless the next layer of sediment was sand, more incoming mudstone would simply fill the void spaces with homogenous sediment, thus masking other processes. Facies association B is interpreted as representing channel overbank ponding events (or in locations where flow extended past established channels onto the sabkha) and varying levels of paleosol development in hyper-distal portions of the fluvial system (Figure 35).

\section{Facies Association C-Distal Terminal Splay}

Primary facies grouped into association $\mathrm{C}$ include those found within sandstone sheets. Sandstone sheet units were consistently found to be very well-sorted and only ranged from very fine to lower medium sands, with no clay content, and little silt content. Despite homogeneity within grain size distribution, these units hosted the greatest variety of bedforms and identifiable primary facies within the study interval. An identifiable stacking pattern of primary facies was found within sandstone sheets at every outcrop. This pattern starts with erosional surfaces, progresses from critical to supercritical facies, and ends with climbing ripple and small dune 
facies. The highest energy conditions represented in this facies association (and within the study interval) include basal scours, flute casts, and sinusoidal scours. These were commonly followed by critical flow planar-laminated beds, then by supercritical flow bedforms. These included subplanar lamination (stable antidunes), unstable antidunes, aggrading and climbing antidunes, aggradational chutes and pools, and cyclic steps. Waning flow and rapid sedimentation facies include climbing ripples, mega-ripples, and small dunes. Figure 36 provides a model stratigraphic column of this facies association.

Scoured basal contacts, supercritical flow facies, and waning flow facies are all indicative of specific depositional conditions. The presence of basal scouring suggests that discrete depositional events occurred. These events included initial periods of erosion followed by periods of deposition. Supercritical flow facies indicate a specific set of flow conditions. These conditions and resultant facies have been described in many different settings, ranging from rare cataclysmic events, such as glacial dam outbursts (Lang and Winsemann, 2013; Winsemann et al., 2015), turbidity currents (Hand, 1974; Prave and Duke, 1990; Yagishita, 1994; Wynn et al., 2000; Fildani et al., 2006), pyroclastic flows (Charland and Lajoie, 1989; Schmincke et al., 1973), and rapidly flowing rivers (Langford and Bracken, 1987; Alexander and Fielding, 1997; Fralick, 1999; Fielding, 2006; Alexander, 2008). Small dunes, mega-ripples, and climbing ripples suggest a waning flow, and are common in various depositional environments, including but not limited to deltas (Coleman and Gagliano, 1960; Coleman and Prior, 1982), submarine canyons and fans (Shanmugam, 2003; Kane et al., 2007), and ephemeral streams and alluvial fans (Sneh, 1983; Olsen, 1987; Hill, 1989).

Due to the arid climatic setting and siliciclastic composition of constituent grains, glacial outbursts and pyroclastic flows can be ruled out immediately. Turbidity currents share all of the 
primary facies described for this facies association but would require the accompaniment of marine mudstone facies between depositional events, instead of the many sub-aerial facies that are observed throughout the study interval. This facies association is interpreted to represent an ephemeral, fast-flowing fluvial depositional environment, capable of scouring older sediments, then depositing supercritical bedforms before flow wanes and deposits climbing ripples and dunes. The general lack of channel development, point or mouth bar development, and the wide variability in flow conditions discounts a normal fluvial or deltaic environment. Primary facies observed within this facies association indicate that it was dominated by discrete flow events that included scouring, supercritical, and waning flow conditions. The combination of these flow conditions is typical of dryland fluvial settings, including intermittent or ephemeral flows with high sediment transport and bedload transport rates (Tooth and Nanson, 2011). Facies association $\mathrm{C}$ is interpreted to represent unchannelized (or nearly so) ephemeral stream deposits, where lateral spread was prevalent and resulted in sheet flood sand deposits. These deposits are typical of distal reaches of fluvial terminal splays (Hubert and Hyde, 1982; Lang et al., 2004; Nichols and Fisher, 2007; Fisher et al., 2008; McKie, 2014).

One interval of clean sandstone sheets was found to form a single amalgamated bed over a distance of approximately $15 \mathrm{~m}$, which then separated into 3-4 distinct, inter-fingering, ledgeforming sheets (see Figure 37). Four thickness measurements were taken along strike in order to determine whether there was any change in total thickness of the interval. While the individual sandstone units were found to pinch and swell over tens of meters, measurements of the interval yielded total thicknesses of $203 \mathrm{~cm}, 220 \mathrm{~cm}, 215 \mathrm{~cm}$, and $215 \mathrm{~cm}$ over a distance of $360 \mathrm{~m}$. 


\section{Facies Association D-Hyper-distal terminal splay}

Siltstone and ripple bundle facies make up facies association D. Ripple bundles are found within siltstone slopes, making slight ledges. These ripple bundle ledges typically make up only $10-20 \%$ of this facies association. In some instances, ripple bundles coalesced into ripple beds similar in appearance to those found in sandstone sheets of facies association C. Ripple bundles often contained multiple scoured surfaces, and those that graded into more continuous sandstone sheets were likewise separated by scours. Thinner ripple bundles were often separated by the next bundle by $5-15 \mathrm{~cm}$ of recessive siltstone. It is possible that ripples made up a higher percentage of this facies association, but, due to weathering effects, were indistinguishable from siltstone slopes. Figure 38 provides a model stratigraphic column of this facies association.

This facies association is interpreted to be closely related to facies association $\mathrm{C}$, but resulting from a lower-energy, silt- and mud-rich flow. This is likely achieved by developing in a location farther downstream, after short-lived, high-energy flows have lost much of their energy and coarser sediment load. Benvenuti and Martini (2002) describe sedimentation events in alluvial fans where a turbulent flow transitions from channelized to unchannelized flow, consequently developing a bipartite (divided) flow. The basal division continues to move, but as a hyperconcentrated traction carpet or bedload, which suppresses bedform development. The upper division of the flow becomes relatively sediment poor, and would be capable of producing bedforms (Todd, 1989). Siltstone units hosting sandy ripple bundles may represent such divided flows, where large quantities of sediment are deposited in massive beds, while sediment-poor currents rework some massive muddy surfaces into ripple-laminated bundles. This facies association is thought to develop in hyper-distal locations, where flow exceeds the lateral extent of the terminal splay. 


\section{Facies Succession}

The identification of primary facies aids in the interpretation of the specific flow conditions and sedimentation styles and rates within individual units. Grouping primary facies into facies associations aids in identifying depositional environments. Studying the succession of facies associations within a stratigraphic interval allows for the proper identification of a sedimentary system.

\section{Observations}

Calculation of the volumetric percentage of each facies association per section provides insight into stratigraphic stacking trends across the study area (see

Table 1). Units of the sabkha facies association (A), comprise an average of $66.4 \%$ of each section, while units of overbank splay/paleosol facies association (B), comprise an average of $11.1 \%$ of each section. Units of distal terminal splay facies association (C), comprise an average of $12.3 \%$ of each section, and units of hyper-distal terminal splay facies association (D), comprise an average of $14.2 \%$ of each section. Ash beds make up the smallest volume of each measured section, ranging from $0.3-1.4 \%$, with an average of $0.8 \%$. If facies associations $\mathrm{C}$ and $\mathrm{D}$ are the products of similar depositional environments, that is, ephemeral streams in a fluvial terminal splay, then volumetric percentages may be combined for interpretive purposes. The combined facies associations $\mathrm{C}$ and $\mathrm{D}$ range from $10-24 \%$ of total section volume, with an average volume of $20.2 \%$.

The Cedar Mesa section was measured in the northern-most location of the study area, and exhibited the most variation from the other sections. No ashes were observed above the thick middle sabkha, so the only statistics calculated for this section were facies association percentages. 
The section measured at I-70 yielded only one unit interpreted as facies association $\mathrm{C}$, and even then, it was considered a transitional unit between facies associations $\mathrm{C}$ and $\mathrm{D}$. A poorly exposed bed near the top of the section exhibited light tan-colored sandstone, like many of the other units of facies association $\mathrm{C}$, but no individual facies were recognizable.

\section{Trends}

Only one trend in stacking order was recognized on a unit-to-unit scale. In several locations, including Dutch Flat North and South, overbank splay/paleosol facies interfingered with sabkha facies, and exhibited coarsening-upward trends. Dark mudstones graded into increasingly thicker, lighter-colored, and coarser-grained sabkha facies with multiple repetitions (Figure 39. Coarsening upward succession of facies associations A and B.). This succession probably represents areas that accommodated infrequent ponding events in low-lying areas. Between floods a salt crust developed, which subsequently accommodated windblown sediments. In effect, these cycles represent drying-upwards successions.

Three trends were noted in comparing sections. The first of these is that the majority of units of facies association $\mathrm{C}$ occur in the lower portions of the sections, below the ash bed. At the Green River Cutoff Road, $80.5 \%$ of facies association C occurs below the ash bed. At Moore Road North this figure is 61.6\%, at Dutch Flat North, 90.6\%, and at Dutch Flat South, 100\%. Moore Road South is an outlier, with $36.8 \%$ of facies association $\mathrm{C}$ units occurring below the ash bed. The I-70 section hosted no true units of this facies association.

The second section-scale trend is stronger, and indicates that the majority of units of facies association B occur above the ash bed. At Green River Cutoff Road, 92.9\% occurred above the ash bed; at Moore Road South, this figure is $100 \%$; at Moore Road North, $66.0 \%$; at Dutch Flat North, 87.3\%; at Dutch Flat South, 87.0\%; at I-70 this figure is also $100 \%$. 
The third trend has already been mentioned, the presence of a thick sabkha unit within six of the seven sections. The thicknesses of these uninterrupted units range from 3.5-10.6 m, with an average of $7.5 \mathrm{~m}$. The presence of an age-dated ash bed in each of these units confirms they are time correlative, even if some units represent longer periods of uninterrupted sabkha deposition.

\section{Interpreted Sedimentary System}

Ancient analogs provide insight into the depositional history of preserved strata and the sedimentary system as a whole. The frequency of occurrence of specific primary facies and facies associations indicates how depositional environments may have interacted and shifted through time. Furthermore, facies succession is a direct result of local avulsive processes and regional factors such as climate and tectonics.

Hubert and Hyde (1982) describe an alluvial sandflat-playa system in the Upper Triassic Blomidon redbeds of St Mary's Bay, Nova Scotia. Studied outcrops were divided into playa mudflat sandy mudstone facies (64\%), alluvial fan sandflat facies (25\%), playa lake claystone facies $(10 \%)$, and stream channel sandstone facies (1\%). The Blomidon Formation was deposited in a rift valley within the Fundy Basin, which was located at about $25^{\circ} \mathrm{N}$ latitude at time of deposition (Van Houten, 1977).

Playa mudflat facies are described as being composed of small $(1-2 \mathrm{~cm}$ thick) sandy adhesion ripple lenses exhibiting small-scale cross-lamination, supported by poorly-sorted mudstone matrix. Calcite concretions are present in some units, typically $1-15 \mathrm{~cm}$ in diameter. Graded beds, or terminal alluvial fan/sandflat facies, are divided into six different types. These include sandstones and siltstones exhibiting planar lamination, ripple lamination, and "rippledrift" (climbing ripple) lamination. Basal contacts of these facies range from gradational to 
sharp. Convex-upward ripples are described as being common, attributed to the fluid's high suspended load.

Playa-lake claystone facies are well-sorted, lack adhesion ripples, and exhibit fissile lamination. These facies are interpreted as the result of ponding water on the playa/mudflat surface after a flow event. Claystone beds become thicker and more common up section. This is interpreted as the result of an increase in precipitation (resulting in more standing water), as it occurs independently of interpreted tectonic cycles. Hubert and Hyde (1982) describe the sedimentary system of the Blomidon Formation as an alluvial sandflat-playa system, where seasonal precipitation on the alluvial plain created flash floods, which in turn traveled down alluvial fan channels until they reached sandflats along the playa margin. There, rapid sedimentation occurred as slope decreased to $1^{\circ}$ or less, and sheet flows terminated on the playa.

McKie (2014) describes the Triassic Skagerrak and Smith Bank Formations of the central North Sea as dryland fluvial systems interfingered with playa and sabkha systems. Deposited during the initial phases Pangea, sedimentary systems within the Skagerrak Formation responded predominantly to halokinesis and minibasin development. Additional extensional forces in northwest-southeast and northeast-southwest directions contributed to tortuous basin topography. This affected flow directions of fluvial systems, at times inhibiting the dispersal of coarsergrained fluvial sediments and increasing the dominance of fine-grained flood basin sediments. Paleoclimate changes were recognized as important factors in depositional variability. Increases in precipitation caused perennial fluvial systems to replace ephemeral systems, which also expanded to fill the width of the basin. Intervals recording these wetter periods also host intermittent lacustrine sediments. In addition to effecting changes in the lateral extent and type of 
fluvial systems, increasingly humid climate conditions are thought to have provided more fresh water to flora and fauna, significantly increasing observed bioturbation.

McKie (2014) divides the succession into four facies associations, including dry playa, wet playa, terminal splay deposits, and unconfined to weakly confined fluvial deposits. Dry playa facies include heterolithic units of alternating mudstone and fine-grained sandstone. Wave and current-ripple lamination, soft sediment deformation, desiccation fabrics, adhesion ripples, and salt crust fabrics are common. In several cores massive, homogeneous siltstones and very fine sandstones are present, with indistinct wispy lamination as the only visible sedimentary structures. Massive siltstones are found separated by thin $(\sim 10 \mathrm{~cm})$ beds of ripple laminated finegrained sandstones. Wet playa facies are dominated by deformed, irregularly laminated muddy sandstone facies, hosting adhesion lamination and salt crust structures. Units less than $1 \mathrm{~m}$ thick of laminated mudstone, cross-stratified sandstone, indistinct or structureless sandstones and isolated sandstone cross-sets occur sporadically. These units are interpreted to be the result of ponding, small eolian dune migration, and reworking of eolian sediments during flooding or stream flow across the playa.

Terminal splay facies consist of fine-grained sandstones interbedded with ripple laminated or structureless mudstones hosting mud cracks. Sandstones typically have sharp basal contacts, with some mud clasts, and grade upwards into planar laminated and climbing ripple laminated facies. These facies are interpreted to represent shallow, unconfined flows with high sediment loads. Sharp basal contacts indicate flow over sub-aerially exposed surfaces while the rare gradational basal contact represents stream flow into ephemeral standing bodies of water. Fluvial facies include isolated, sharp or erosionally-based channels with abundant mud clast lags. Scours and gutter casts are common, and grade upwards into sub-planar lamination and climbing 
ripple lamination. The lack of channel stacking indicates that channels experienced frequent avulsion, and the abundance of mud clast lags suggests overbank muds or in-channel mud drapes were reworked by subsequent flows. McKie (2014) interprets these facies to represent higher energy deposits, dominated by ephemeral flood processes, than those of the terminal splay facies.

Modern analogs offer insight on a finer scale than that gained through the rock record. Modern systems may be observed in real-time, allowing study of individual depositional events. This allows short-lived, poorly preserved processes to be observed and incorporated into depositional models.

Central Australia hosts numerous playa lakes fed by dryland fluvial systems. The largest of these systems is Lake Eyre and its associated drainage basin, which covers one-sixth of the Australian continent, or 1,140,000 $\mathrm{km}^{2}$ (Lang et al., 2004). Arid climate conditions combine with long transport distances to create otherwise rare conditions where fluvial systems meet playa shorelines. With high evaporation rates and low precipitation rates, fluvial channels and playa lakebeds are typically dry. Rare storm events bring rains and stream flow, such as the February 2003 flooding event described by Payenberg et al., 2004. Previous to this event, Lake Eyre and catchment fluvial channels had remained dry for two years. With precipitation events being rare, and fluvial transport distances being large, lake filling and fluvial channel flow are out of phase; typically, if a precipitation event is occurring over one part of the catchment area, other fluvial systems, as well as the lake bed, are likely to be dry. As a result, stream flow that eventually finds its way to the lake bed finds no water upon arrival. The stream flows across a dry alluvial fan and onto the dry playa surface. Streams typically lose water to a depressed water table in arid settings, and discharge decreases as floods move downstream (Nichols and Fisher, 2007). Stream flow widens upon reaching the flat topography of the playa, and quickly transitions from 
confined channel flow at the lake shore, to poorly confined and unconfined as it filters through distributary bifurcations (Fisher et al., 2008). The resulting sandstone sheets, deposited in a fan shape, are referred to as terminal splays (Lang et al., 2004; Nichols and Fisher, 2007). In locations where terminal splay lobes are inactive, salt crust develops, which alters upper-most sedimentary units, and begins entrapment of windblown sediments.

Lang et al. (2004) describe sedimentary features observed in a series of trenches dug throughout the Neales Creek terminal splay, Lake Eyre, Australia. Proximal, medial, and distal facies were recognized. Proximal facies included trough-cross stratified sandstone, unspecified convex-upward bedforms, sharp basal contacts which were sometimes erosional, and gravel lags. Sandstone units were $0.5-1 \mathrm{~m}$ thick, with little to no mud. Medial facies were dominated by smaller ripples in ripple-laminated units, and sandstone units were thinner than comparable proximal units. Some mud-rich units were found interspersed with sandstones, and contacts were sharp to gradational. Distal facies were observed to contain more than $50 \%$ mud, with thin $(\sim 1-5$ $\mathrm{cm})$, continuous, lensoidal, or disturbed sandstone units. These sandstone units hosted small ripples and planar laminations. Basal contacts were described as gradational, with some sharp contacts.

Fisher et al. (2008) describe sedimentary features observed in a series of trenches dug throughout the Douglas Creek terminal splay, in Lake Eyre, Australia, and divide it into proximal and distal zones. Proximal facies include planar-based, trough cross-stratified, and massive sandstones, which tend to have erosive basal contacts and mud clast or gravel lags. Distal facies include planar-based beds of sandy clay and alternating units of massive sand and clay. The authors note that the transition between the two zones indicates a change from bedload to suspended load-dominated deposition. 
The study interval records the historical presence of sabkha, paleosol/overbank splay, and distal to hyper-distal terminal splay environments. While erosional surfaces are commonly found in the distal terminal splay facies association, no significant unconformable surfaces were recognized. The three primary depositional environments certainly present a variety of flow and sedimentary conditions, but the rapid alternation of environments with no major unconformable surfaces suggests that all three depositional environments were active within the study area simultaneously. The upper Entrada Sandstone exposed within the San Rafael Swell is interpreted to have been formed by fluvial terminal splay that terminated onto an inland sabkha.

\section{Implications from Analogs and Observations}

Facies descriptions from the Blomidon and Skagerrak formations are similar to those observed in the upper Entrada Sandstone. Facies associations and succession interpretations demonstrate many similarities as well. Volumetric percentages of facies associations within the Blomidon Formation are strikingly similar to those calculated for the Entrada (see Table 1). Outcrop percentages for the Entrada are $66.4 \%$ sabkha facies association, $20.2 \%$ terminal splay facies association, and 11.1\% overbank/paleosol facies association; Blomidon outcrop percentages are $64 \%, 25 \%$, and $10 \%$ for the equivalent facies, respectively. The Skagerrak Formation demonstrates similarly analogous associations and successions. While less-detailed descriptions of this formation are available due to data sources being restricted to well and core data, McKie's work on the Skagerrak Formation provides insight into the regional parameters that affected the development of that system through time, including climate and tectonic processes. While no clear indications of climate change were observed in the upper Entrada (such as a change in fluvial style or increase in bioturbation), tectonic processes may explain the primary changes in facies dominance throughout the study interval. 
The three facies succession trends observed within the upper Entrada represent three distinct periods of time during which different depositional environments either dominated or were at least more common. These changes in environment can be interpreted as progradation or retrogradation of a terminal splay system over a sabkha.

The first interval includes frequent occurrences of poorly confined to unconfined ephemeral stream deposits. This represents the distal zone within a terminal splay, which happens to be the most proximal part of a terminal splay preserved and exposed within the study area. The next interval is marked by a clear dominance of sabkha facies. This suggests that for that interval, little to no fluvial influence was felt, or at least preserved, at this location. This suggests a setting well within the sabkha extent. The third and youngest interval hosts most of the low topography ponding or paleosol environments observed within the study interval. This suggests that while fluvial influence was felt during this time, it was restricted to locations in a terminal splay system where flow ended, and settling, ponding, and drying of fine-grained sediments occurred. Such environments include overbank splays and ponding surfaces at the boundary of the terminal splay and open sabkha. This environment represents the most distal part of a terminal splay system (hyper-distal). A regional cross-sectional diagram of the sedimentary system is presented in Figure 40.

\section{Drivers}

McKie (2014), offers possible allogenic factors, such as tectonic and climatic regimes, as important drivers that may have inhibited or encouraged flow of fluvial systems. The distinct intervals observed in the upper Entrada may be the result of tectonic controls on the hinterland sediment source and foreland trough wherein deposition is occurring. Uplift of the hinterlands typically causes increased erosion rates and an increase in sediment supply, which may have 
stimulated an advance of fluvial sediment across the basin. Conversely, tectonic loading of the crust during orogenic events can cause a foredeep to deepen, creating more accommodation closer to the hinterlands, causing a retreat of fluvial systems and their sediments across a basin. McKie (2014) suggests that climatic changes not only affected facies migration, but also determined whether perennial or ephemeral streams dominated the fluvial system.

Another possibility is that apparent progradation and retrogradation of the terminal splay system is the result of autogenic avulsions of terminal splay lobes, such as those described by Nichols and Fisher (2007) and observed in satellite imagery of Lake Frome (Figure 41). Sabkhas create some of the flattest surfaces on Earth, and thus experience unique avulsion processes, compared to other systems with greater slopes. Fluvial channels typically incise underlying sediments or bedrock due to differences in elevation between upstream and downstream locations (downcutting). In a setting with little to no slope and sediment-rich, ephemeral stream flow, little to no downcutting or reworking of previous-lain sediment occurs. Under such conditions, channels are not easily developed, and unconfined flow may dominate. As one flow ends, sediment is deposited, and in such a flat setting, even modest accumulation of this sediment creates an elevational obstacle to future flows (Tunbridge, 1984). In this way, distal portions of a terminal splay can only host a very limited number of flows before accumulating enough sediment to become new high ground. Thus, flow pathways are choked, and the number of avulsion events are high compared to the number of flow events. Data from this study supported this interpretation of low topography, and the lack of clear unit-to-unit trends in succession supports the idea of rapid avulsion. One flow event may deposit medial to distal terminal splay facies sandstones, immediately followed by long periods of time with no fluvial interaction whatsoever. Sabkha facies may then prevail until an overbank splay or terminal pond develops 
over the area in a single flooding event. In this way, fining upward or coarsening upward trends, which are often associated with progradation or retrogradation of sedimentary systems, may be absent. A terminal splay avulsion model is proposed in Figure 42. The exceptional preservation of bedforms is likely a direct result of frequent avulsion (in addition to high sedimentation rates), where nearly every flow event is also an avulsive event, resulting in almost no reworking of previously laid sediments. This possibility is supported by the rarity of scoured surfaces and general lack of significant unconformities.

\section{CONCLUSIONS}

The primary objectives of this study were to identify sedimentary structures found within the upper Entrada Sandstone of central Utah, and to place them in context within a sedimentary system. Careful observation and identification of sedimentary structures provided important details about flow conditions such as criticality and sediment load. Outcrop exposures were studied and divided into primary facies, facies assemblages, and facies successions. Primary facies provided details regarding specific sedimentary events, and facies assemblages provided details regarding depositional environments. Facies successions provided insight into groups of depositional events, and how one depositional environment transitioned to another. The lateral distribution of facies provided additional insight into the ancient topography, which also helped to constrain the depositional setting. Comparing findings from this study to those of other locations yielded convincing analogs, which served to confirm the validity of the interpreted sedimentary system.

\section{New Interpretations}

Early descriptions of the Entrada Sandstone cite laterally continuous beds as evidence for a marine depositional environment. Later studies cited the thin and rapidly alternating 
characteristics of units as evidence of tidal flat environments. This study used these observations, coupled with finer details, to reinterpret the depositional environment of the upper Entrada Sandstone. The dominance of sabkha sediments within the study interval indicates an extremely flat and arid paleogeographic setting. The flow direction of the rest of the constituent units is almost exclusively east to west, ruling out bidirectional tidal currents. Flat topography and high sediment loads resulted in frequent avulsion of fluvial terminal splays, which produced the laterally extensive, alternating beds of sabkha and terminal splay sediments characteristic of the upper Entrada Sandstone.

Ultimately, the presence of hummocky cross-stratification within the study area was ruled out, but it is important to note that other authors have addressed the common confusion of hummocky cross-stratification and antidunes in marine and fluvial settings (Prave and Duke, 1990; Rust and Gibling, 1990). In addition, convex-upward bedforms in sandy units were consistently observed in modern and ancient analogs, suggesting that antidunes may be more common to this type of depositional setting than previously acknowledged. As this study progressed, it became clear that accurate interpretation of sedimentary features and primary facies was greatly facilitated by studying features in context, in terms of associated features, facies, and successions. As one observed feature after another was identified as resulting from a terrestrial depositional environment, possible settings that could have also produced the remaining features narrowed. This led to a small set of possible sedimentary system analogs described as hosting the same set of features and characteristics. The unique set of shared features between the upper Entrada and Blomidon and Skagerrak Formations, as well as Lakes Eyre and Frome, provide support for the sedimentary system interpretation. 
The preservation of supercritical bedforms such as antidunes not only reveals important flow conditions, but also signals a specific location within the sedimentary system. The relatively fine-grained sediment and lack of significant unconformable surfaces (as evidenced by very limited erosion) suggests that flow energy was not exceptionally high. In order to achieve supercriticality in relatively low energy conditions, flow must have been shallow. The rarity of identifiable channel edges indicate that these sediments were deposited during unchannelized flow. As flow widened and shallowed upon surpassing the channel extent, velocity also would have decreased. Under these conditions, supercritical flow would only have a chance to develop at the moment when flow became unchannelized, but before it spread out so far across the ground that it slowed down significantly. In this way, supercritical bedforms formed when flow depth decreased faster than flow velocity, most likely marking the precise point on the terminal splay-sabkha margin where channels ended and sheet flow began. Frequent avulsion events directing most flooding events to new paths over sabkha or overbank splay/paleosol surfaces may have also contributed to the development of supercritical flow. Salt encrusted and finegrained surfaces would have likely allowed very little infiltration of stream flow, in turn allowing flow to maintain a higher velocity while spreading and shallowing.

\section{Sedimentary System}

The upper Entrada represents an interfingered sabkha and fluvial terminal splay system

(Figure 43). These are marked by a wide array of sedimentary structures, representing an equally wide array of depositional conditions. The ancient environment of the upper Entrada Sandstone in central Utah represents stark extremes, from extremely dry to flash flooding conditions. During arid conditions, the only source of water was evaporative pumping of a high water table. During the rare occasions when surface water flowed through the system, extreme flooding 
events produced high-criticality flow conditions including evidence of the highest stages of supercritical flow. Waning flow conditions followed, producing climbing ripple sets and leaving shallow ponds of water in topographic lows, where rapid drying or short-lived plant growth occurred.

During sabkha-dominated periods, the lack of fluvial input allowed salt crusts to develop which captured wind-blown sediments transported by northeastern winds from the erg to the east. These periods are represented by approximately $66 \%$ of the upper Entrada by volume. The low-energy nature of these periods is underlined by the preservation of ash beds, which are only found within sabkha intervals. This suggests that the environment lacked any effective erosional processes. Fluvial terminal splay deposits represent depositional events where sedimentation occurred rapidly and for short periods of time. These periods make up approximately $20 \%$ of the upper Entrada by volume. Despite such high-energy flood conditions, relatively little erosion occurred. Each event deposited sufficient quantities of sediment to dam flow paths, causing rapid and active avulsion of terminal splay lobes. The remaining $14 \%$ of outcrop volume represents overbank flood sediments or paleosols, with a small percentage $(<3 \%)$ representing ash beds or uncategorized units. Topographic lows that experienced flooding accommodated fine-grained siliciclastics. These clays and silts were then disturbed through desiccation as surfaces experienced complete drying. In other locations, humid conditions persisted long enough to support plant growth. These facies represent transitional periods between fluvial input and a return to evaporation-dominated processes found in a sabkha setting.

\section{Allogenic vs. Autogenic Processes}

While it remains difficult to piece together the structural history of long-eroded orogenic belts, sedimentary systems deposited in adjacent basins offer important insight into tectonic 
trends. The upper Entrada Sandstone offers such insight into the history of the Elko Fold Belt. During periods of active uplift, sedimentation rates would likely have increased due to greater slope as well as possible increases in monsoonal intensity, which would have resulted from higher orogenic barriers to humid air masses. Either of these factors could have resulted in a progradation of fluvial systems into the foreland basin. At maximum uplift, crustal loading may have deepened the basin, creating more accommodation. Greater basinal accommodation could have limited or reversed fluvial progradation. A retreat of fluvial systems would have allowed sabkha processes to dominate, which may explain the thick sabkha interval of the middle Entrada and thinner but still significant sabkha intervals within the upper Entrada. The three general trends identified at a section scale mark pro- and retrogradations of terminal splays onto the sabkha. Following the middle Entrada sabkha interval which bears no record of fluvial influence, the upper Entrada begins with the rapid progradation of terminal splays to a distal or even medial zone. Retrogradation follows, where little to no terminal splay sediments are present and thick sabkha units dominate. The top of the Entrada is marked by a reappearance of terminal splay sediments, this time predominantly as hyper-distal zone deposits, including overbank splays or terminal pond paleosols and shales.

These processes provide possible explanations as to why certain intervals within the study area are dominated by sabkha or terminal splay deposits. While important trends in allogenic processes may be interpreted from the sedimentary record, it is important to recognize that in locations with low topographic relief, autogenic processes exert a strong influence on facies distribution, including avulsive migration of the fluvial system across the sabkha margin. Frequent avulsion of terminal splay lobes, coupled with pro- and retrogradation of the fluvial 
terminal splay system, produced the distinct interfingering of sabkha and fluvial terminal splay sediments found in central Utah's upper Entrada Sandstone. 


\section{REFERENCES}

Alexander, J., 2008, Bedforms in Froude-supercritical flow: Sedimentology, Marine and River Dune Dynamics, no. 48, p. 133-152.

Alexander J., and Fielding, C., 1997, Gravel antidunes in the tropical Burdekin River, Queensland, Australia: Sedimentology, v. 44, is. 2, p. 327-337.

Ashley, G. M., Southard, J. B., and Boothroyd, J. C., 1982, Deposition of climbing-ripple beds: a flume simulation: Sedimentology, v. 29, is. 1, p. 67-79.

Benvenuti, M., and Martini, I. P., 2002, Analysis of terrestrial hyperconcentrated flows and their deposits: Flood and Megaflood Processes and Deposits: Recent and Ancient Examples: ed. Martini, I. P., Baker, V. R., and Garzón, G., International Association of Sedimentologists, Special Publication, v. 32, p. 167-193.

Blakey, R. C., Peterson, F. Caputo, M. V., Geesaman, R. C., and Voorhees, B. J., 1983, Paleogeography of Middle Jurassic Continental, Shoreline, and Shallow Marine Sedimentation, Southern Utah: Mesozoic Paleogeography of the West-Central United States: Rocky Mountain Symposium 2, p. 77-100.

Blakey, R. C., Peterson, F., and Kocurek, G., 1988, Synthesis of late Paleozoic and Mesozoic eolian deposits of the Western Interior of the United States: Sedimentary Geology, v. 56, is. $1-4$, p. $3-125$.

Bourgeois, J., 1980, A transgressive shelf sequence exhibiting hummocky cross-stratification: The Cape Sebastian Sandstone (Upper Cretaceous), south-western Oregon: Journal of Sedimentary Petrology, v. 50, p. 681-702.

Burchfiel, B. C., and Davis, G. A., 1975, Nature and controls of cordilleran orogenesis, Western United Stats: Extensions of an earlier synthesis: American Journal of Science, v. 275-A, p. 363-396.

Carr-Crabaugh, M., and Kocurek, G., 1998, Continental sequence stratigraphy of a wet eolian system; a key to relative sea-level change: Society for Sedimentary Geology Special Publication, v. 59, p. 213-228. 
Cartigny, M. J. B., Ventra, D., Postma, G., and Van Den Berg, J. H., 2013, Morphodynamics and sedimentary structures of bedforms under supercritical-flow conditions: New insights from flume experiments: Sedimentology, v. 61, is. 3, p. 712-748.

Charland, A., and Lajoie, J., 1989, Characteristics of pyroclastic deposits at the margin of Fond Canonville, Martinique, and implications for the transport of the 1902 nuées ardentes of Mt. Pelée: Journal of Volcanology and Geothermal Research, v. 38, is. 1-2, p. 97-112.

Chow, V. T., 1959, Open-Channel Hydraulics: MacGraw-Hill Book Co. Inc., New York, NY, p. 206.

Coleman, J. M., and Gagliano, S. M., 1960, Sedimentary Structures : Mississippi River Deltaic Plain : SEPM Special Publication 12: Primary Sedimentary Structures, p. 133-148.

Coleman, J. M., and Prior, D. B., 1982, Deltaic Environments of Deposition, in Sandstone Depositional Environments: AAPG Special Publication: Memoir, p. 139-178.

Coney, P., 1976, Plate tectonics and the Laramide orogeny: N.M. Geological Society Special Publication, v. 6, p. 5-10.

Cook, P., 2016, Sedimentology and Stratigraphy of the Middle Jurassic Preuss Sandstone in Northern Utah and Eastern Idaho [Master's Thesis]: Brigham Young University.

Christiansen, E. H., Kowallis, B. J., and Barton, M. D., 1994, Temporal and spatial distribution of volcanic ash in Mesozoic sedimentary rocks of the Western Interior: An alternative record of Mesozoic magmatism, in Caputo, M. V., Peterson, J. A., and Franczyk, K. J., eds., Mesozoic systems of the Rocky Mountain region, USA: Denver, Colorado, Rocky Mountain Section, SEPM, p. 73-94.

Crabaugh, M., and Kocurek, G., 1993, Entrada Sandstone: an example of a wet Aeolian system: London Geological Society, Special Publications, v. 72, p. 103-126.

Cross, W., 1907, Stratigraphic results of a reconnaissance in western Colorado and eastern Utah: Geology, v. 15, p. 641.

Dake, C. L., 1919, The horizon of the marine Jurassic of Utah: Geology, v. 27, p. 634-646. 
DeCelles, P.G., 2004. Late Jurassic to Eocene evolution of the Cordilleran thrust belt and foreland basin system, western U.S.A.: American Journal of Science, v. 304, p. 105-168.

Dickinson, W.R., 1976, Sedimentary basins developed during evolution of Mesozoic-Cenozoic arc-trench system in western North America: Canadian Journal of Earth Sciences, v. 13, no. 9 , p. 1268-1287.

Dossett, T. S., 2014, The First 40Ar/39Ar Ages and Tephrochronologic Framework for the Jurassic Entrada Sandstone in central Utah [Master's Thesis]: Brigham Young University: All Theses and Dissertations, Paper 5315.

Dott, R.H., Jr., and Bourgeois, J., 1982, Hummocky stratification: significance of its variable bedding sequences: GSA Bulletin, v. 93, p. 663-680.

Emery, W. B., 1918, The Green River Desert section Utah: American Journal of Science, ser. 4, v. 46, p. $551-577$.

Fielding, C. R., 2006, Upper flow regime sheets, lenses and scour fills: Extending the range of architectural elements for fluvial sediment bodies: Sedimentary Geology, v. 190, is. 1-4, p. $227-240$.

Fildani, A., Normark, W. R., Kostic, S., and Parker, G., 2006, Channel formation by flow stripping: large-scale scour features along the Monterey East Channel and their relation to sediment waves: Sedimentology, v. 53, is. 6, p. 1256-1287.

Fisher, J. A., Krapf, C. B. E., Lang, S. C., Nichols, G. J., and Payenberg, T. H. D., 2008, Sedimentology and architecture of the Douglas Creek terminal splay, Lake Eyre, central Australia: Sedimentology, v. 55, is. 6, p. 1915-1930.

Fralick, P., 1999, Paleohydraulics of chute-and-pool structures in a Paleoproterozoic fluvial sandstone: Sedimentary Geology, v. 125, is. 3-4, p. 129-134.

Gilluly, J., and Reeside, J. B., 1928, Sedimentary Rocks of the San Rafael Swell and Some Adjacent Areas in Eastern Utah: USGS Shorter Contributions to General Geology, Professional Paper, no. 150, p. 61-110. 
Goodall, T. M., North, C. P., and Glennie, K. W., 2000, Surface and subsurface sedimentary structures produced by salt crusts: Sedimentology, v. 47, is. 1, p. 99-118.

Hand, B. M., 1974, Supercritical Flow in Density Currents: SEPM, v. 44, no. 3, p. 637-648.

Harms, J. C., Southard, J. B., Spearing, D. R., and Walker, R. G., 1975, Depositional environments as interpreted from primary sedimentary structures and stratification sequences: SEPM Course Notes, no. 2, p. 161.

Hicks, T. C., Morris, T. H., and Fairbanks, M. D., 2010, Facies Analysis of the Transitions Between Subtidal, Intertidal, and Supratidal Zones of the Entrada Sandstone, SouthCentral Utah: A Provisional Sequence Stratigraphic Analysis: Utah Geological Association: Geology of South Central Utah, p. 317-337.

Hicks, T. C., 2011, Facies Analysis and Reservoir Characterization of Subtidal, Intertidal, and Supratidal Zones of the Mudstone-rich Entrada Sandstone, South-Central Utah [Master's Thesis]: Brigham Young University.

Hill, G., 1989, Distal alluvial fan sediments from the Upper Jurassic of Portugal: controls on their cyclicity and channel formation: Journal of the Geological Society, v. 146, p. 539555.

Hubert, J. F., and Hyde, M. G., 1982, Sheet-flow deposits of graded beds and mudstones on an alluvial sandflat-playa system: Upper Triassic Blomidon redbeds, St Mary’s Bay, Nova Scotia: Sedimentology, v. 29, is. 4, p. 457-474.

Imlay, R. W., 1952, Marine origin of Preuss Sandstone of Idaho, Wyoming, and Utah: AAPG Bulletin, v. 36, p. 1735-1753.

Jennings, G.R., 2014, Facies Analysis, Sequence Stratigraphy and Paleogeography of the Middle Jurassic (Callovian) Entrada Sandstone: Traps, Tectonics, and Analogue [Master's thesis]: Brigham Young University.

Kane, I. A., Kneller, B. C., Dykstra, M., Kassem, A., and McCaffrey, W. D., 2007, Anatomy of a submarine channel-levee: An example from Upper Cretaceous slope sediments, Rosario Formation, Baja California, Mexico: Marine and Petroleum Geology, v. 24, is. 6-9, p. 540-563. 
Kocurek, G., and Dott, R., 1983, Jurassic Paleogeography and Paleoclimate of the central and Southern Rocky Mountains Region, in Reynolds, M. W. and E. D. Dolly, eds., Mesozoic Paleogeography of the West-Central United States: Rocky Mountain Symposium 2, Denver, Colorado, Society for Sedimentary Geology: Rocky Mountain Section, p. 101116.

Langford, R., and Bracken, B., 1987, Medano Creek, Colorado, a Model for Upper-FlowRegime Fluvial Deposition: SEPM, v. 57, no. 5, p. 863-870.

Lang, S. C., Payenberg, T. H. D., Reilly, M. R. W., Hicks, T., Benson, J. and Kassan, J., 2004, Modern Analogues for dryland sandy fluvial-lacustrine deltas and terminal splay reservoirs: Aust. Petrol. Prod. Explor. Assoc. J., v. 44, p. 329-356.

Lang, J., and Winsemann J., 2013, Lateral and vertical facies relationships of bedforms deposited by aggrading supercritical flows: From cyclic steps to humpback dunes: Sedimentary Geology, v. 296, p. 36-54.

Longwell, C. R., Miser, H. D., Moore, R. C., Bryan, K., and Paige, S., 1923, Rock formations of the Colorado Plateau in southern Utah and northern Arizona: USGS Professional Paper, no. 132 , p. $1-23$.

Lowe, D., 2010, Tephrochronology and its application: a review: Quaternary Geochronology, v. 6, p. $107-153$.

Lupton, C. T., 1916, Geology and coal resources of Castle Valley in Carbon, Emery, and Sevier Counties, Utah: USGS Bulletin, no. 628, p. 19-26.

Makechnie, G.K., 2010, Sequence Stratigraphic Analysis of Marginal Marine Sabkha Facies: Entrada Sandstone, Four Corners Region [Master's Thesis]: University of Texas at Austin.

Mariño, J. E., and Morris, T. H., 1996, Erg Margin and Marginal Marine Facies Analysis of the Entrada Sandstone, Utah: Implications to Depositional Models and Hydrocarbon Entrapment: The Continental Jurassic, Michael Morales, Museum of Northern Arizona Bulletin, no. 60, p. 483-496. 
McKie, T., 2014, Climatic and tectonic controls on Triassic dryland terminal fluvial system architecture, central North Sea: International Association of Sedimentologists Special Publication, v. 46, p. 19-58.

Morris, T. H., Spiel, K. B., Cook, P. S., and Bonner, H. M., 2016, Landscapes of Utah's Geologic Past: Provo, BYU Press, 2016, 80 p.

Nichols, G. J., and Fisher, J. A., 2007, Processes, facies and architecture of fluvial distributary system deposits: Sedimentary Geology, v. 195, is. 1-2, p. 75-90.

Olsen, H., 1987, Ancient ephemeral stream deposits: a local terminal fan model from the Bunter Sandstone Formation (L. Triassic) in the Tønder-3, -4 and -5 wells, Denmark: London Geological Society Special Publications, v. 35, p. 69-86.

Payenberg, T. H. D., Reilly, M. R. W., Lang, S. C., and Kassan, J., 2004, Sedimentary processes in an ephemeral river and terminal splay complex, Lake Eyre, Central Australia observation from the February 2003 flooding event: Sandstone Deposition in lacustrine Environments: Implications for Exploration and Reservoir Development: 2004 AAPG Hedberg Conference Abstract, p. 1-4.

Peterson, F., 1994, Sand Dunes, Sabkhas, Streams, and shallow Seas: Jurassic paleogeography in the Southern part of the Western Interior Basin: SEPM Rocky Mountain Section, Mesozoic Systems of the Rocky Mountain Region, USA, p. 233-272.

Pett J. W., and Walker, R. G., 1971, Relationship of Flute Cast Morphology to Internal Sedimentary Structures in Turbidites: Journal of Sedimentary Petrology, v. 41, no. 1, p. $114-128$.

Perkes, T. L., 2010, Integrating Facies Analysis, Terrestrial Sequence Stratigraphy, and the First Detrital Zircon (U-Pb) Ages of the Twist Gulch Formation, Utah, USA: Constraining Paleogeography and Chronostratigraphy [Master's thesis]: Brigham Young University.

Prave, A. R., and Duke, W. L., 1990, Small-scale hummocky cross-stratification in turbidites: a form of antidune stratification?: Sedimentology, v. 37, is. 3, p. 531-539.

Prentice, J. E., 1956, The interpretation of flow-markings and load-casts: Geological Magazine, is. 93.5 , p. $393-400$. 
Quin, J. G., 2011, Is most hummocky cross-stratification formed by large-scale ripples?: Sedimentology, v. 58, p. 1414-1433.

Roen, J. B., and Hosterman, J. W., 1982, Misuse of the term "bentonite" for ash beds of Devonian age in the Appalachian basin: GSA Bulletin, v. 93, no. 9, p. 921-925.

Rust, B. R., and Gibling, M. R., 1990, Three-Dimensional Antidunes as HCS Mimics in a Fluvial Sandstone: The Pennsylvanian South Bar Formation Near Sydney, Nova Scotia: Journal of Sedimentary Petrology, v. 60, no. 4, p. 540-548.

Schmincke, H., Fisher, R. V., and Waters, A. C., 1973, Antidune and chute and pool structures in the base surge deposits of the Laacher See area, Germany: Sedimentology, v. 20, is. 4, p. 553-574.

Shanmugam, G., 2003, Deep-marine tidal bottom currents and their reworked sands in modern and ancient submarine canyons: Marine and Petroleum Geology, v. 20, is. 5, p. 471-491.

Smith, L. S., 1976, Paleoenironments of the Upper Entrada Sandstone and Curtis Formation on the west flank of the San Rafael swell, Emery County, Utah [Master's Thesis]: Brigham Young University.

Smoot, J. P., and Castens-Seidell, B., 1994, Sedimentary Features Produced by Efflorescent Salt Crusts, Saline Valley and Death Valley, California, Sedimentology and Geochemistry of Modern and Ancient Saline Lakes, SEPM Special Publication No. 50, p. 73-90.

Sneh, A., 1983, Desert Stream Sequences in the Sinai Peninsula: Sedimentary Petrology, v. 53, no. 4 , p. 1271-1279.

Steiner, M.B., 1983, Mesozoic Apparent Polar Wander and Plate Motions of North America: Mesozoic Paleogeography of the West-Central United States: Rocky Mountain Symposium 2, p. 1-11.

Stokes, W. L., 1980, Stratigraphic interpretations of Triassic and Jurassic Beds, Henry Mountains Area: Henry Mountains Symposium, Utah Geological Association, p. 113122. 
Todd, S. P., 1989, Stream-driven, high-density gravelly traction carpets: possible deposits in the Trabeg Conglomerate Formation, SW Ireland and some theoretical considerations of their origin: Sedimentology, v. 36, is. 4, p. 513-530.

Tooth, S., and Nanson, G. C., 2011, Distinctiveness and Diversity of Arid Zone River Systems, in Thomas, D. S. G., ed., Arid Zone Geomorphology: Process, Form and Change in Drylands: Published Online, John Wiley \& Sons, $3^{\text {rd }}$ ed..

Tunbridge, I. P., 1984, Facies model for a sandy ephemeral stream and clay playa complex; the Middle Devonian Trentishoe Formation of North Devon, U.K.: Sedimentology, v. 31, p. $697-715$.

Van Houten, F. B., 1977, Triassic-Liassic deposits of Morocco and eastern North America: comparison: AAPG Bulletin, v. 61, p. 79-99.

Winsemann, J., Alho, P., Laamanen, L., Goseberg, N., Lang, J., and Klostermann, J., 2015, Flow dynamics, sedimentation and erosion of glacial lake outburst floods along the Middle Pleistocene Scandinavian Ice Sheet (northern central Europe): Boreas, v. 45, is. 2, p. 260 283.

Wise, E. M., Semeniuk, T. A., Bruintjes, R., Martin, S. T., Russell, L. M., and Buseck, P. R., 2007, Hygroscopic behavior of NaCl-bearing natural aerosol particles using environmental transmission electron microscopy: Journal of Geophysical Research, v. 112, no. D10224, p. 1-12.

Wynn, R. B., Weaver, P. P. E., Ercilla, G., Stow, D. A. V., and Masson, D. G., 2000, Sedimentary processes in the Selvage sediment-wave field, NE Atlantic: new insights into the formation of sediment waves by turbidity currents: Sedimentology, v. 47, is. 6, p. 1181-1197.

Yagishita, K., 1994, Antidunes and Traction-Carpet Deposits in Deep-Water Channel Sandstones, Cretaceous, British Columbia, Canada: Journal of Sedimentary Research, v. 64A, no. 1, p. 34-41. 


\section{FIGURES}

Figure 1. Paleogeography of Utah during Middle Jurassic Callovian time............................... 58

Figure 2. Paleogeography of the central Rockies during Middle Jurassic Callovian time........... 59

Figure 3. Locations of measured sections along the western flank of the San Rafael Swell........ 60

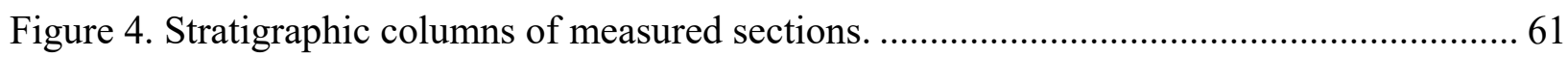

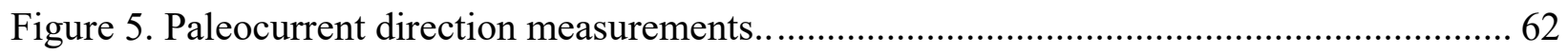

Figure 6. Paleocurrent direction mean average vectors............................................................... 63

Figure 7. Paleocurrent direction mean average vectors for each measured section. .................... 64

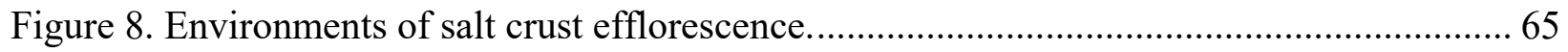

Figure 9. Wispy lamination and irregular sand lenses or "sand-patch" fabric. .............................. 65

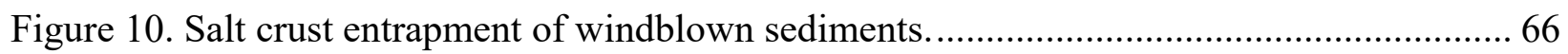

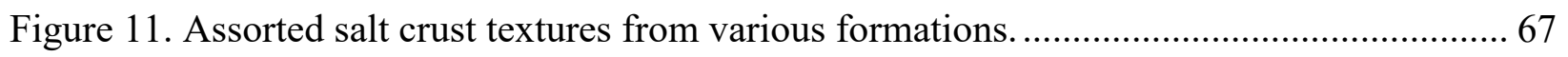

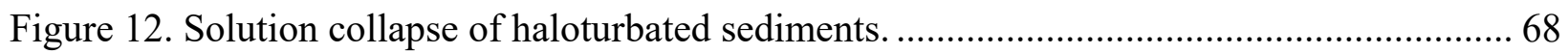

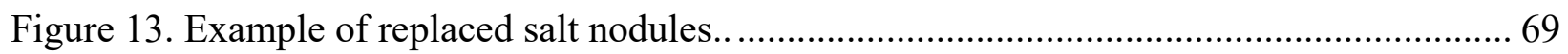

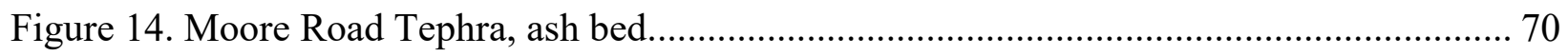

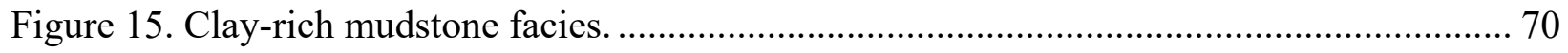

Figure 16. Thin sandstone lenses and continuous sandstone units........................................... 71

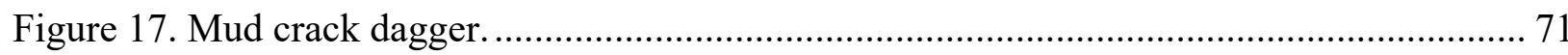

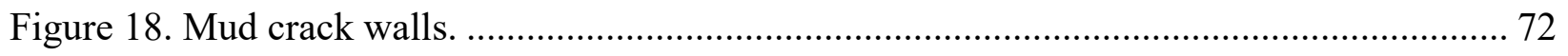

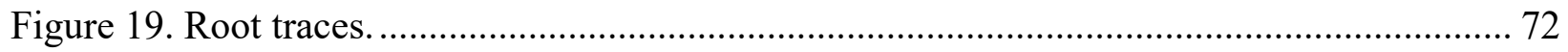

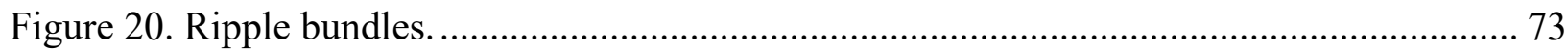

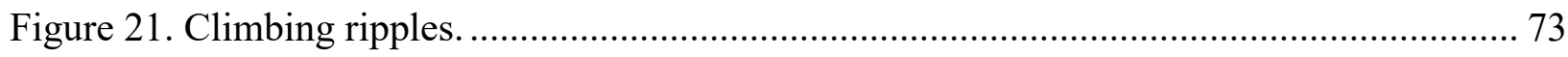

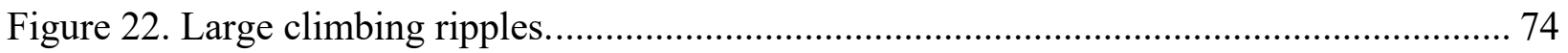




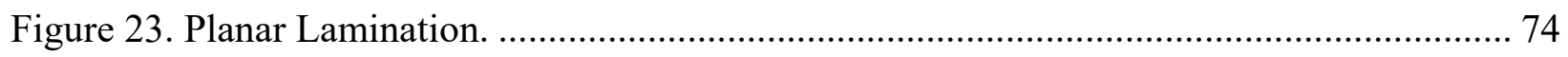

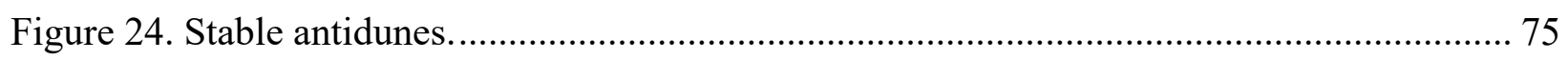

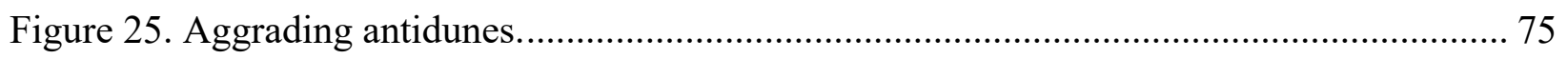

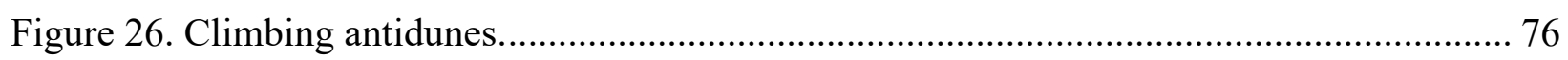

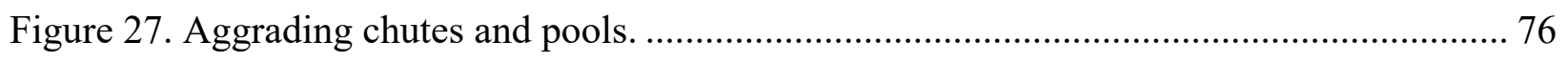

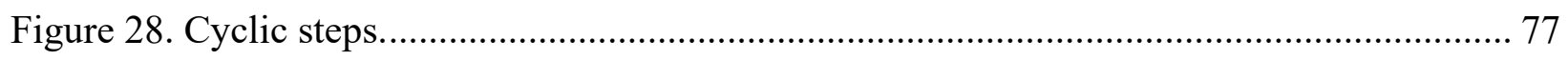

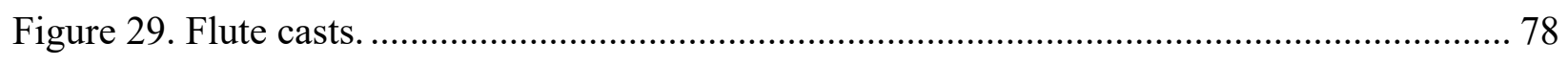

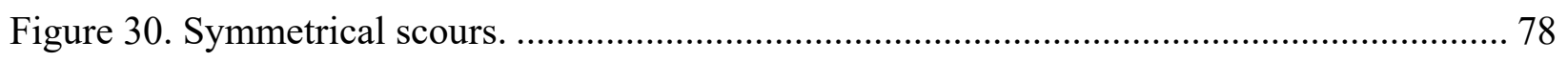

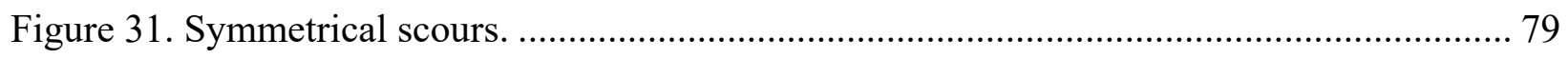

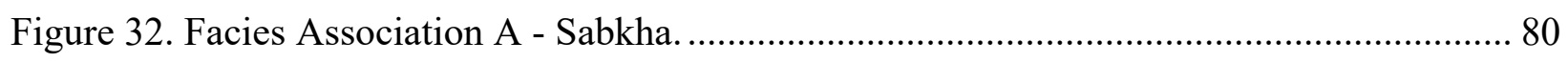

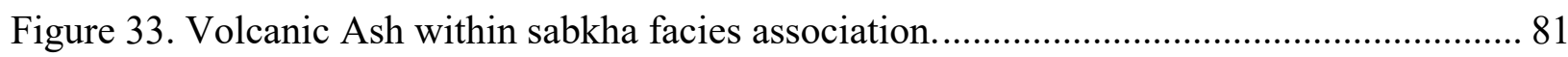

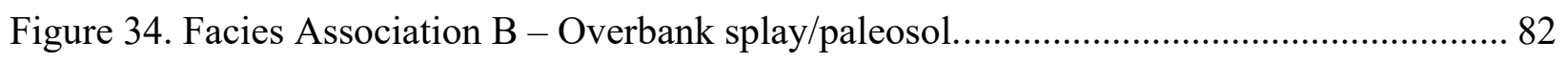

Figure 35. Development of overbank splay and paleosol packages........................................ 83

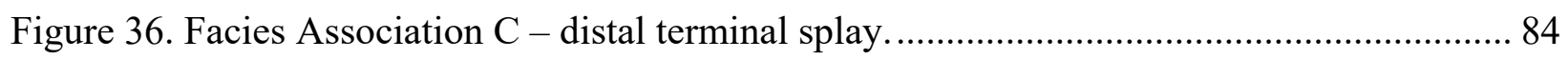

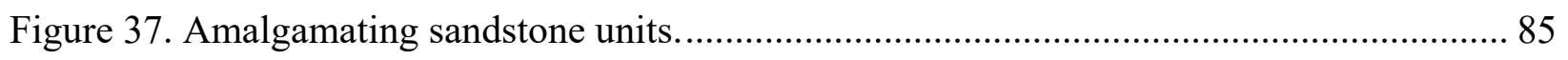

Figure 38. Facies Association D - Hyper-distal terminal splay. ………………………............. 86

Figure 39. Coarsening upward succession of facies associations A and B. ............................... 88

Figure 40. Regional cross-section of the sedimentary system of the upper Entrada Sandstone... 89

Figure 41. Satellite imagery of a terminal splay in Lake Frome, Australia................................... 90

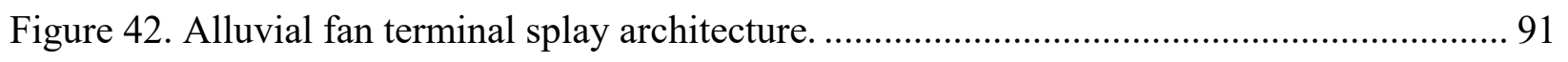

Figure 43. Paleogeographic reconstruction of Utah during the Middle Jurassic Callovian ......... 92

Figure 44. Paleocurrent measurements for the I-70 section. ................................................... 101

Figure 45. Paleocurrent measurements for the Moore Road South section................................ 101 
Figure 46. Paleocurrent measurements for the Moore Road North section............................ 102

Figure 47. Paleocurrent measurements for the Dutch Flat South section............................. 102

Figure 48. Paleocurrent measurements for the Dutch Flat North section............................. 103

Figure 49. Paleocurrent measurements for the Green River Cutoff section........................... 103

Figure 50. Paleocurrent measurements for the Cedar Mesa section..................................... 104 


\section{Facies at the Tephra of Moore Road}

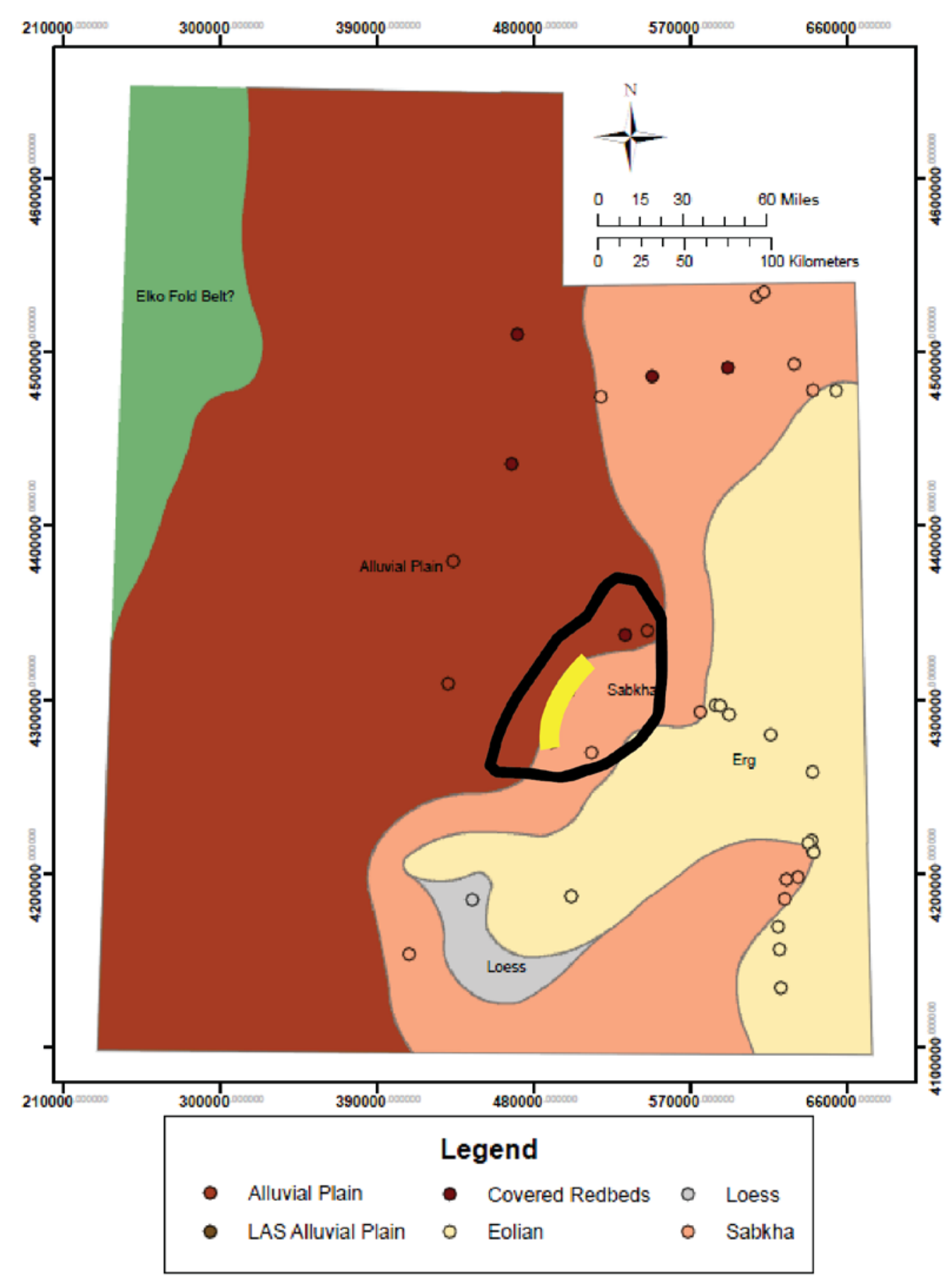

Figure 1. Paleogeography of Utah during Middle Jurassic Callovian time. Facies are correlated to the ash bed, or tephra, of Moore Road. All but one measured section contains this tephra unit, and stratigraphic columns are correlated to it. Jennings (2014) interpreted the redbeds of the upper Entrada to represent alluvial plain and sabkha facies. Outlined in black is the San Rafael Swell, a Laramide uplift that exposes a thick succession of Jurassic strata. The study area is marked in yellow. Modified from Jennings, 2014. 


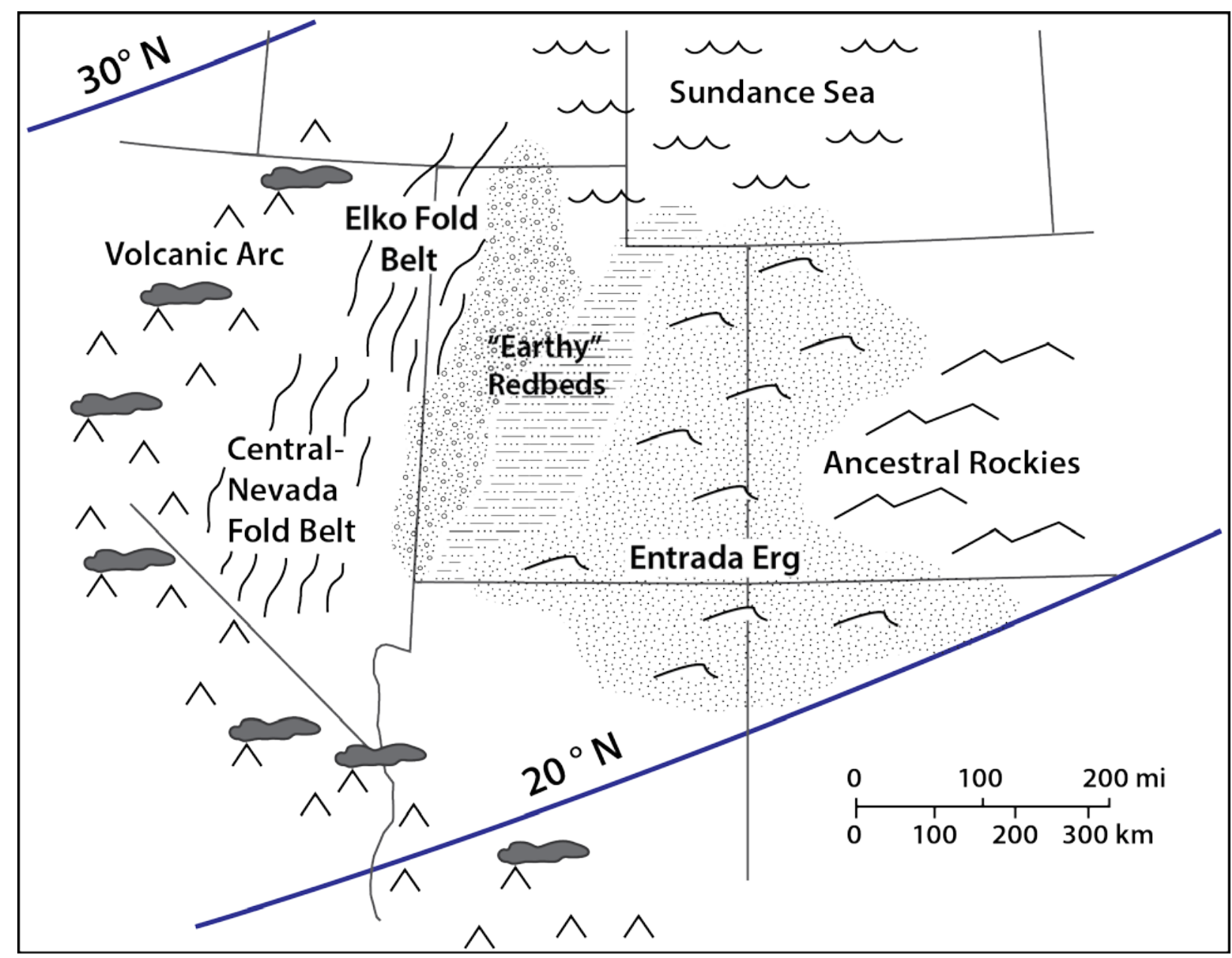

Figure 2. Paleogeography of the central Rockies during Middle Jurassic Callovian time. Subduction at the western continental margin induced arc volcanism and compressed the continental crust, giving rise to the Elko and Central Nevada fold belts. Crustal loading from these orogenic events created a retroarc foreland basin, which accommodated sediments being shed off of the uplifted crust. These sediments, combined with windblown sediments derived from the Entrada erg, comprise the "earthy" redbeds of the western Entrada Sandstone, the focus of this study. Modified from Dossett, 2014. 


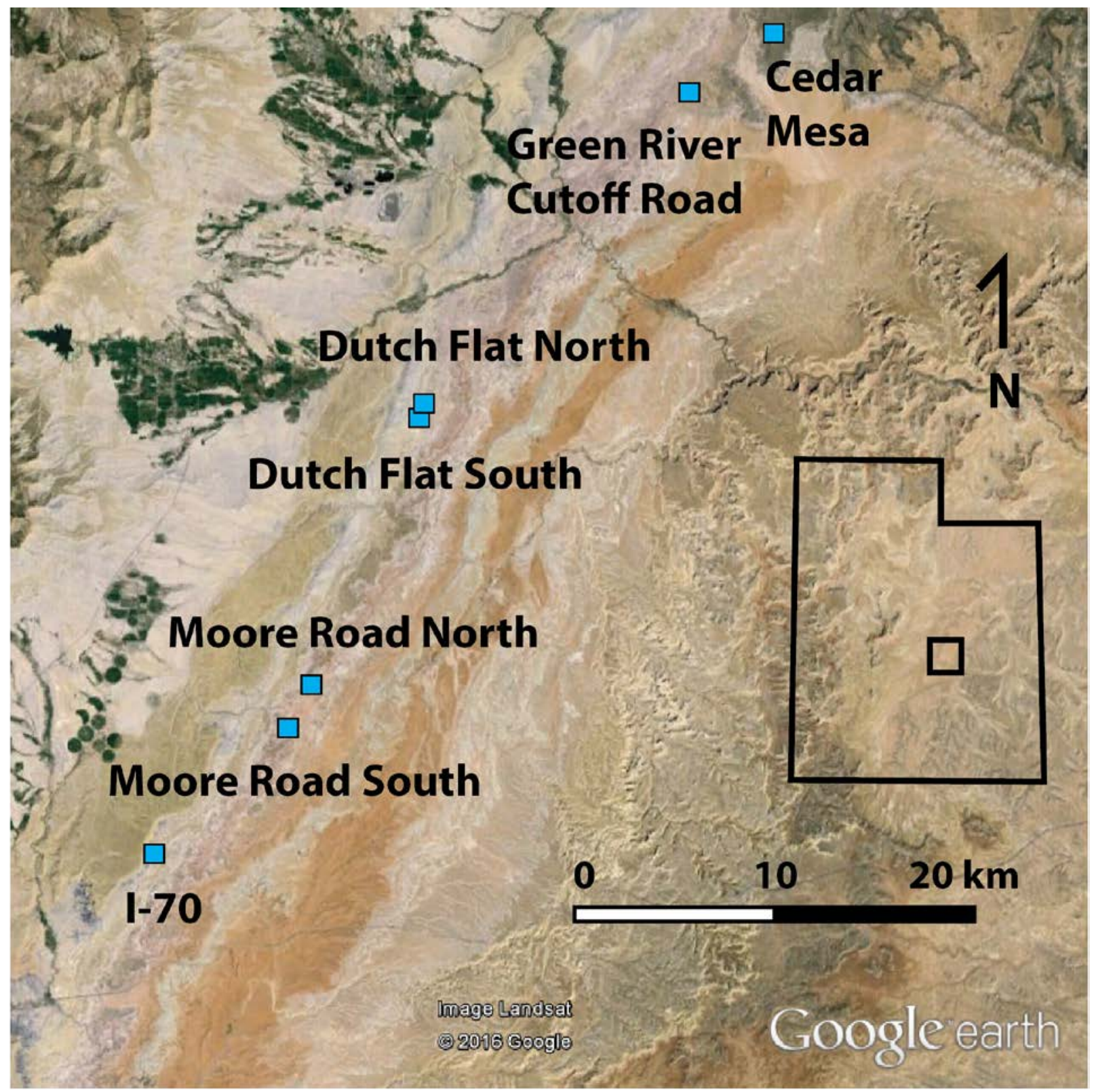

Figure 3. Locations of measured sections along the western flank of the San Rafael Swell. Sections were measured in pairs separated by different distances, in order to observe any short or long distance trends. The section measured at I-70 was used to identify trends or variability from the Moore Road sections. Satellite image courtesy of Google Earth. 


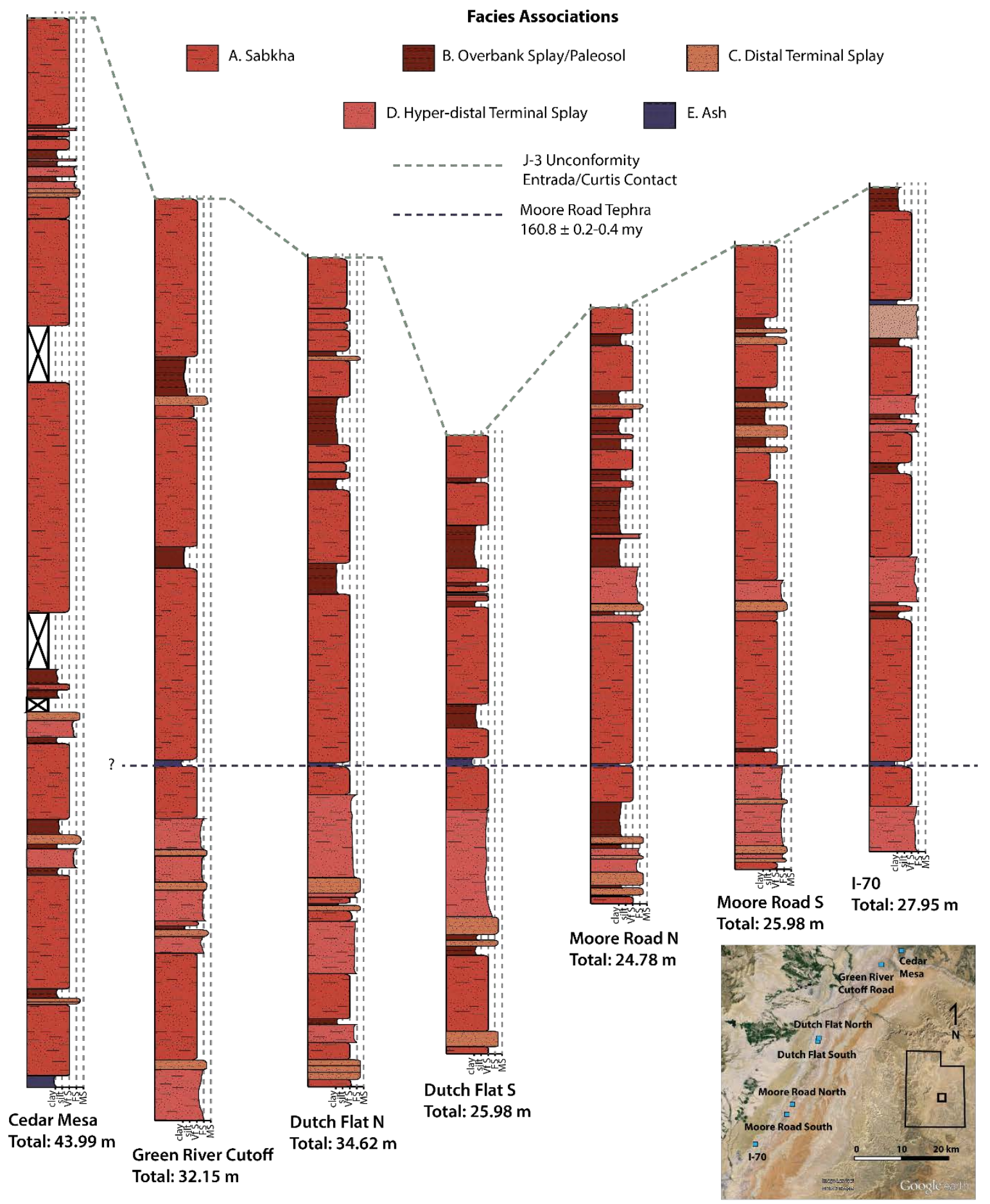

Figure 4. Stratigraphic columns of measured sections. Seven sections were measured along the western San Rafael Swell, Emery County, UT. Columns were hung on the Moore Road Tephra (described and dated by Dossett, 2014) found within a thick sabkha unit within the upper Entrada (with the exception of the Cedar Mesa section, due to lack of certainty of correlation). The upper Entrada was considered to begin at the top of the thick sabkha interval found in the middle Entrada Sandstone and to end at the J-3 Curtis/Entrada contact. The upper Entrada can be divided into three intervals, dominated by different facies associations: 1) terminal splay sandsheets, 2) thick, nearly uninterrupted sabkha, 3) Overbank or terminal channel splays. See Trends section for full discussion. 


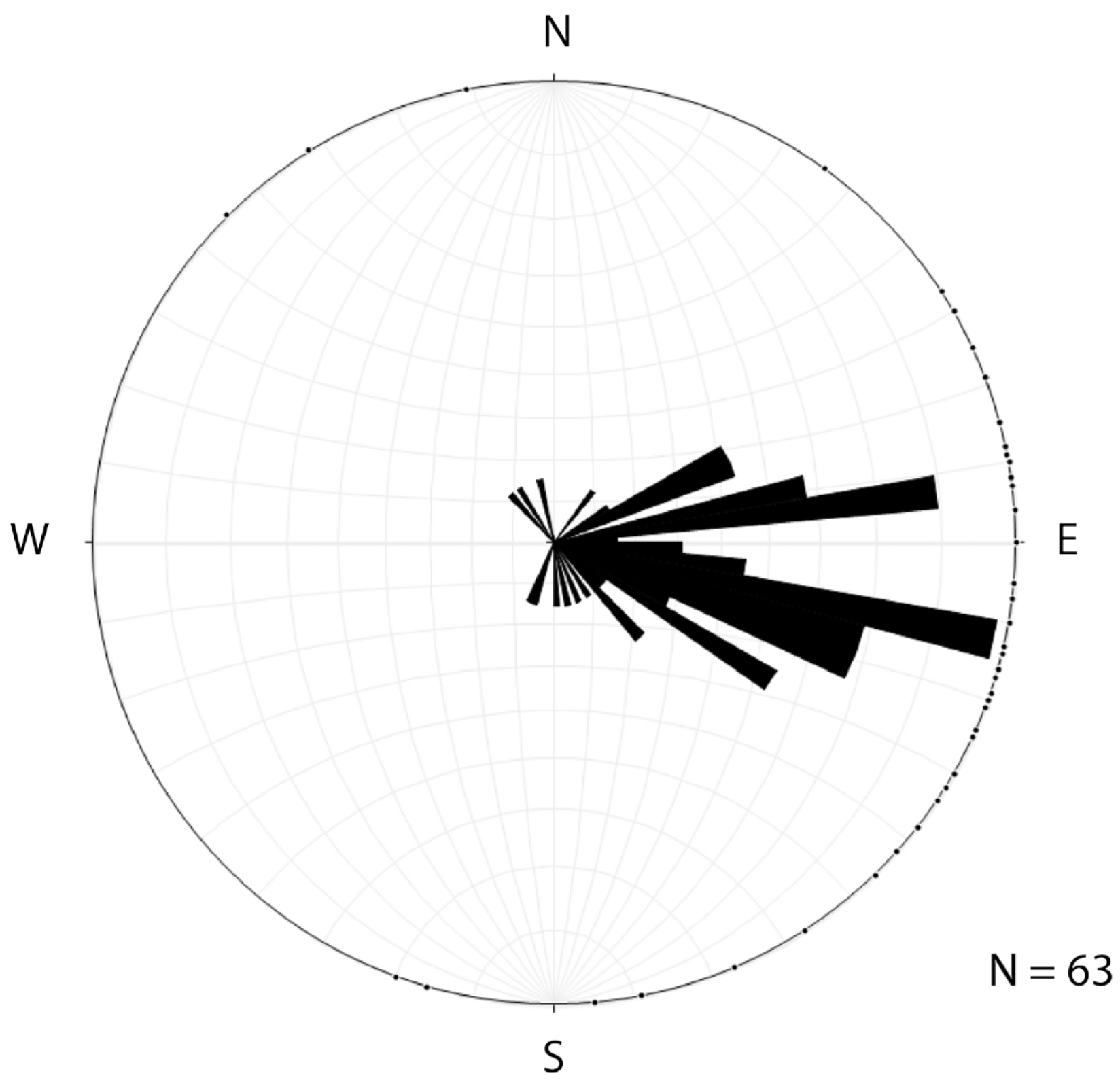

Figure 5. Paleocurrent direction measurements. Note bimodal distribution of direction measurements, with a slight trend towards the south from an otherwise easterly direction. Outlier direction measurements may be the result of strongly meandering fluvial channels, meandering of the flow path within a channel, or some bedforms being falsely identified as subcritical bedforms, when they were actually supercritical ones. This would skew directions by 180 degrees, as foresets of supercritical bedforms dip upstream as opposed to downstream, as subcritical bedforms do. Rose diagrams were created using the Stereonet program. 


\section{Facies at the Tephra of Moore Road}

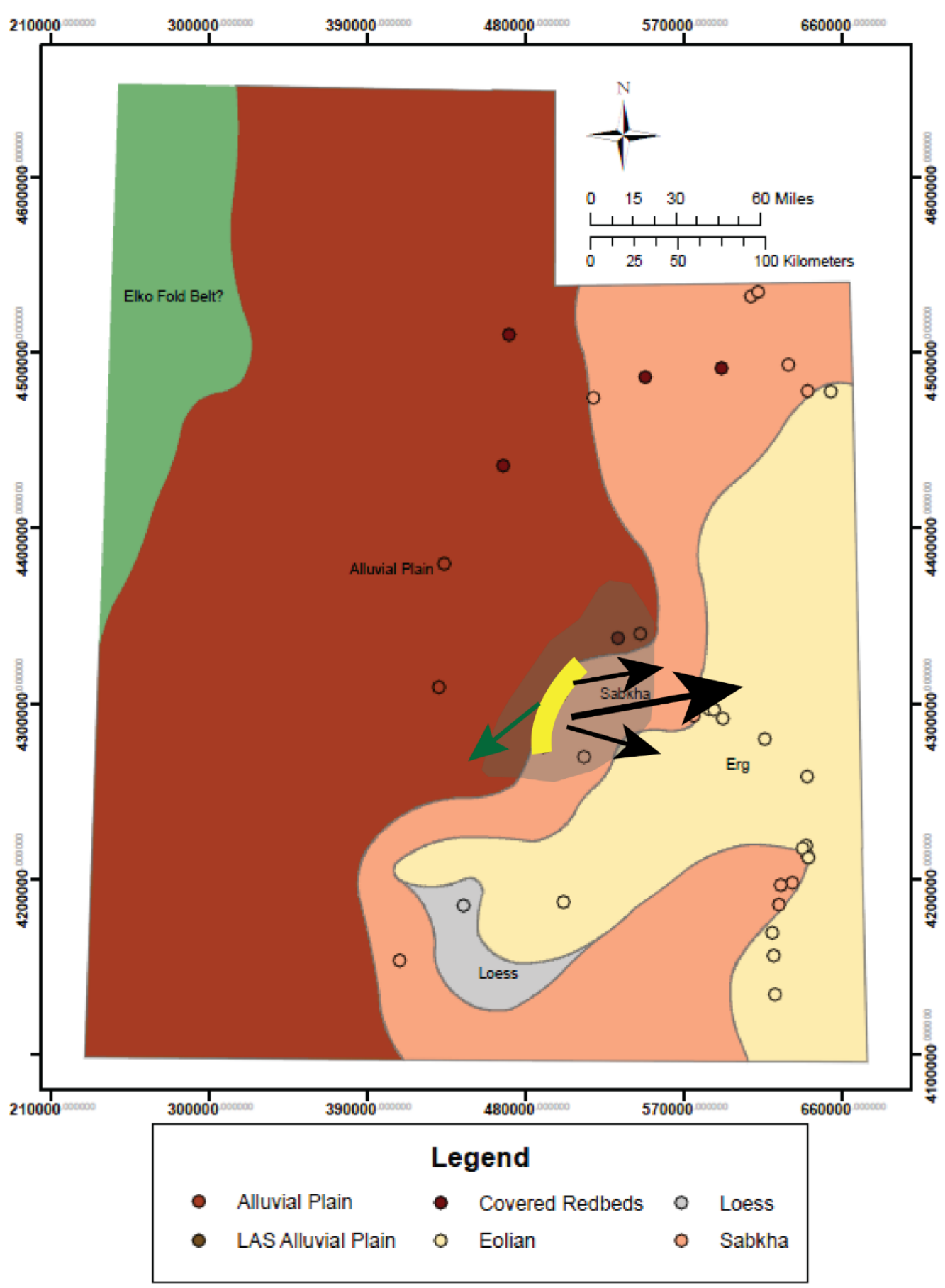

Figure 6. Paleocurrent direction mean average vectors. Vectors for interpreted aqueous bedforms are shown with black arrows. The eolian vector is shown with a green arrow. The two smaller arrows indicate the bimodal distribution of aqueous paleocurrent directions, and the larger black arrow is the mean average vector for all aqueous paleocurrent directions. Eolian measurements were rare, so the mean average vector for these may represent a localized trend, and may not be applicable on a regional scale. Modified from Jennings, 2014. 


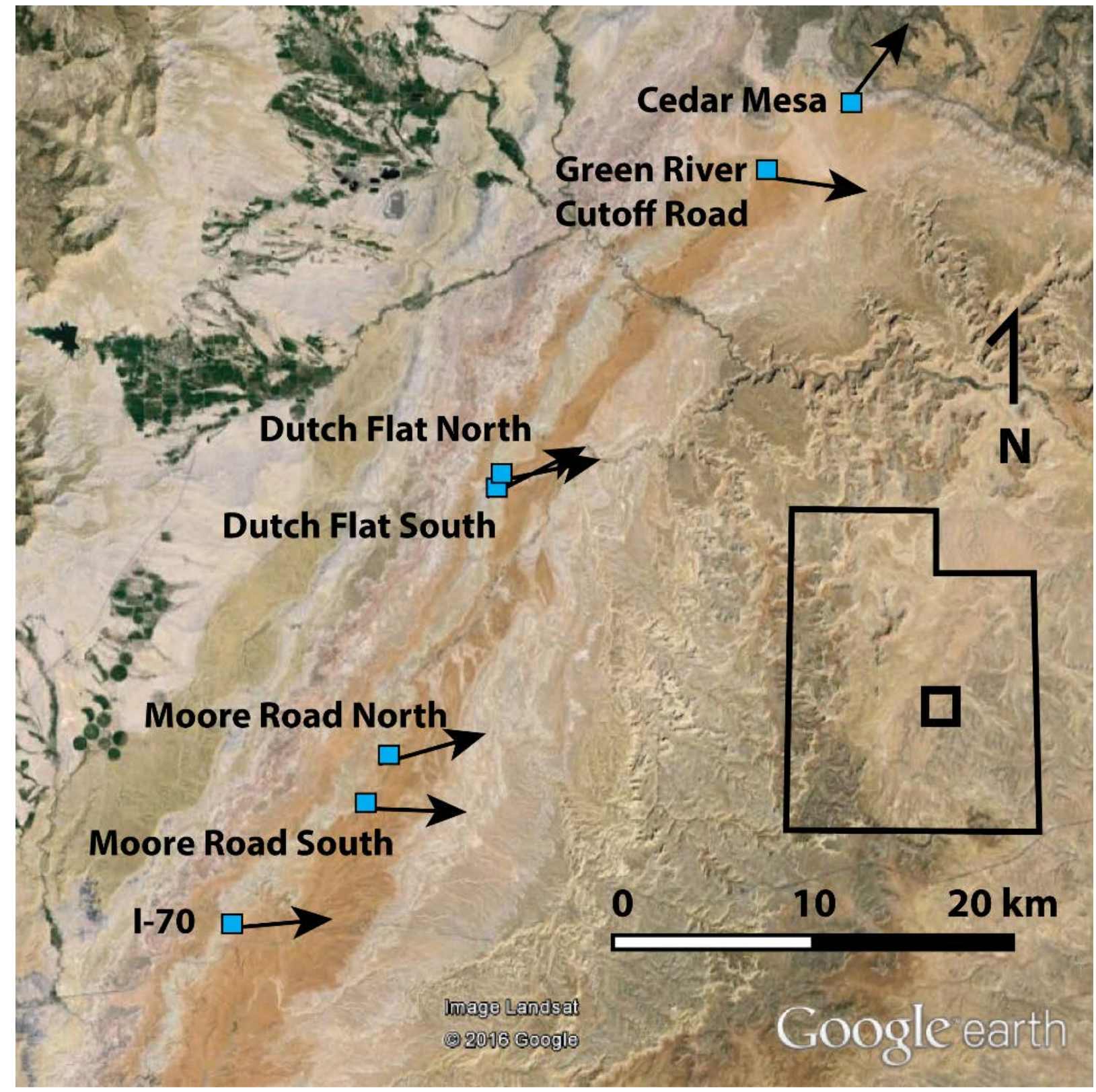

Figure 7. Paleocurrent direction mean average vectors for each measured section. The paleocurrent directions measured at Cedar Mesa depart from the stronger easterly trend exhibited by paleocurrents directions measured at the other measured sections. Satellite image courtesy of Google Earth. 


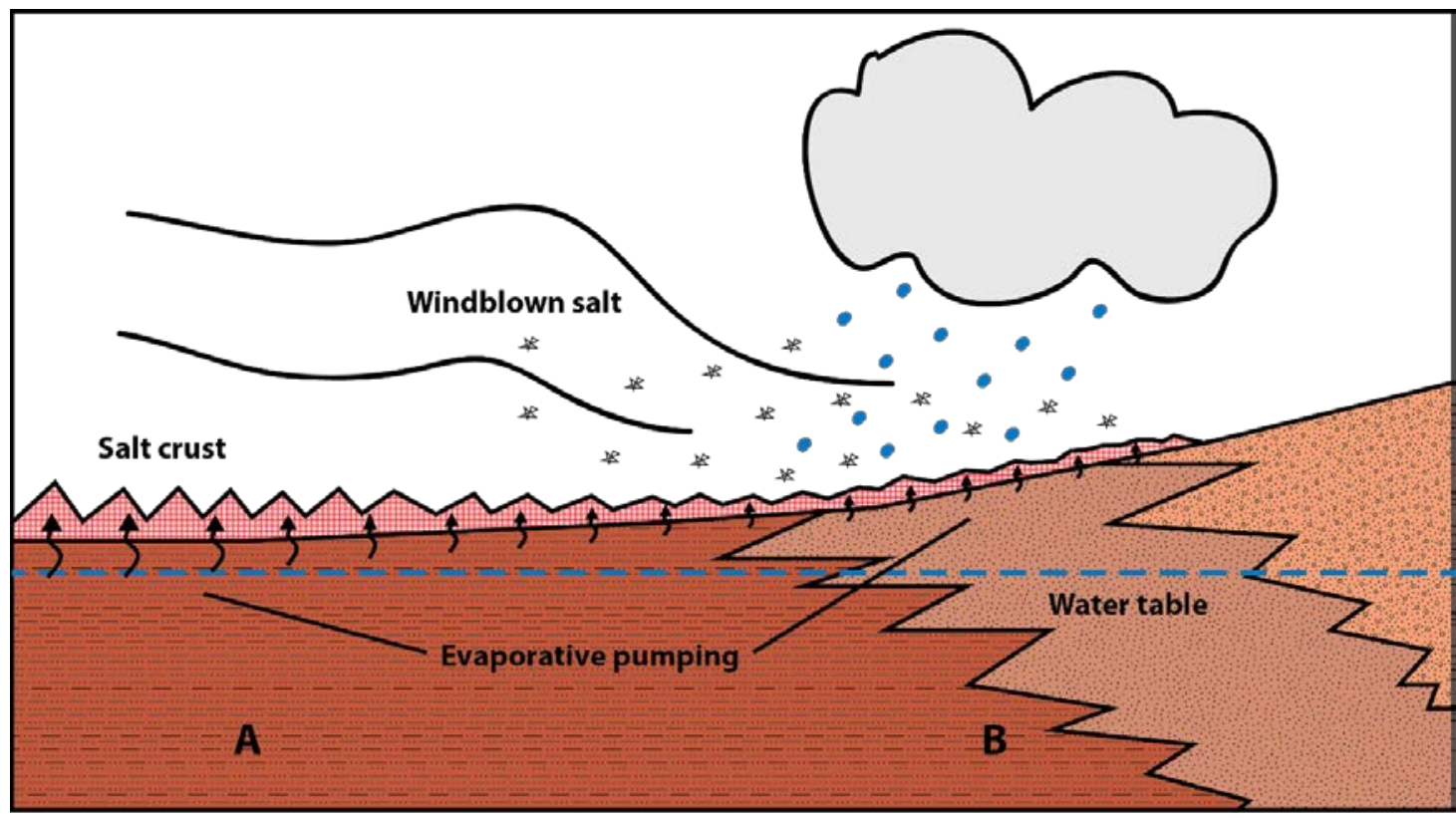

Salt crust

Sabkha sediments

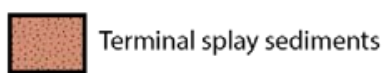

Alluvial fan sediments

Figure 8. Environments of salt crust efflorescence. Thickness of salt crust is strongly dependent on the depth of the water table. Where the water table (marked by the blue dashed line) is closer to the surface, higher rates of evaporative pumping occur, and create a thicker crust (location A). Eventually, the water table is too deep to exert an influence on the sediment surface, but eroded and windblown salt particles can accumulate on distal surfaces. During and after precipitation events, salt can dissolve and recrystalize as a thin crust (location B). Modified from Smoot and Castens-Seidell (1994).

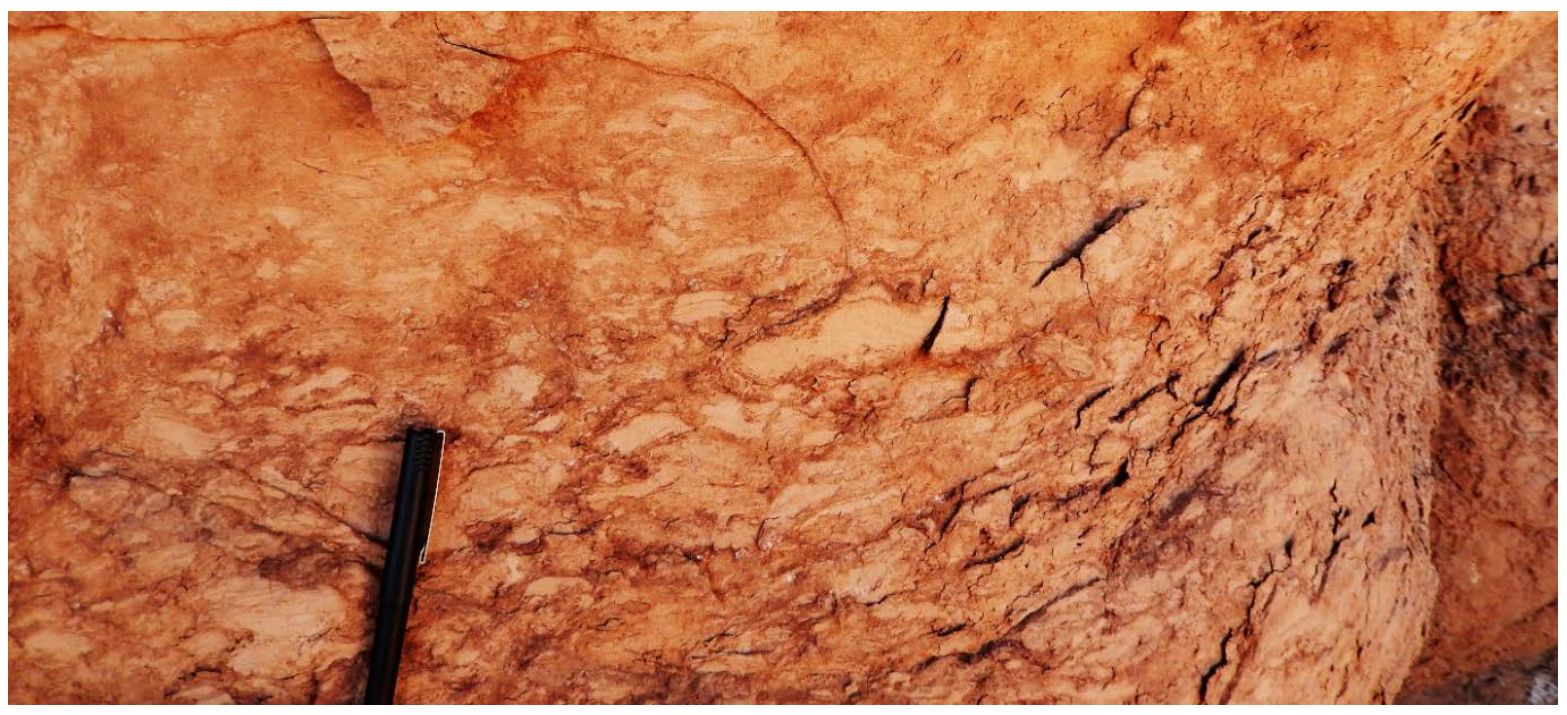

Figure 9. Wispy lamination and irregular sand lenses or "sand-patch" fabric. These textures are the most common in the study interval, and are hosted by the majority of sabkha facies units. Pen for scale. 


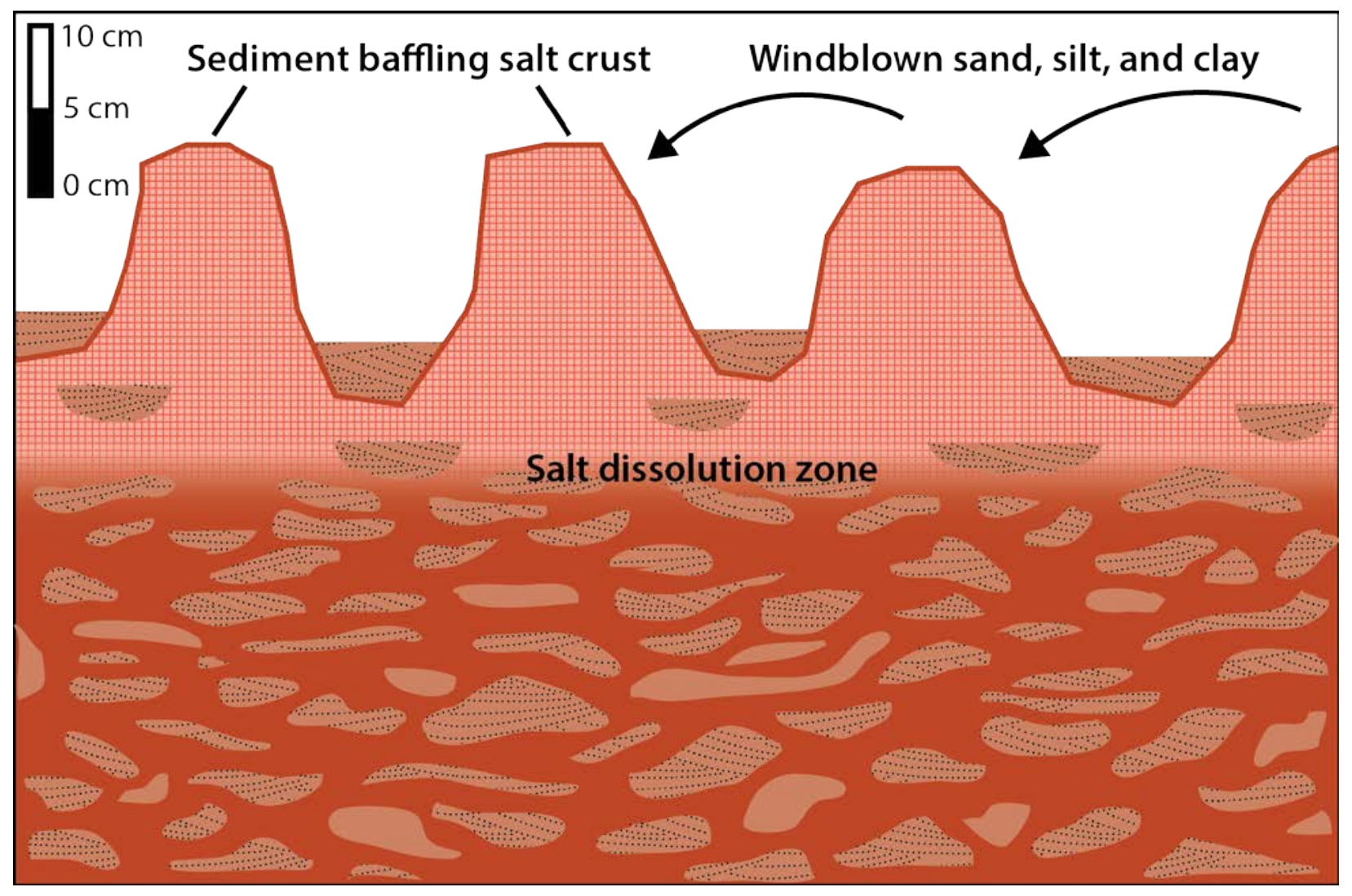

Figure 10. Salt crust entrapment of windblown sediments. Development of salt crust provides accommodation for windblown sediments, with coarser grains being deposited in lows, and finer grains adhering to hygroscopic salt surfaces. Over time, the salt crust grows over trapped sediments, and with burial, the salt is dissolved when it passes through the water table. This leaves a lag of irregular sand lenses (sand-patch fabric) and mud and silt grains as irregular, faint and wavy laminations (wispy lamination). The latter are apparent when sand-patch fabric is poorly exposed, and mud and silt grain "matrix" makes up a small percentage of the rock. Modified from Smoot and Castens-Seidell (1994). 

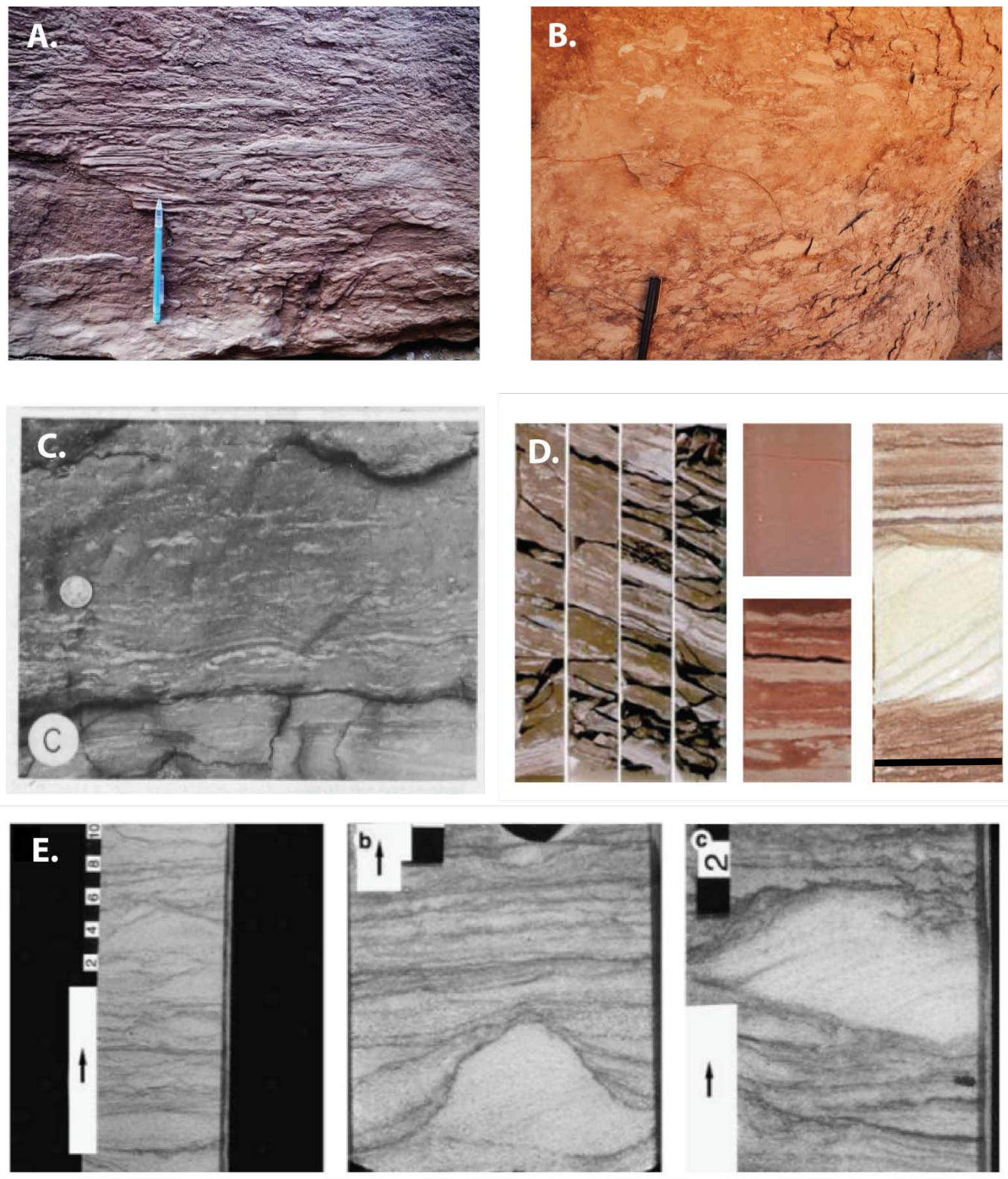

Figure 11. Assorted salt crust textures from various formations. A. Weathered sand-patch fabric exposing high concentration of sand lenses (Moore Road South). B. Sand-patch fabric exhibiting some wispy lamination throughout, where fine grained sediments surround sand lenses (Moore Road South). C. Outcrop photo of mud-flat facies from the Blomidon Formation, Eastern Canada (from Hubert and Hyde, 1982). D. Core photos exhibiting sand-patch fabric from the Skagerrak Formation, North Sea (from McKie, 2014) (10 cm wide core). E. Core photos exhibiting sand-patch fabric from the Ormskirk Formation, North Sea (from Goodall et al., 2000). Similarities in morphology, scale, and texture among all examples suggest processes and depositional environments were also similar. 


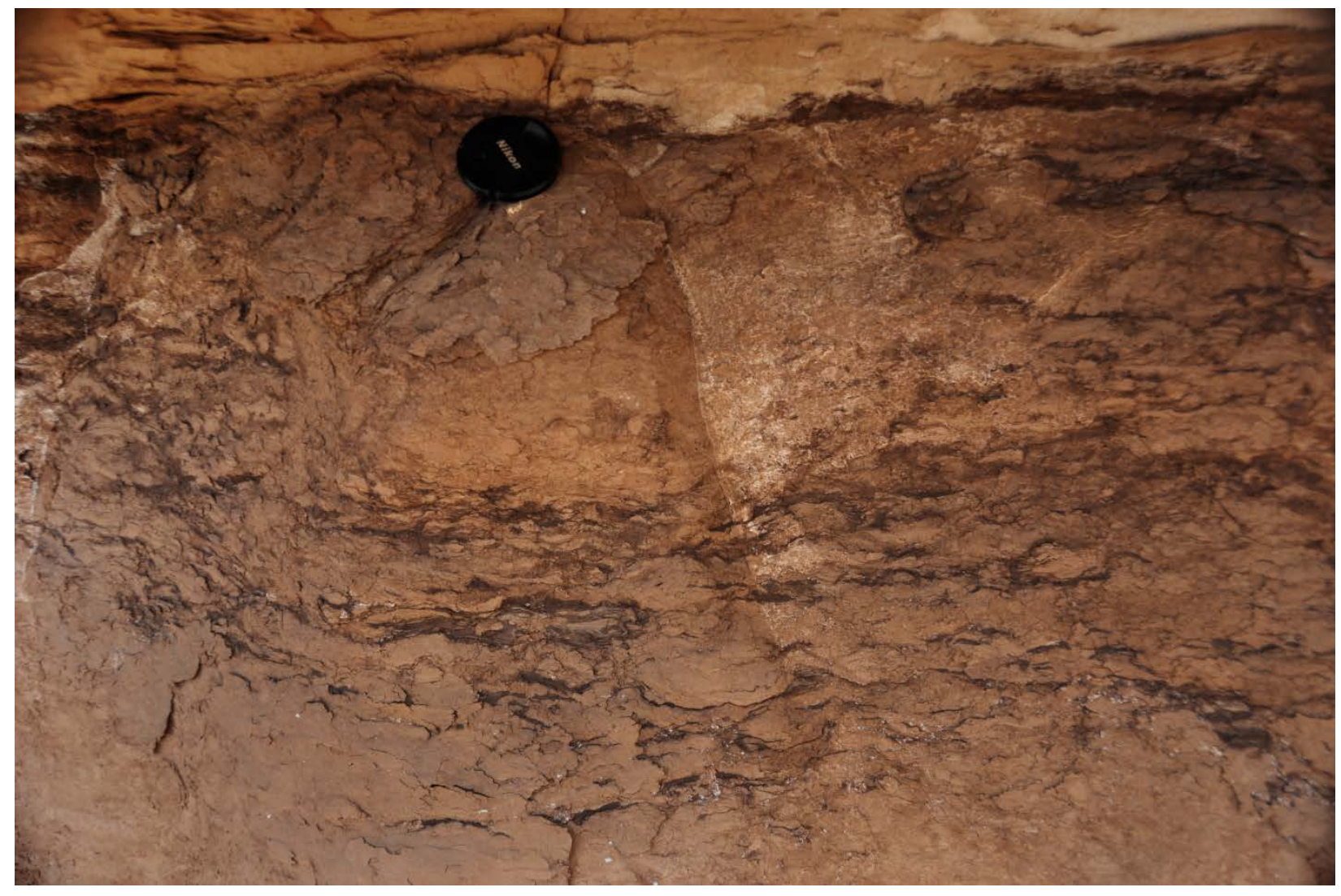

Figure 12. Solution collapse of haloturbated sediments. This process is thought to occur as sediment is trapped and loads underlying salt. Salt dissolves preferentially under higher pressure, creating contorted fabric. Camera lens cap for scale $(5 \mathrm{~cm})$. Note fine grained portion of rock exhibits classic wispy lamination, between sand lenses in sandpatch fabric. 


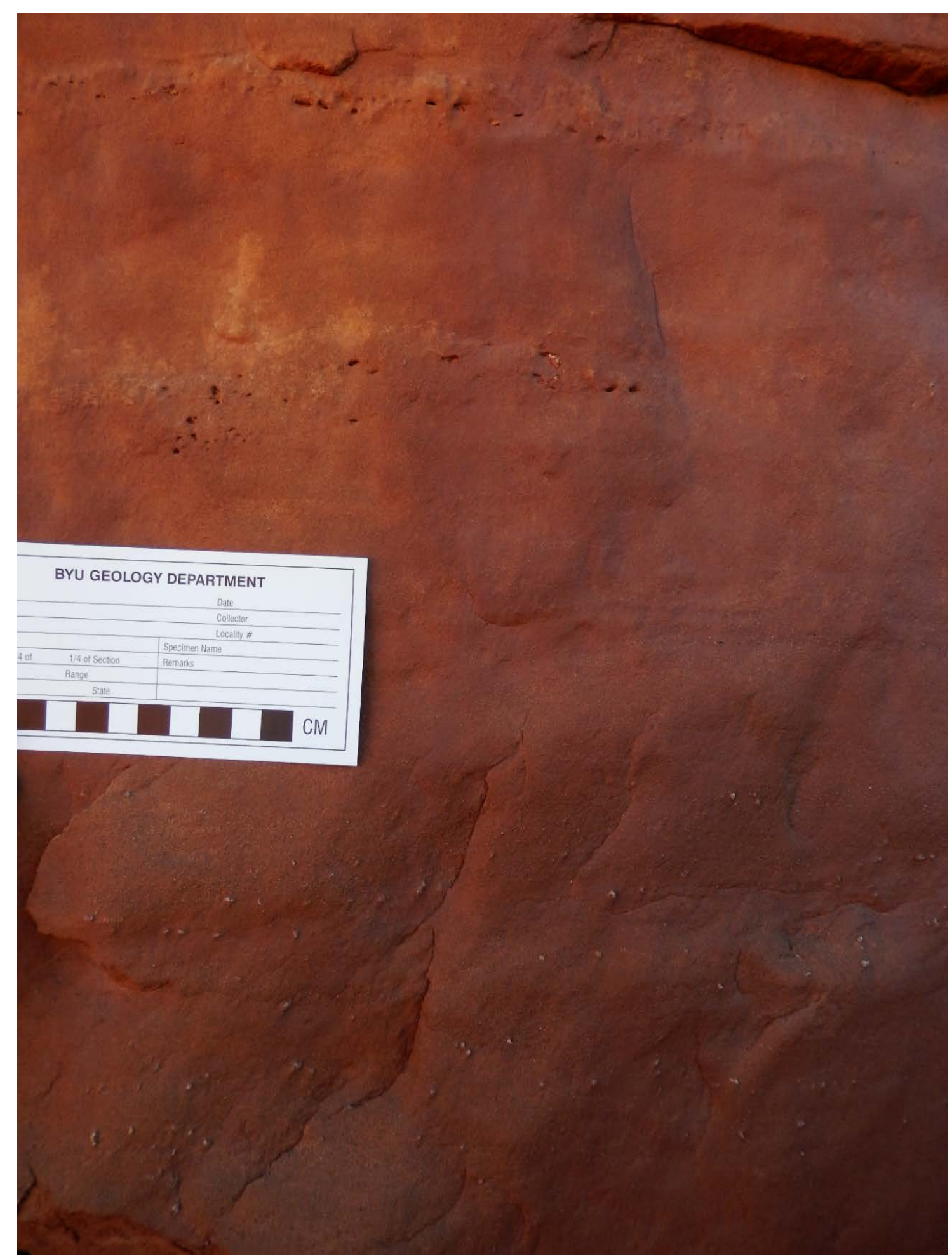

Figure 13. Example of replaced salt nodules. Coarse sand-sized nodules, replaced by quartz or jasper, can form diffuse bands in otherwise massive sandstone. A stable water table with consistent, high evaporation rates may experience significant precipitation of salt crystals in pore spaces, resulting in salt nodules. This process may also destroy primary sedimentary structures (photo taken in the San Rafael Swell, between Moore Road North and Dutch Flat South). 


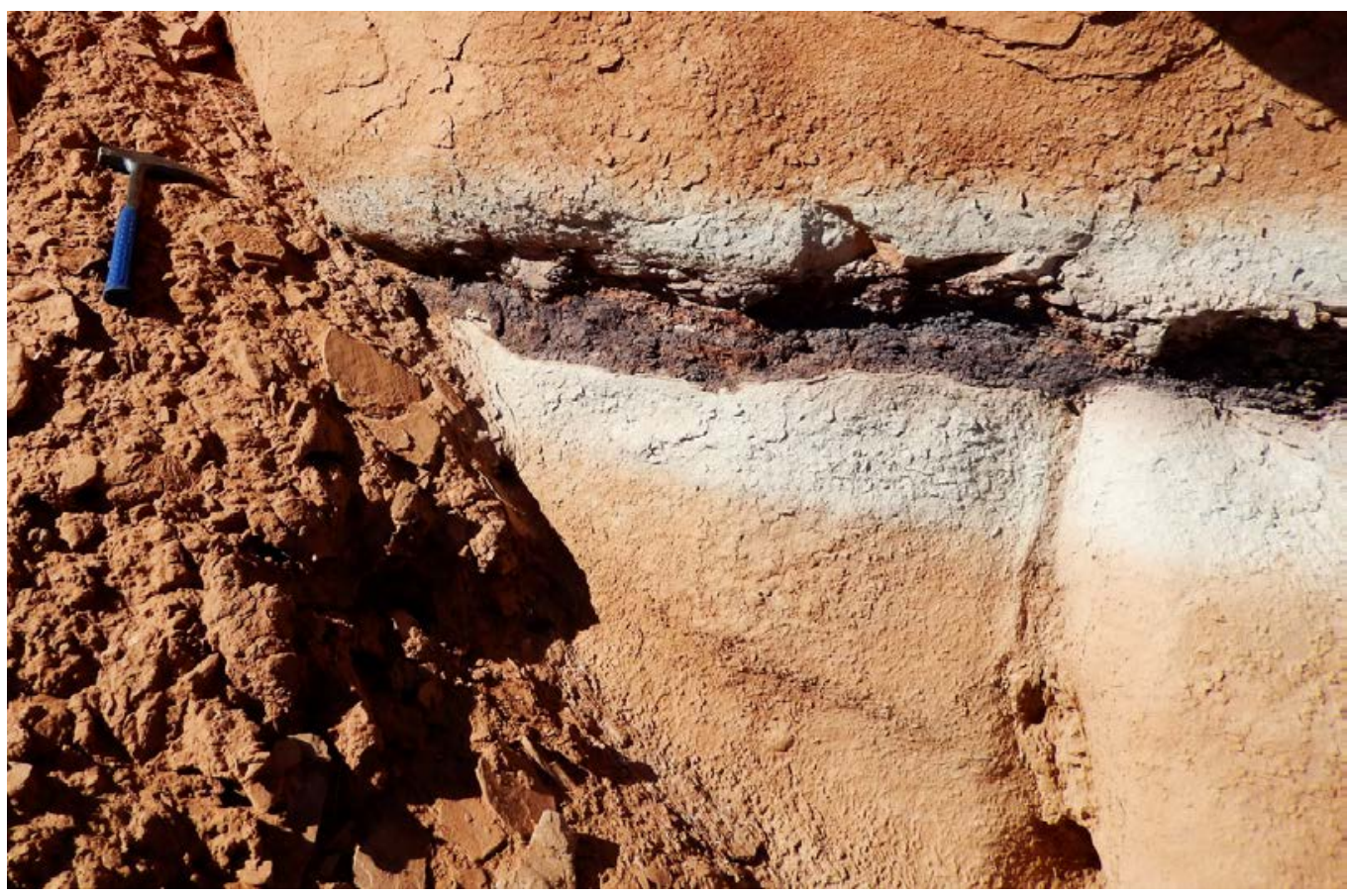

Figure 14. Moore Road Tephra, ash bed. Note bleaching of sandstone above and below dark purple bentonite bed. Preservation of ash indicates that sabkha depositional conditions lacked effective erosional processes.

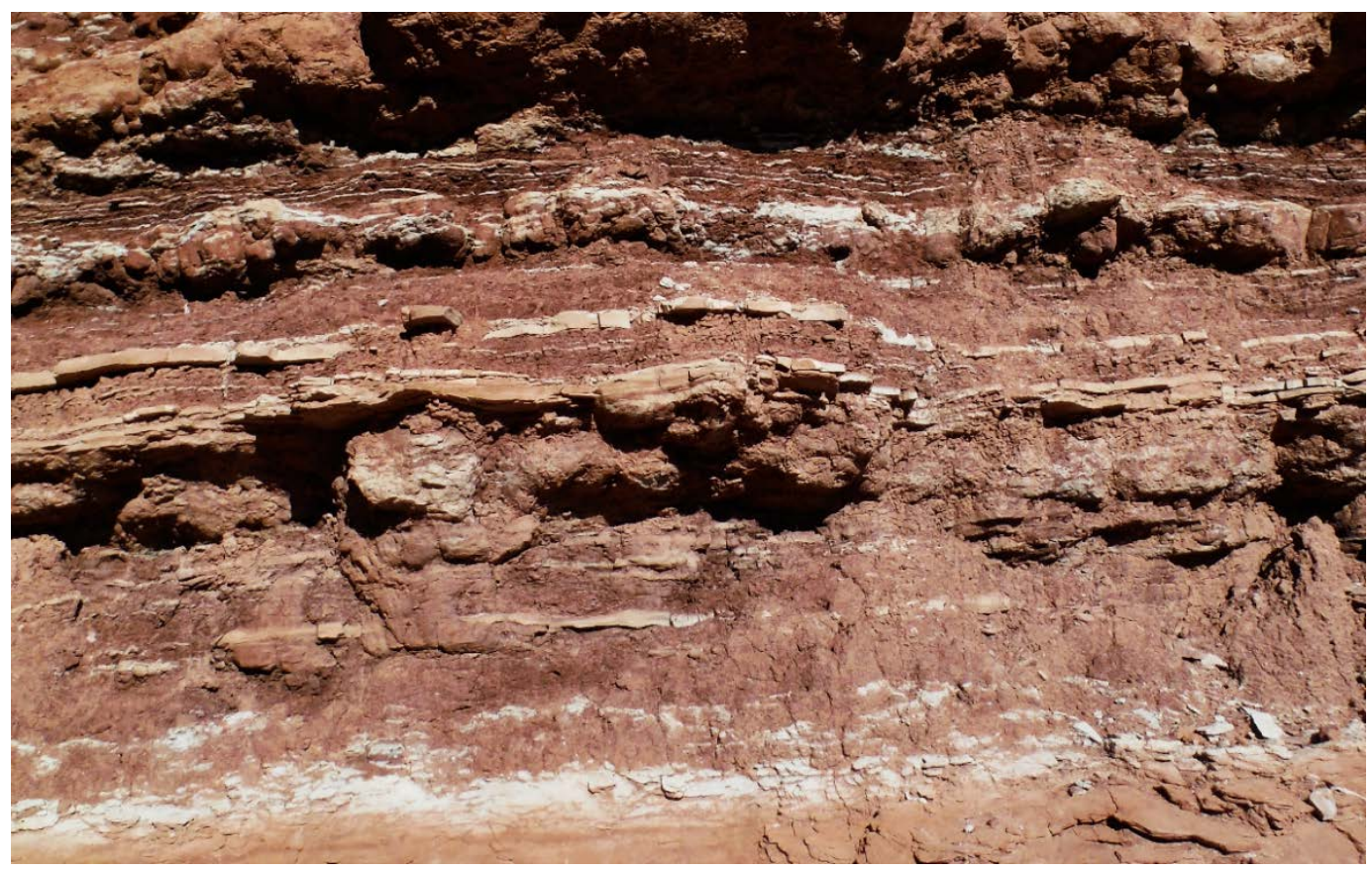

Figure 15. Clay-rich mudstone facies. Dark, clay-rich mudstones are commonly interbedded with irregular, poorlydefined, and bleached sand lenses, as well as better defined, laterally extensive sandstone beds. These latter beds are typically $2-5 \mathrm{~cm}$ in thickness, and may or may not be bleached. Coarser beds within the mudstone units likely represent periods of transitional sabkha development, discussed further in figure 38 . 


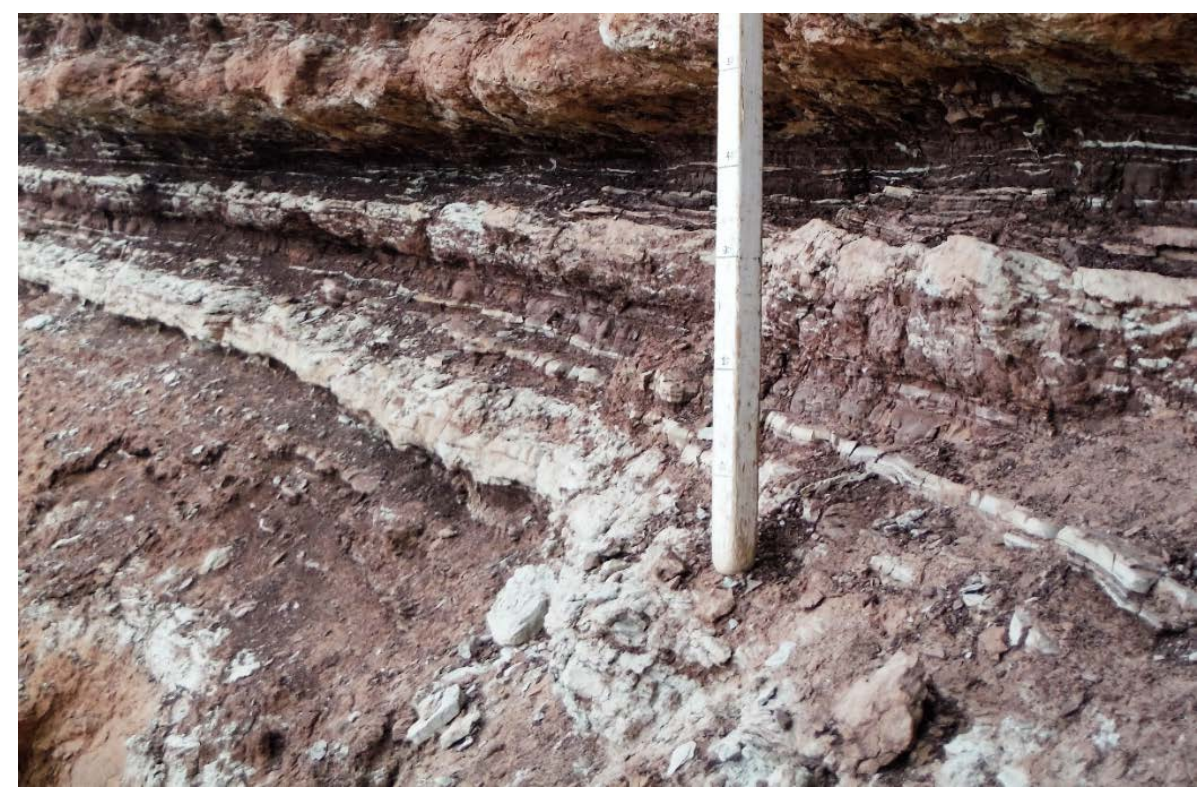

Figure 16. Thin sandstone lenses and continuous sandstone units. These typically accompany clay-rich mudstone beds. Bleaching may be the result of organic material incorporated into mudstones at time of deposition, which subsequently oxidized during decomposition, bleaching nearby sand-rich units. Irregular pattern of bleached sand may be a result of processes present in paleosol development, including desiccation cracks and bioturbation.

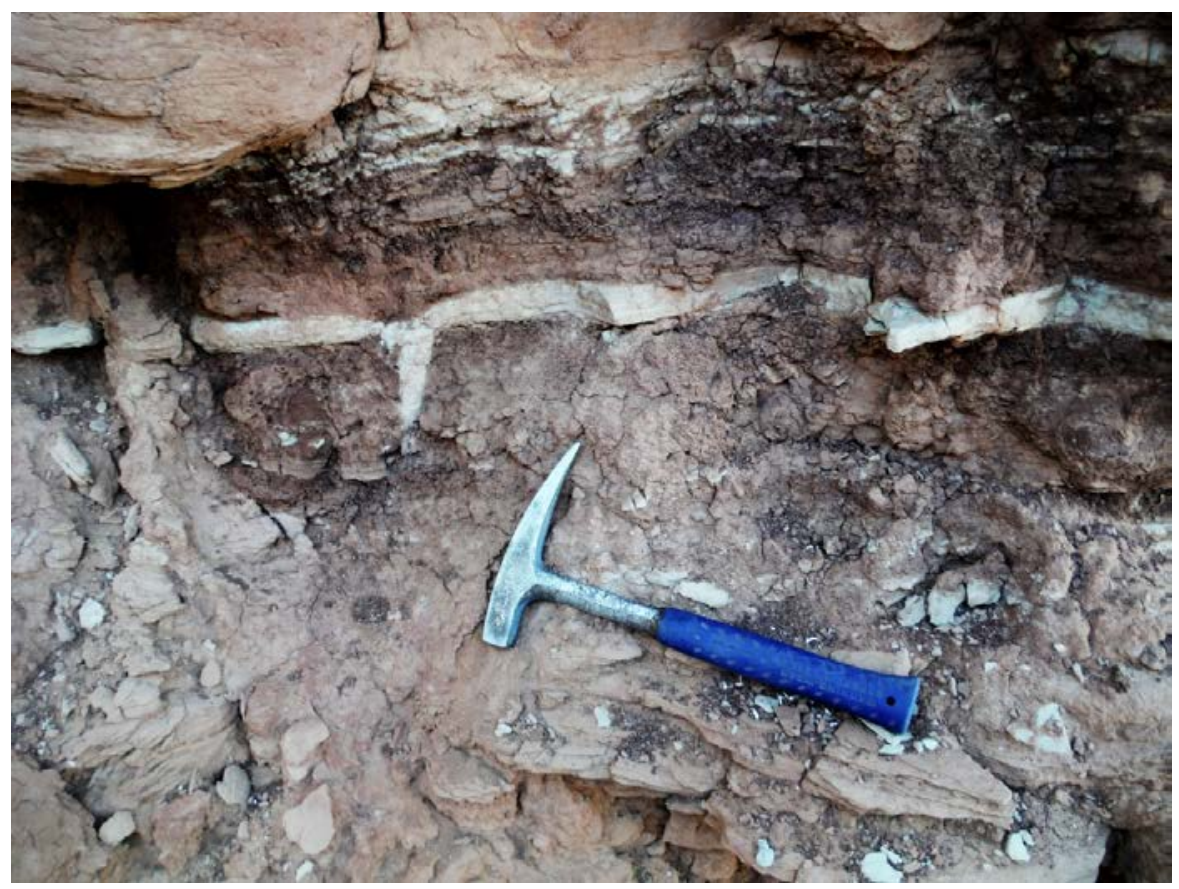

Figure 17. Mud crack dagger. Classic example of a clay-rich paleosurface which experienced desiccation and shrinkage, creating accommodation for subsequent sedimentation events. Here, a bleached sandstone unit has filled a mudcrack in dark red mudstone, providing stark contrast. 


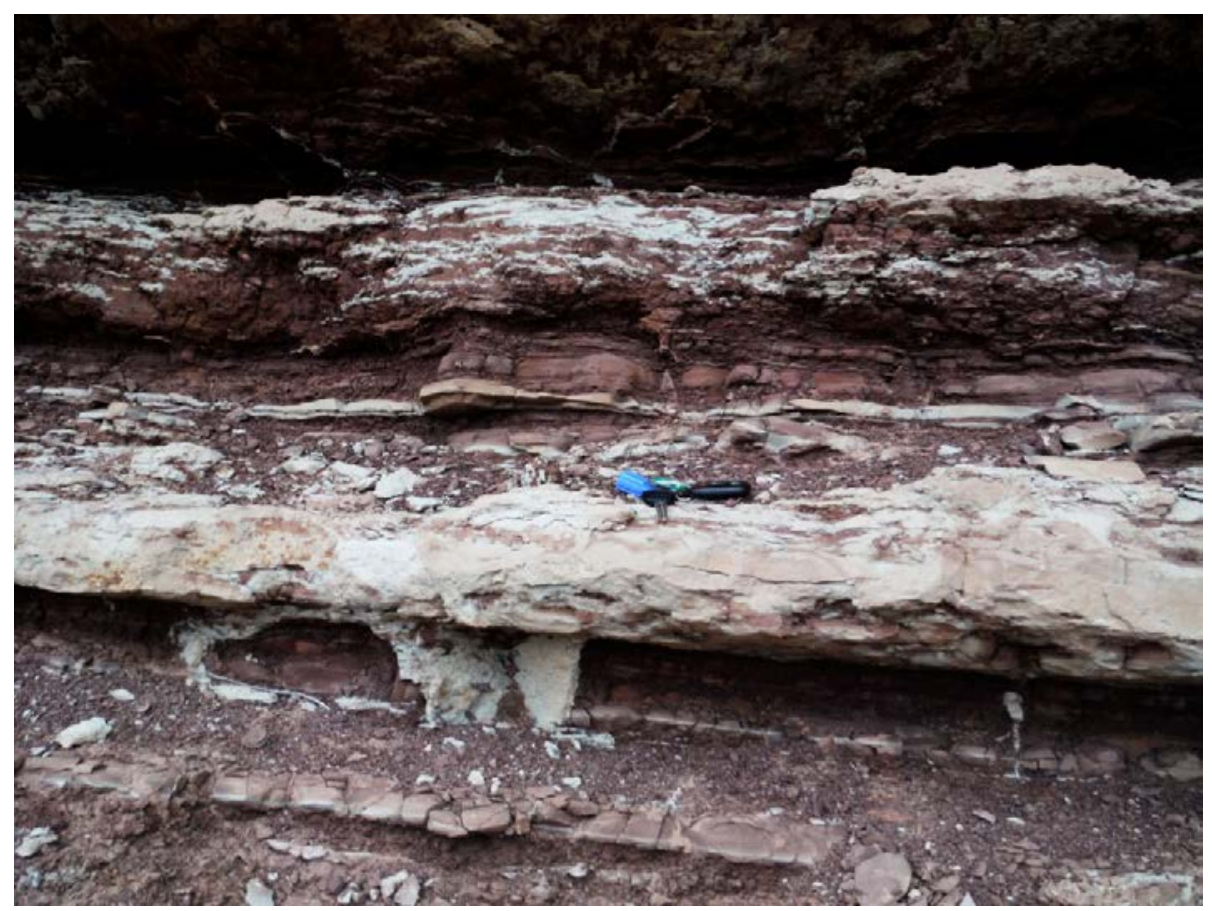

Figure 18. Mud crack walls. Here, multiple dimensions of a mud crack polygon were filled, and weathering has exposed the intersection of multiple walls. A typical dagger is present in the same unit to the right side of the same mudstone unit. Keys for scale.

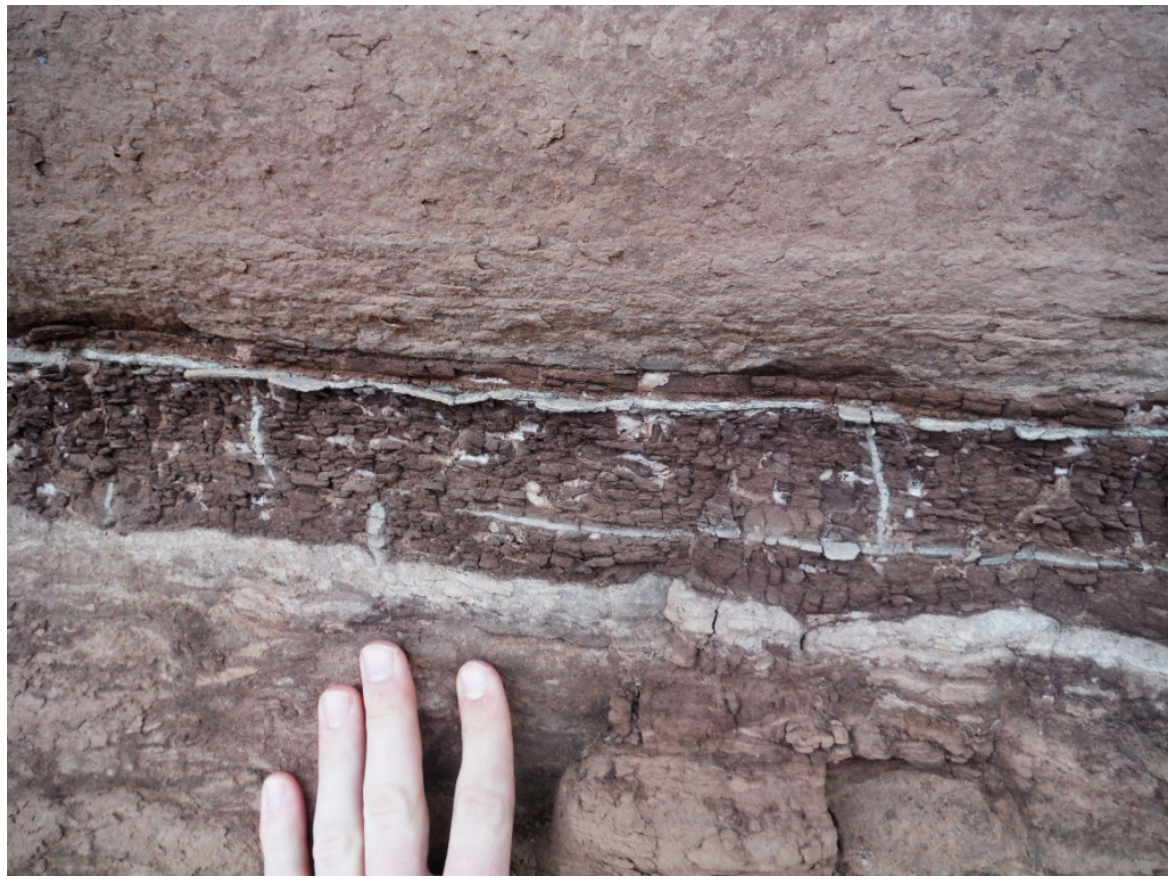

Figure 19. Root traces. Clay-rich mudstone unit exhibiting extensive and well-preserved root traces. Decomposing organic material left over from root material would be an effective bleaching agent for sediment fill. 


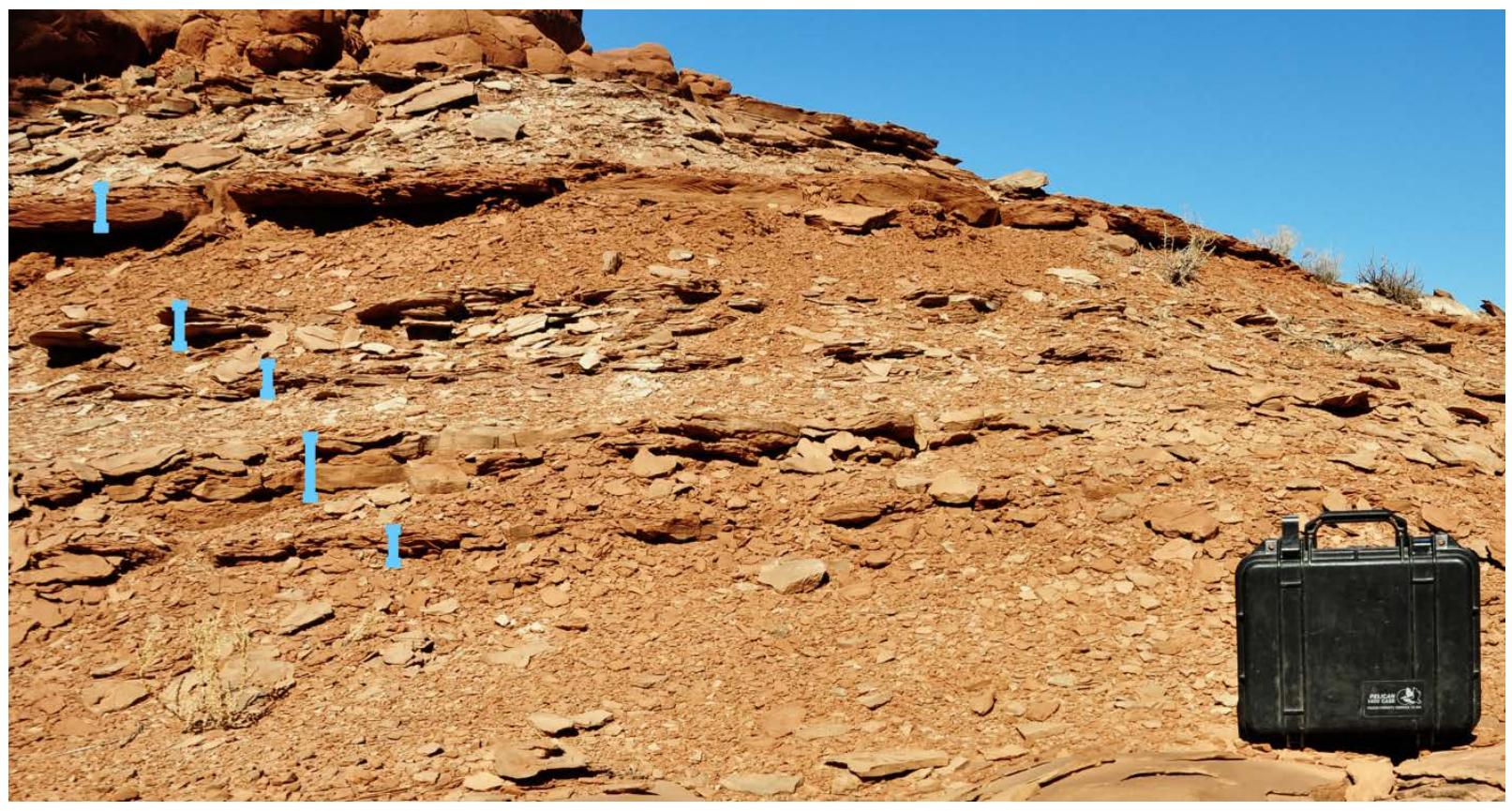

Figure 20. Ripple bundles. Thin sandstone units with poorly preserved ripples were found in single or multiple units. Bundles are marked by blue brackets. Units exhibited pinching and swelling over short distances, and were almost always hosted by thick, slope-forming siltstone units. Camera case for scale $(\sim 0.5 \mathrm{~m}$ wide) .

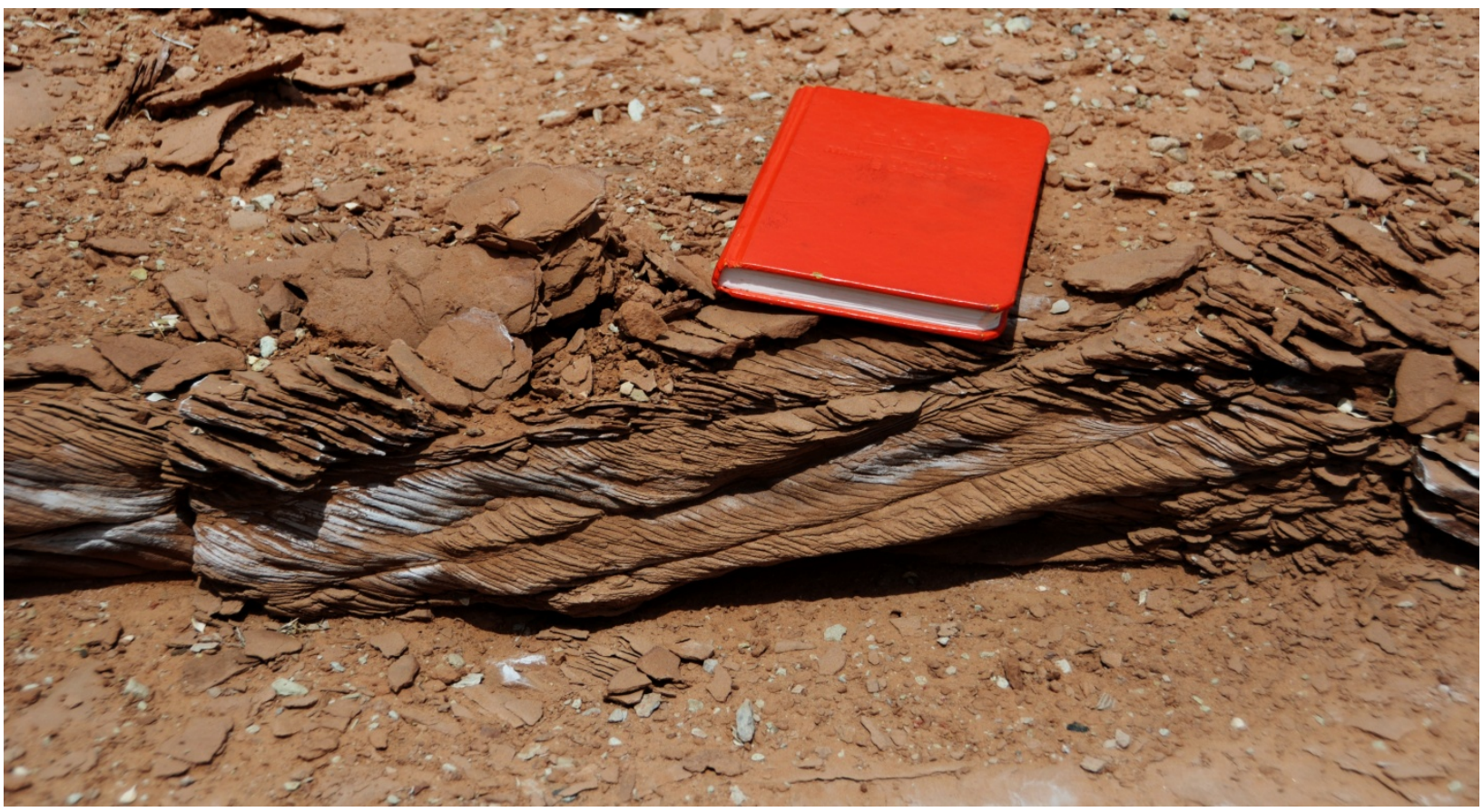

Figure 21. Climbing ripples. Note that only the lee side of the ripples are preserved. The stoss sides of ripples were reworked where bedform migration rates exceeded sediment aggradation rates. 


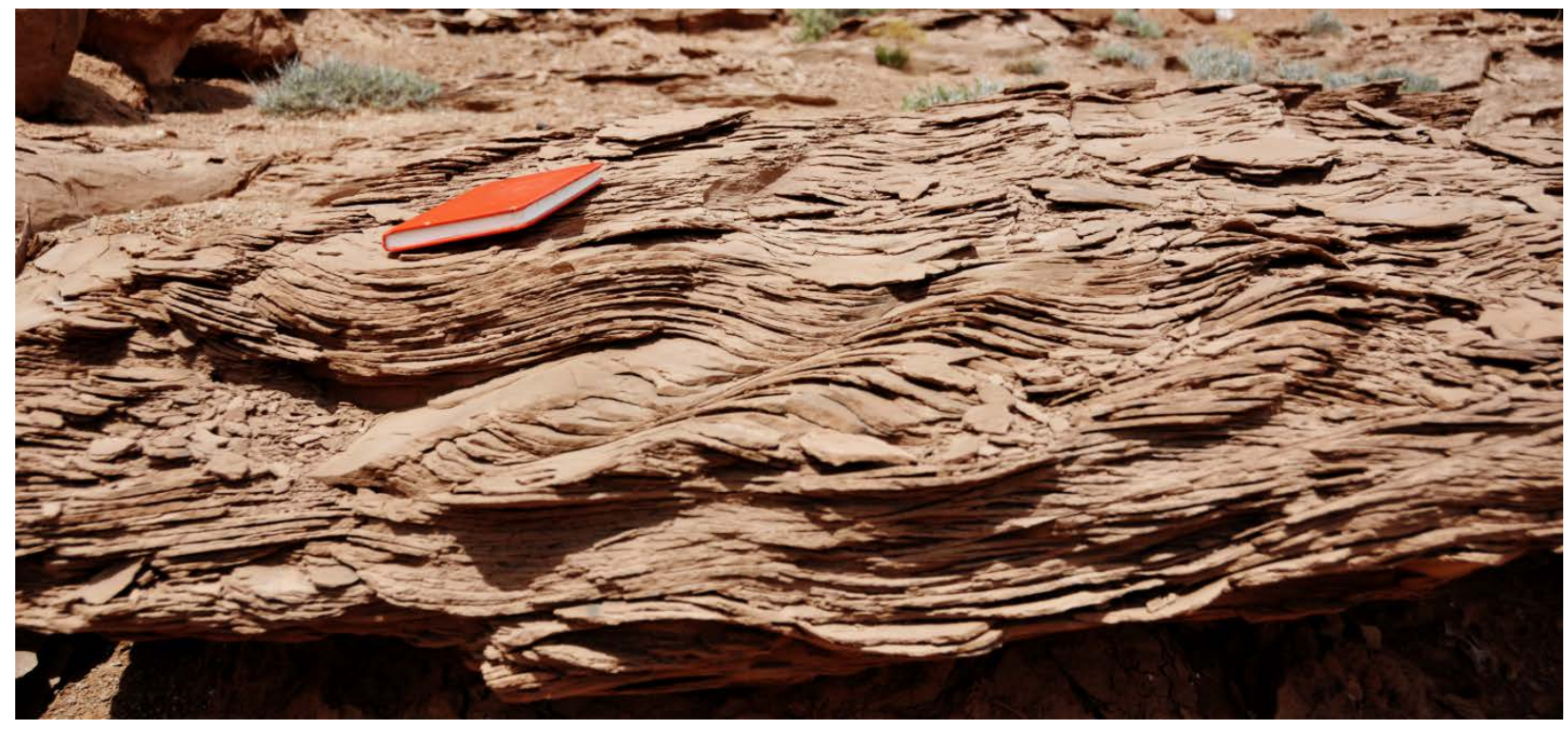

Figure 22. Large climbing ripples. This facies represents a flow event with a high sedimentation rate, likely due to a high sediment load and a decrease in flow velocity. Note that both lee and stoss sides are preserved, indicating that the sediment aggradation rate exceeded bedform migration rate.

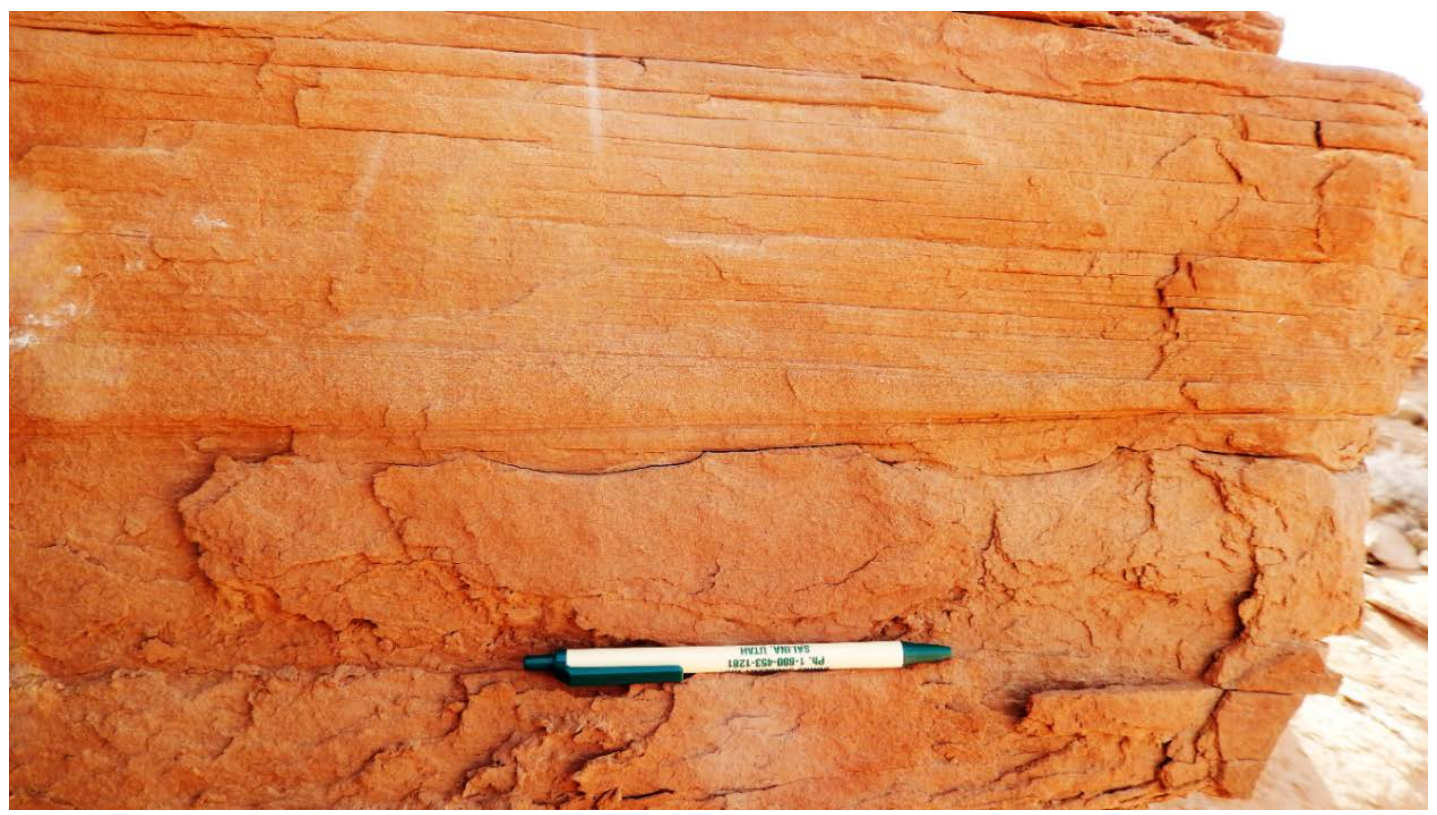

Figure 23. Planar Lamination. Bottom half of photo shows a massive sandstone unit, scoured by an overlying sandstone unit exhibiting planar lamination. 


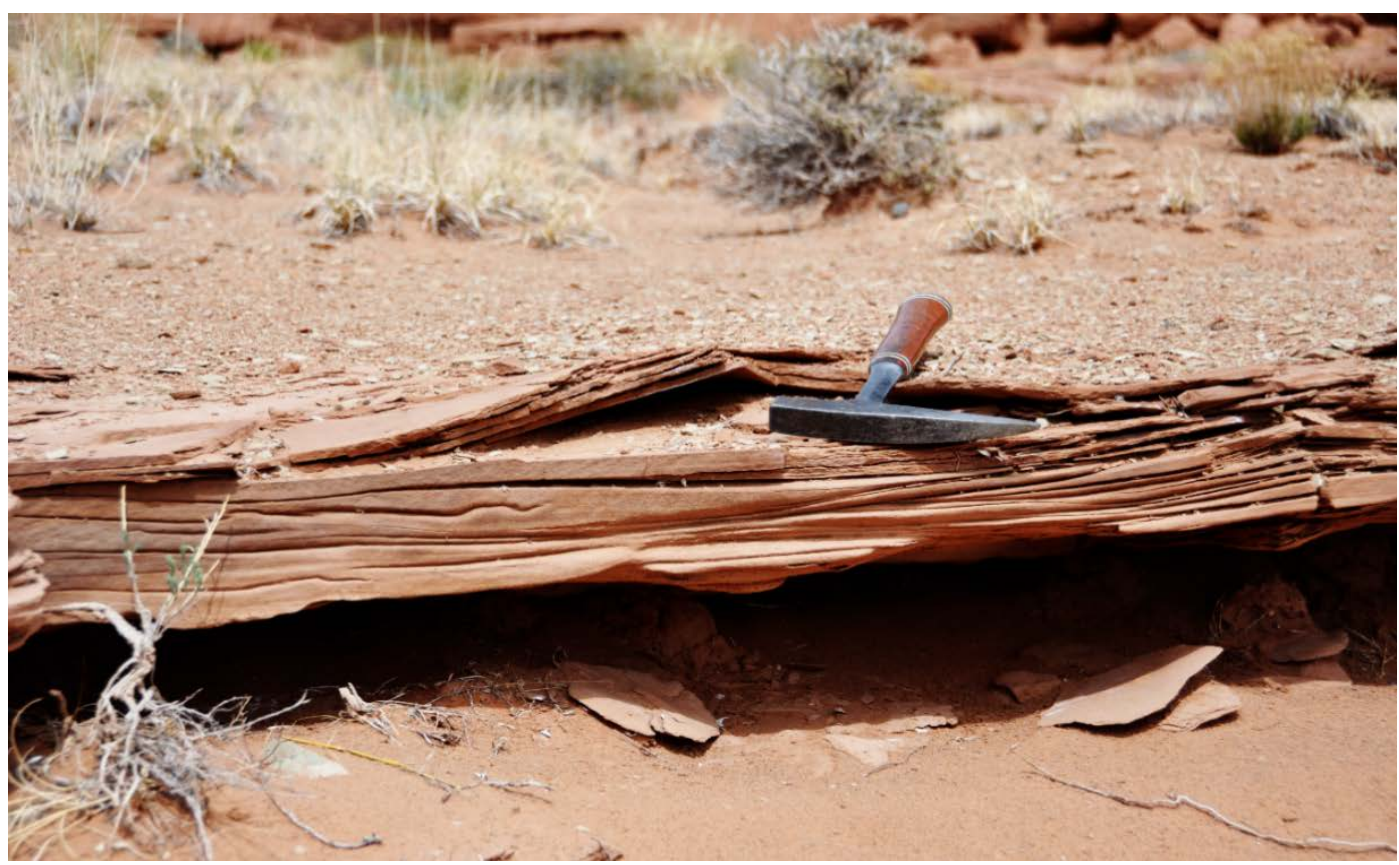

Figure 24. Stable antidunes. This facies is exemplified by relatively stable supercritical flow just above planar lamination conditions. Hydraulic jumps are small, allowing deposition of small migrating antidunes. These are preserved as thin, lensoidal packages of sediment. In essence, this facies represents the boundary between well formed antidunes and planar lamination, resulting in "smeared" features.

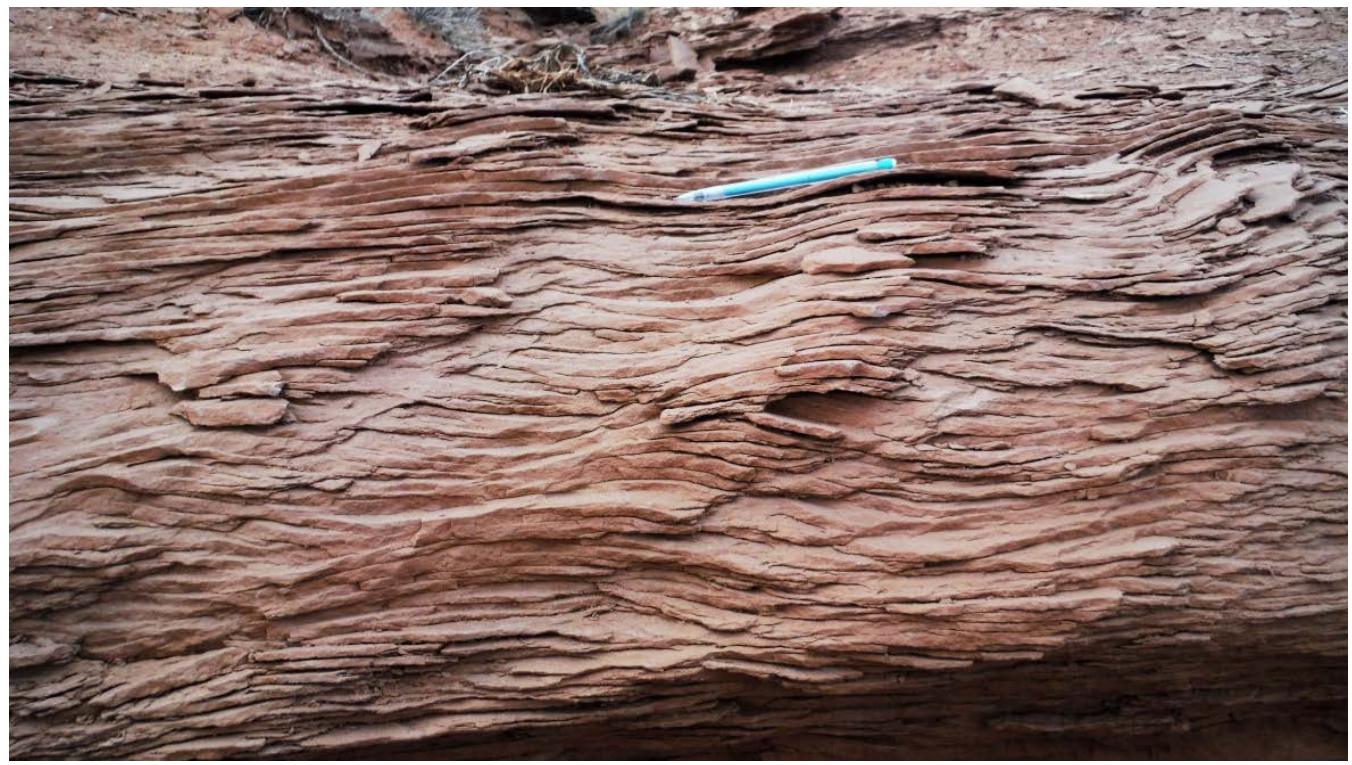

Figure 25. Aggrading antidunes. This facies indicates less-stable supercritical flow conditions, with larger hydraulic jumps. This allows for more sedimentation, including larger and better preserved antidunes. In this photo, multiple wavelengths are visible, with limited reworking of inactive bedforms by new ones. This suggests that high sedimentation rates dominated, likely due to high sediment loads. Flow is to the left. 


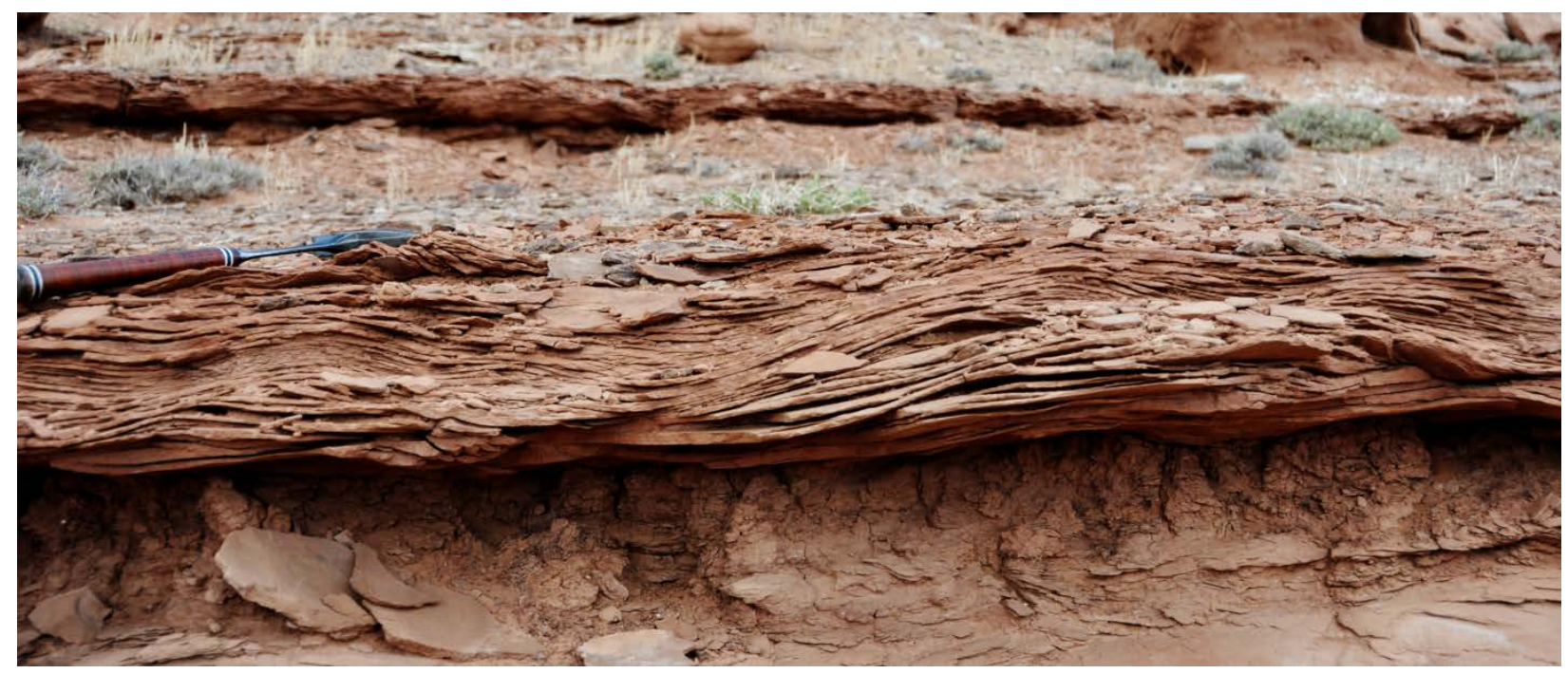

Figure 26. Climbing antidunes. This facies is formed under similar conditions as unstable antidunes, except under even higher sedimentation rates. This could be the result of higher sediment loads, or standing waves. Where hydraulic breaks linger in one location, multiple laminations build in the same location, with limited upstream migration. Flow is to the left.

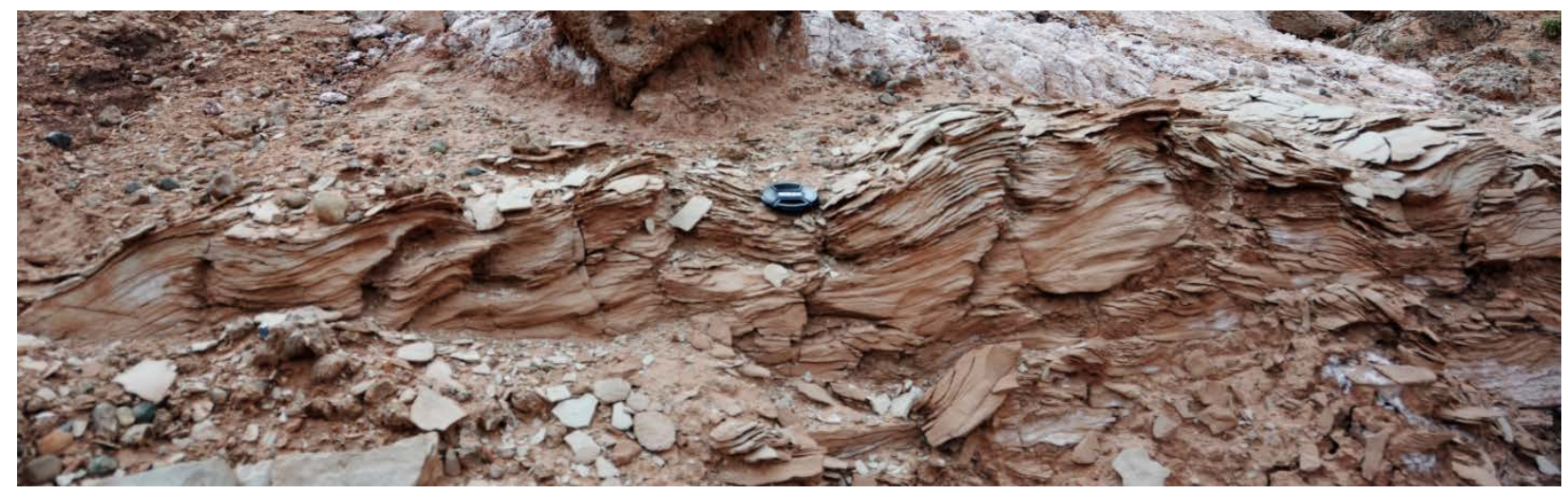

Figure 27. Aggrading chutes and pools. This facies represents another increase in Froude number, where hydraulic jumps increase in magnitude. At this point, hydraulic jumps form relatively deep "pools" at the bottom of steep "chutes", or steeply dipping zones of resumed supercritical flow downstream of the previous hydraulic jump. While the overall morphology of the chutes and pools in this outcrop match that described by Cartigny et al. (2013), internal structures are different here. Instead of bundles of antidunal bedforms that interfere with each other, this outcrop exhibited consistently parallel internal lamina that are traceable from pool to chute to pool. This may be another indicator that some environments within the study interval experienced exceptionally high sedimentation rates, which prevented active bedforms from reworking previously deposited sediments. Located at $38^{\circ} 54^{\prime} 3.47^{\prime \prime} \mathrm{N}$ $111^{\circ} 1$ '26.66" W. 


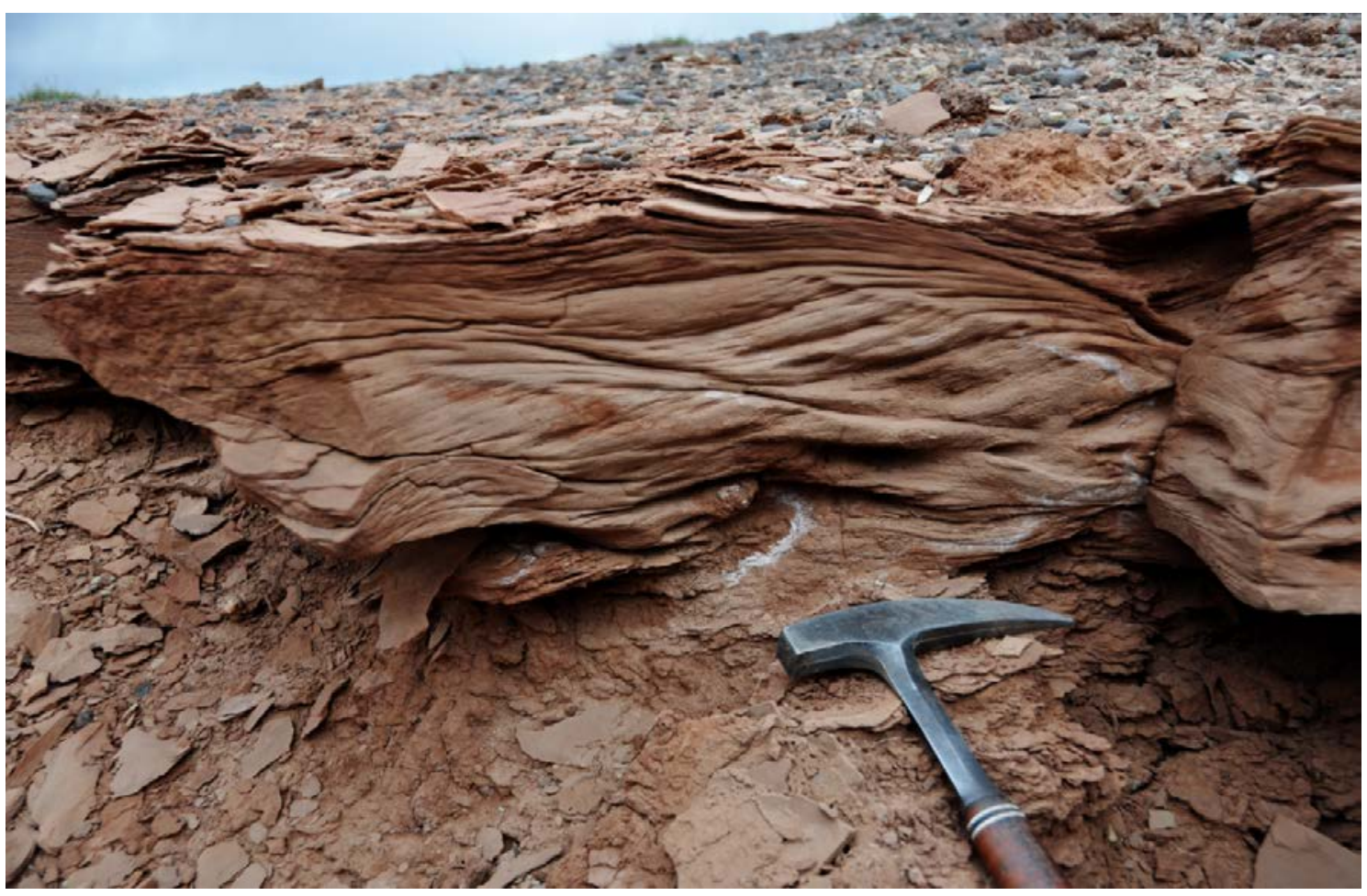

Figure 28. Cyclic steps. This facies represents the highest stage of flow criticality according to Cartigny et al. (2013). Large hydraulic jumps are separated by relatively long intervals of supercritical flow, which deposit gently upstream dipping convex-upward laminae. Flow is to the right. These bedforms represent some of the highest stage flow conditions described in the literature. Located at $38^{\circ} 54^{\prime} 3.47^{\prime \prime} \mathrm{N} 111^{\circ} 1^{\prime} 26.66^{\prime \prime} \mathrm{W}$. 


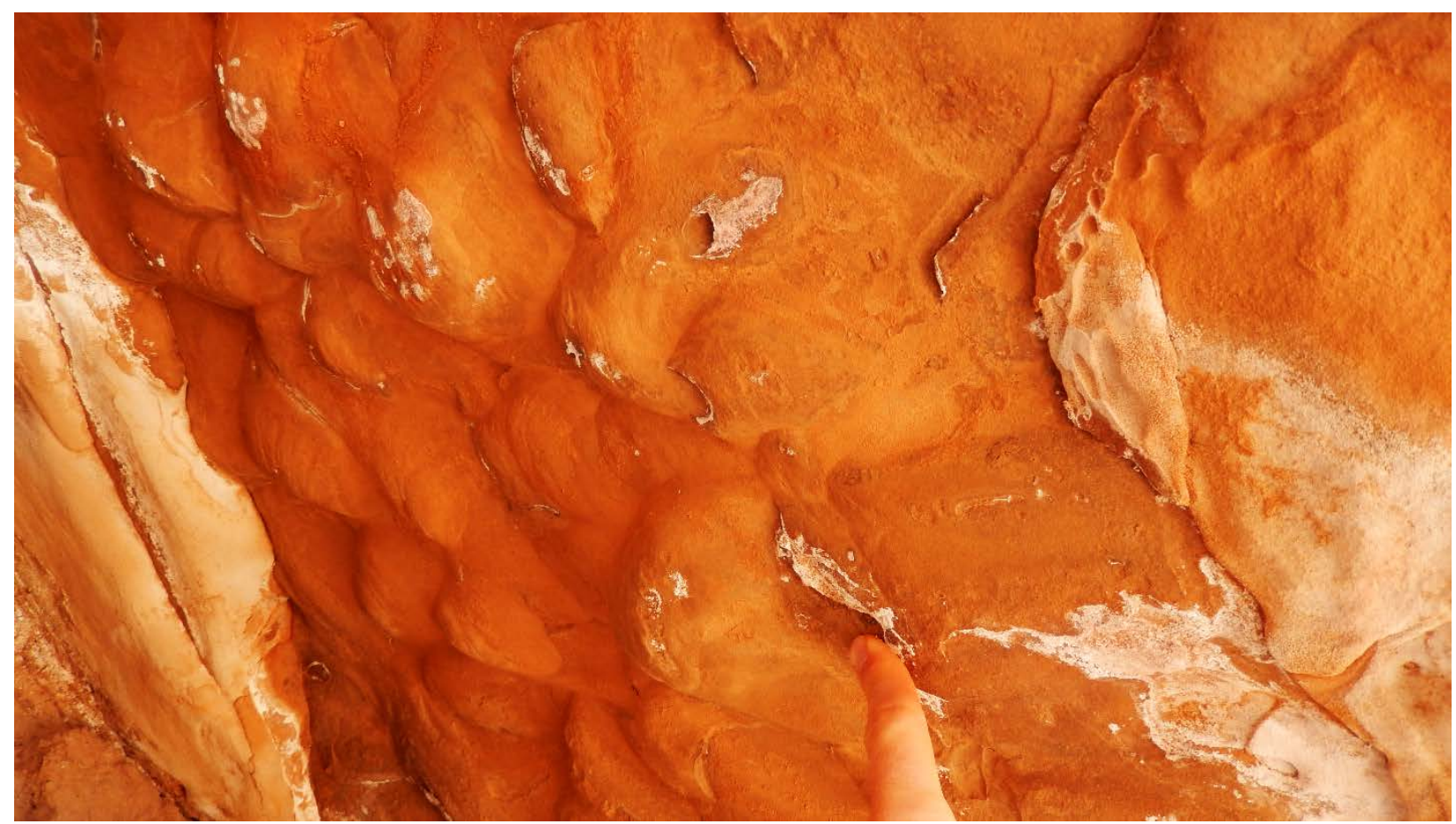

Figure 29. Flute casts. Example of a sandstone sheet with a heavily scoured basal contact. Flute casts flare towards the upper-left of the photo, indicating flow in that direction. Photo taken near the Moore Road south section.

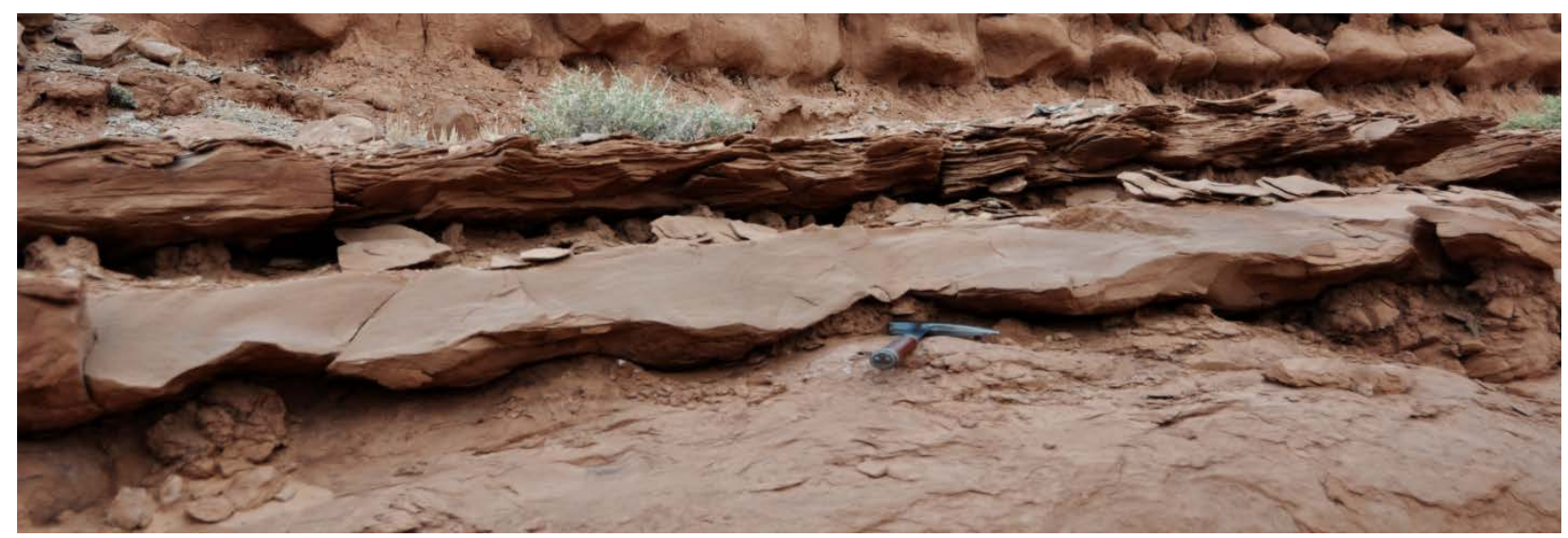

Figure 30. Symmetrical scours. The erosional basal contact of the unit just above the hammer in the center of the photo can be described as symmetrical or sinusoidal. This is interpreted to represent an upper flow regime erosive event. 


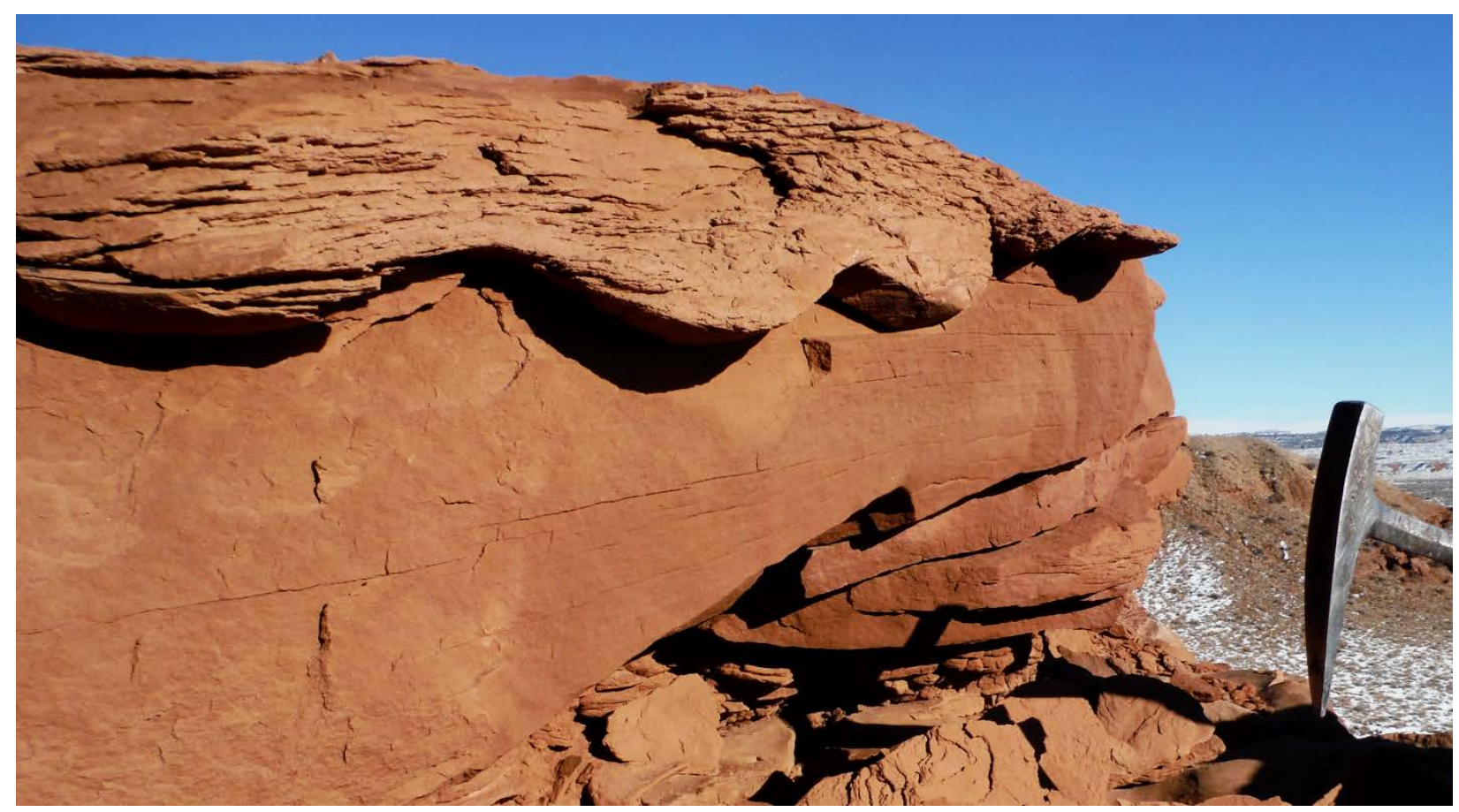

Figure 31. Symmetrical scours. Note symmetrical scouring pattern along the top of the planar-laminated bed in the center of the photo. 


\section{Facies Association A - Sabkha}

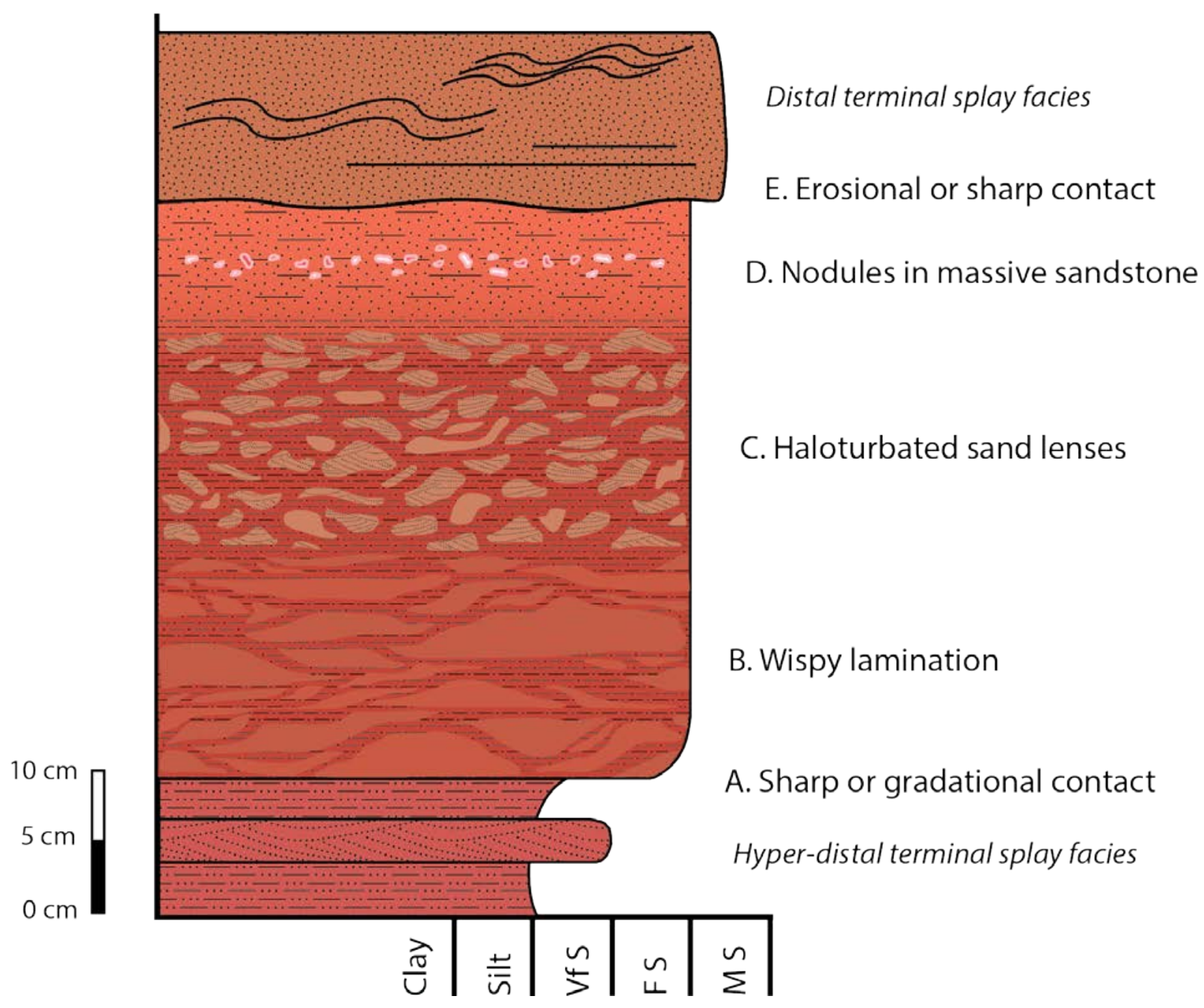

Figure 32. Facies Association A - Sabkha. Beginning with either a sharp or gradational contact, this facies association is dominated by salt crust textures. These include large $(4-10 \mathrm{~cm})$ and small $(1-4 \mathrm{~cm})$ haloturbated sand lenses that may or may not demonstrate banding or solution loading. Massive cleaner sandstone facies often host quartz-replaced salt nodules, ranging in size from coarse sand-sized to several centimeters in diameter. The order of appearance of intervals of different sized sand lenses and nodules was variable, and the order shown here does not imply a repeated trend. Basal contact of the overlying unit is commonly erosional or sharp for distal terminal splay facies, but other unit types are seen just as often, with variable contact morphology. Ash beds are included in this facies association, but not in the facies model as they represent a rare regional event with little to do with local depositional processes and conditions. 


\section{Volcanic Ash}

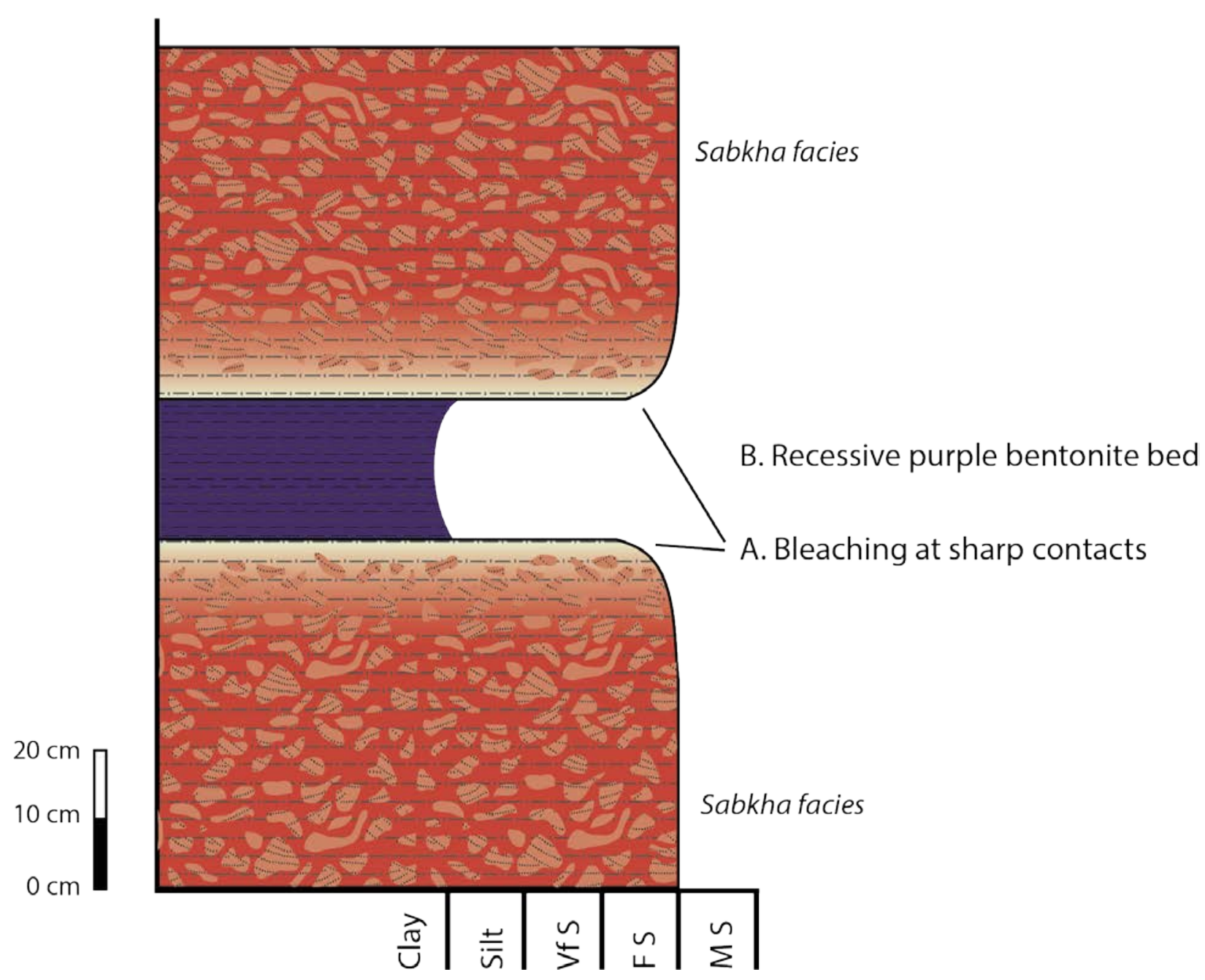

Figure 33. Volcanic Ash within sabkha facies association. Bleaching is caused by chemical reactions between the volcanic material and the surrounding sandstone. Ash components, including glass and fine-grained minerals, weather into expanding smectite clays, broadly termed bentonite. While only one ash bed was observed throughout the study interval, (with the exception of the I-70 section), if an ash fall event occurred in a location experiencing anything other than sabkha conditions, the more active processes of other depositional environments would have likely reworked the ash, removing evidence of the event. Therefore it is likely that ash beds were preferentially preserved in the sabkha facies association (A), which lacked an effective erosional process. 


\section{Facies Association B - Overbank Splay/ Paleosol}

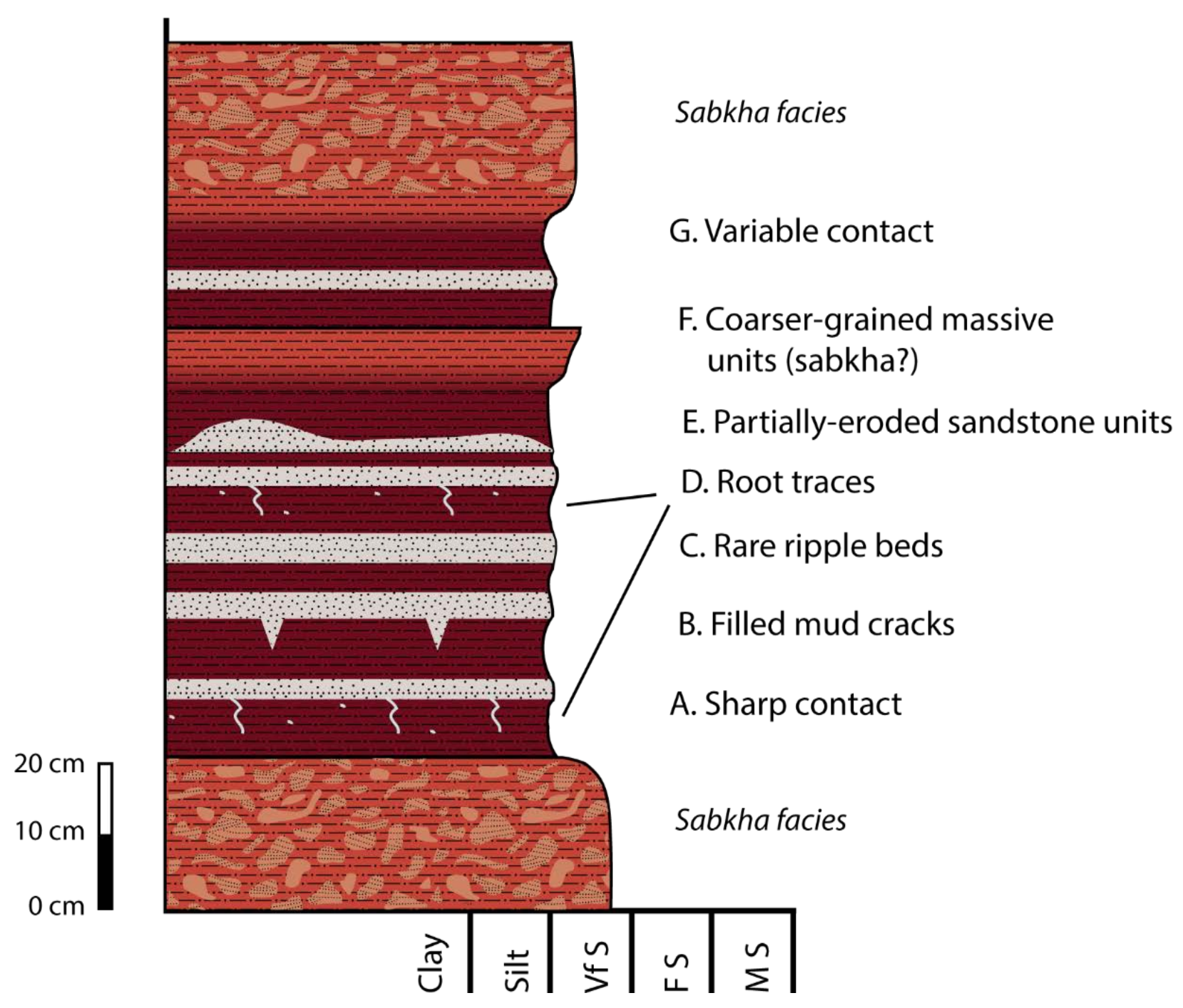

Figure 34. Facies Association B - Overbank splay/paleosol. This facies association typically begins with a sharp basal contact, followed by interbeds of dark red mudstone with varying but significant clay content and bleached sandstone beds and lenses. Mud crack and root trace facies punctuate the otherwise structureless mudstone units. These are made visible by the in-filling of voids with white sandstone of the interbedded units, or bleaching by decomposing organic material. In several locations, sandstone units have been heavily eroded, and may pinch and swell. In pinched areas they may be completely removed. In swell areas they may be as thick as $0.5 \mathrm{~m}$. This variation may exist within $1 \mathrm{~m}$ of lateral distance. Some facies associations hosted coarser-grained massive units, likely representing periods of sabkha salt crust development within the overbank environment. Contact of this association with overlying units and associations was variable. Observed contact type varied from gradational to scoured, and overlying facies associations varied from sabkha to distal and hyper-distal terminal splay, respectively. 


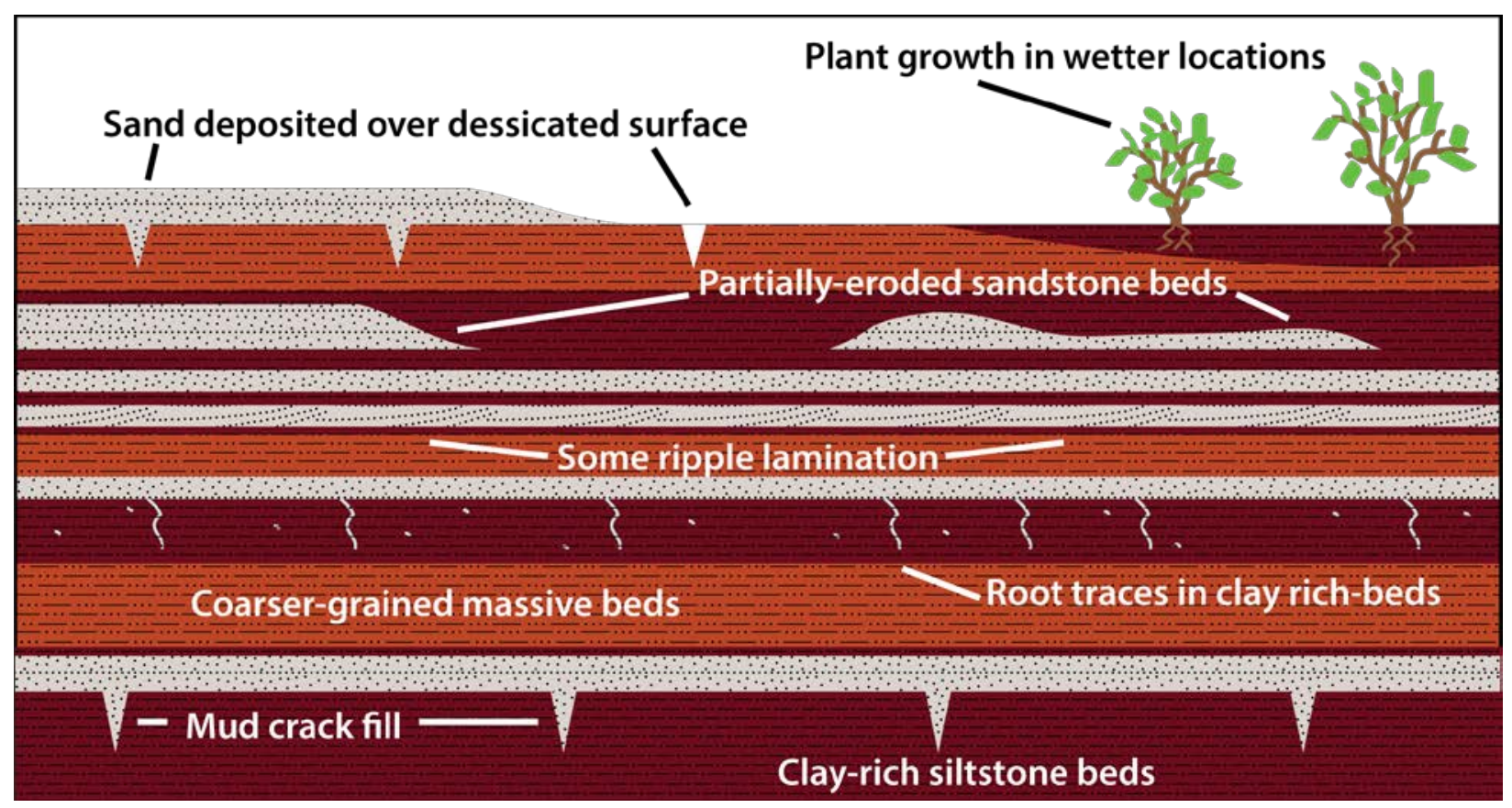

Figure 35. Development of overbank splay and paleosol packages. Areas of low topography within fluvial terminal splay systems serve as shallow ponding basins, where finer-grained sediment settles out of post-flood standing water. Drying periods are marked by mud cracks, and conditions conducive to plant growth are marked by root traces, visible as points (horizontal roots) and vertical, somewhat sinuous lines (vertical roots). Subsequent floods or advances of small eolian bedforms, bring small volumes of sand, which fill mud cracks, and deposits thin units of structureless or rippled sand. Decomposition of organic material from plant roots likely caused the bleached root traces. These sandstone units were the lightest-colored in the study interval, and are interpreted to be the result of bleaching, as organic material in the fine-grained sediments of overbank splays and paleosols decomposed and oxidized. 


\section{Facies Association C - Distal Terminal Splay}

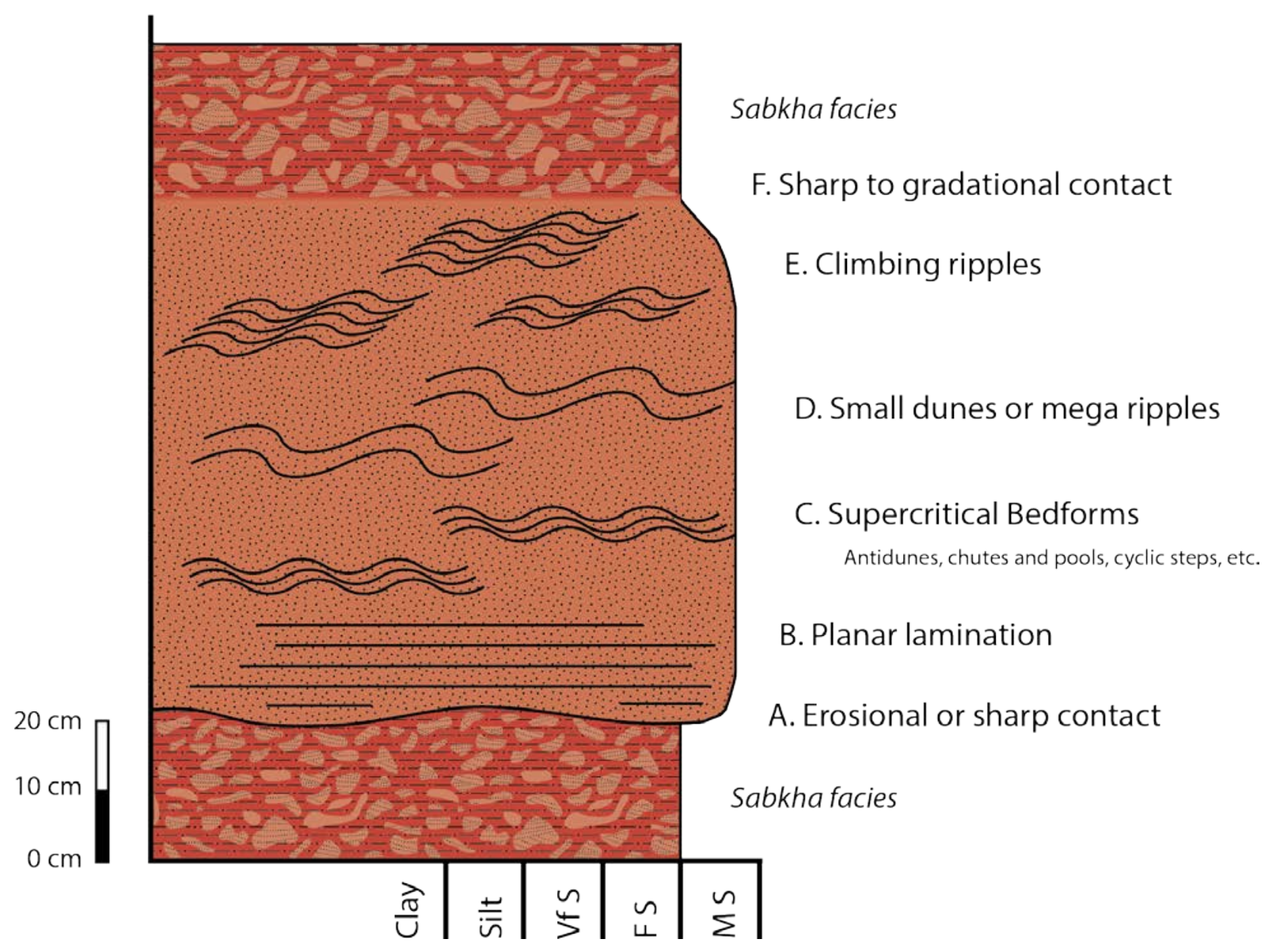

Figure 36. Facies Association C - distal terminal splay. This facies association hosts the best-preserved primary sedimentary features found within the study area. Beginning with a sharp contact, which is typically erosional, and sometimes includes flute casts, a broad range of facies deposited under varying flow conditions follow. These facies were found within very fine- to lower medium-grained sandstone units. While trends were observed regarding the order of facies successions, not all elements of a succession were found in every unit. A typical succession of primary facies begins with a scoured contact, followed by planar lamination, sub-planar lamination, antidunes, mega ripples or small dunes, and ends with climbing ripples, mega ripples, or small dunes. Sandstone beds hosting this facies succession are the most resistant within the study interval, and overlying beds always recede back, leaving varying amounts of the upper surface of these beds exposed. The interpreted depositional environment is a distal fluvial channel of a fluvial terminal splay. Stream flow would have been characterized by sudden, rapid, and sediment-laden flows that move through variable phases of scour, increasing velocity, and decreasing velocity. 

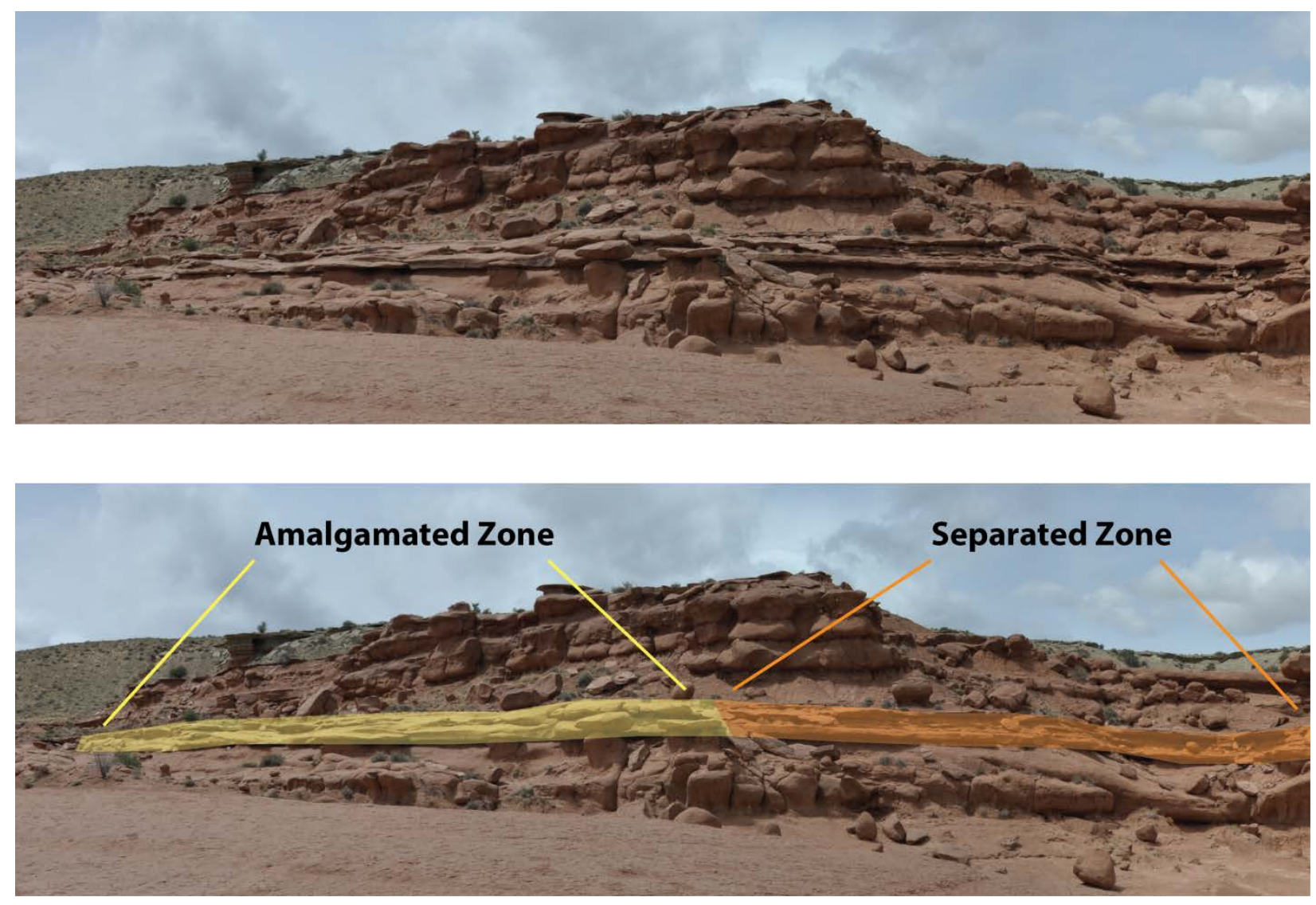

Figure 37. Amalgamating sandstone units. This interval of sandstone units was found to be continuous over more than half a kilometer (when it continued past the next cliff which offered very poor access). The total interval thickness was measured over $360 \mathrm{~m}$, and was found to maintain a consistent thickness of between 203 and $220 \mathrm{~cm}$. Located at $38^{\circ} 55^{\prime} 31.08^{\prime \prime} \mathrm{N} 110^{\circ} 0$ ' $28.77^{\prime \prime} \mathrm{W}$. 


\section{Facies Association D - Hyper-distal Terminal Splay}

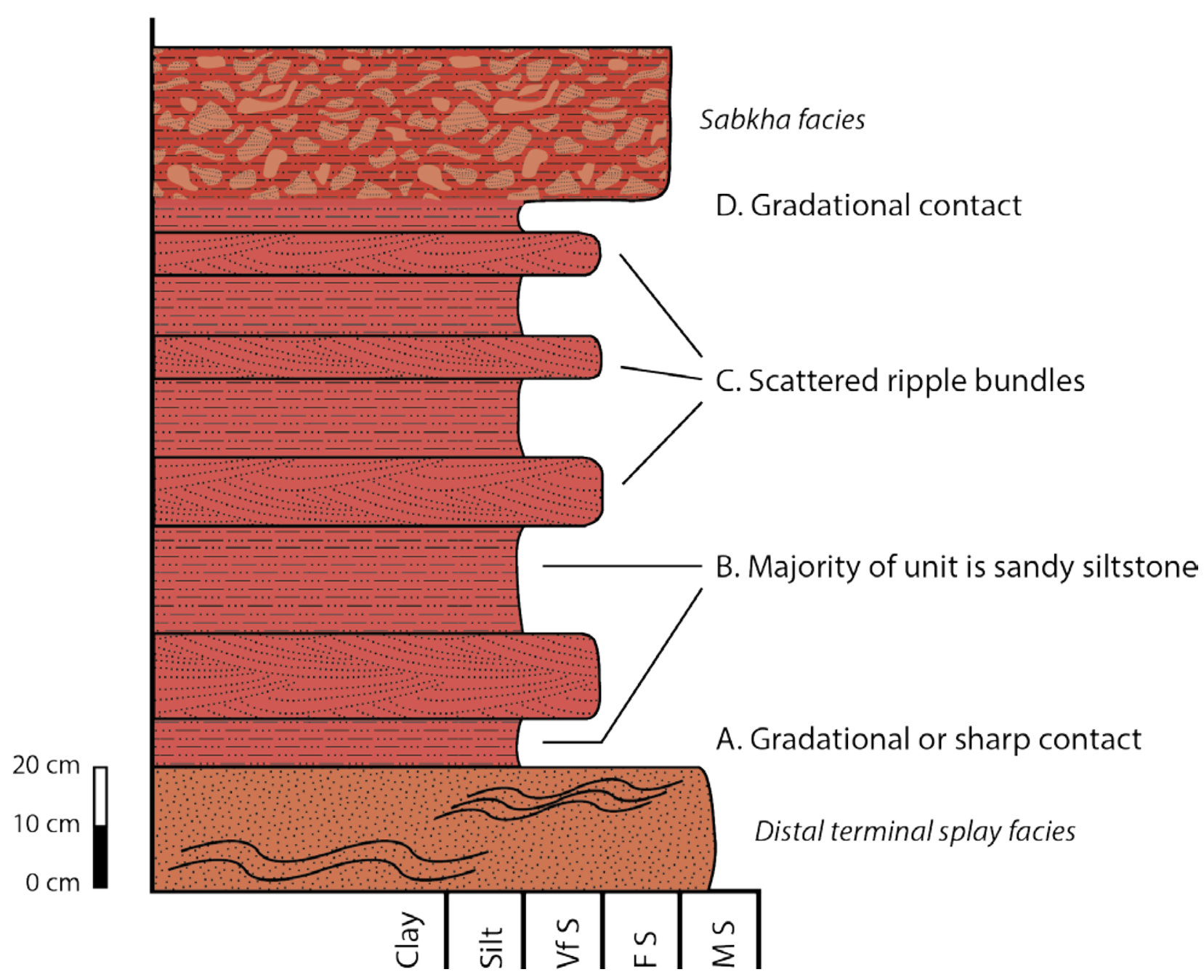

Figure 38. Facies Association D - Hyper-distal terminal splay. This facies association is dominated by slopeforming siltstones, with sporadically dispersed, thin, rippled sandstone beds. These sandstone beds are described as "ripple bundles" due to wide variability in bed thickness and the number of ripple trains found stacked above one another. No trends in bed thickness or spacing between beds was observed. Basal contacts with this facies association was typically sharp, and when capped by sabkha or overbank splay/paleosol facies associations, gradational contacts were commonly observed. When capped by distal terminal splay facies associations, contacts were typically sharp. This association is interpreted to be the product of hyper-distal reaches of fluvial terminal splays. In this setting, flow sediment load likely became hyperconcentrated, especially in fine-grained material, preventing the development of bedforms. Only occasional higher energy or lower sediment load flows were capable of working sediment into ripple bedforms. See Facies Association D - Hyper-distal terminal splay for more detailed discussion. 


\begin{tabular}{|c|c|c|c|c|c|c|}
\hline & $\begin{array}{l}\text { Facies } \\
\text { Association }\end{array}$ & & \multirow[b]{2}{*}{$C$} & \multirow[b]{2}{*}{$\mathrm{D}$} & \multirow[b]{2}{*}{ (Ash) } & \multirow[b]{2}{*}{ Unknown } \\
\hline & A & $\mathrm{B}$ & & & & \\
\hline \multirow[t]{2}{*}{$1-70$} & $67.08 \%$ & $8.77 \%$ & $7.87 \%$ & $14.85 \%$ & $1.43 \%$ & \\
\hline & & & \multicolumn{2}{|c|}{$22.72 \%$} & & \\
\hline \multirow[t]{2}{*}{$\begin{array}{l}\text { Green River } \\
\text { Cutoff Road }\end{array}$} & $72.25 \%$ & $5.50 \%$ & $5.37 \%$ & $16.23 \%$ & $0.65 \%$ & \\
\hline & & & \multicolumn{2}{|c|}{$21.60 \%$} & & \\
\hline \multirow[t]{2}{*}{ Cedar Mesa } & $71.93 \%$ & $6.59 \%$ & $4.09 \%$ & $6.14 \%$ & $1.14 \%$ & $10.12 \%$ \\
\hline & & & \multicolumn{2}{|c|}{$10.23 \%$} & & \\
\hline \multirow[t]{2}{*}{$\begin{array}{l}\text { Moore } \\
\text { Road South }\end{array}$} & $68.80 \%$ & $10.94 \%$ & $5.89 \%$ & $14.06 \%$ & $0.31 \%$ & \\
\hline & & & \multicolumn{2}{|c|}{$19.95 \%$} & & \\
\hline \multirow[t]{2}{*}{$\begin{array}{l}\text { Moore } \\
\text { Road North }\end{array}$} & $59.64 \%$ & $21.49 \%$ & $8.19 \%$ & $10.28 \%$ & $0.40 \%$ & \\
\hline & & & \multicolumn{2}{|c|}{$18.47 \%$} & & \\
\hline \multirow[t]{2}{*}{$\begin{array}{l}\text { Dutch Flat } \\
\text { North }\end{array}$} & $65.44 \%$ & $9.76 \%$ & $5.51 \%$ & $18.85 \%$ & $0.43 \%$ & \\
\hline & & & \multicolumn{2}{|c|}{$24.36 \%$} & & \\
\hline \multirow[t]{2}{*}{$\begin{array}{l}\text { Dutch Flat } \\
\text { South }\end{array}$} & $59.66 \%$ & $14.82 \%$ & $5.39 \%$ & $18.78 \%$ & $1.35 \%$ & \\
\hline & & & \multicolumn{2}{|c|}{$24.17 \%$} & & \\
\hline \multirow[t]{2}{*}{ AVERAGES } & $66.40 \%$ & $11.12 \%$ & $12.28 \%$ & $14.17 \%$ & $0.82 \%$ & \\
\hline & & & \multicolumn{2}{|c|}{$20.21 \%$} & & \\
\hline
\end{tabular}

Table 1. Volumetric percentages of facies associations (FA). Variation between sections is very limited, with most individual section percentages falling close to averages. One exception is found in the Moore Road North section, which had the lowest occurrence of the sabkha facies association (FA-A), and highest occurrence of overbank splay/paleosol facies association (FA-B). The other prominent exception is found in the Cedar Mesa section, where occurrence of distal and hyper-distal terminal splay facies associations (FA-C and FA-D) were half that of the study average. Some or all of this disparity may be the result of $10.12 \%$ of the outcrop at Cedar Mesa being covered by thick alluvium, which prevented facies identification. Since siltstone facies of FA-D were found to be slope-formers, it is possible that these units did indeed occur in the normal frequency, but the resulting slopes accommodated too much alluvium to be properly identified. Gray cells represent the combined percentage of FA-C and FA-D, which were grouped together under the interpretation that they result from similar depositional processes in the same or similar flow events. When these associations were combined, they exhibited the least variation in volumetric percentage of any other facies association (excluding the Cedar Mesa section). 


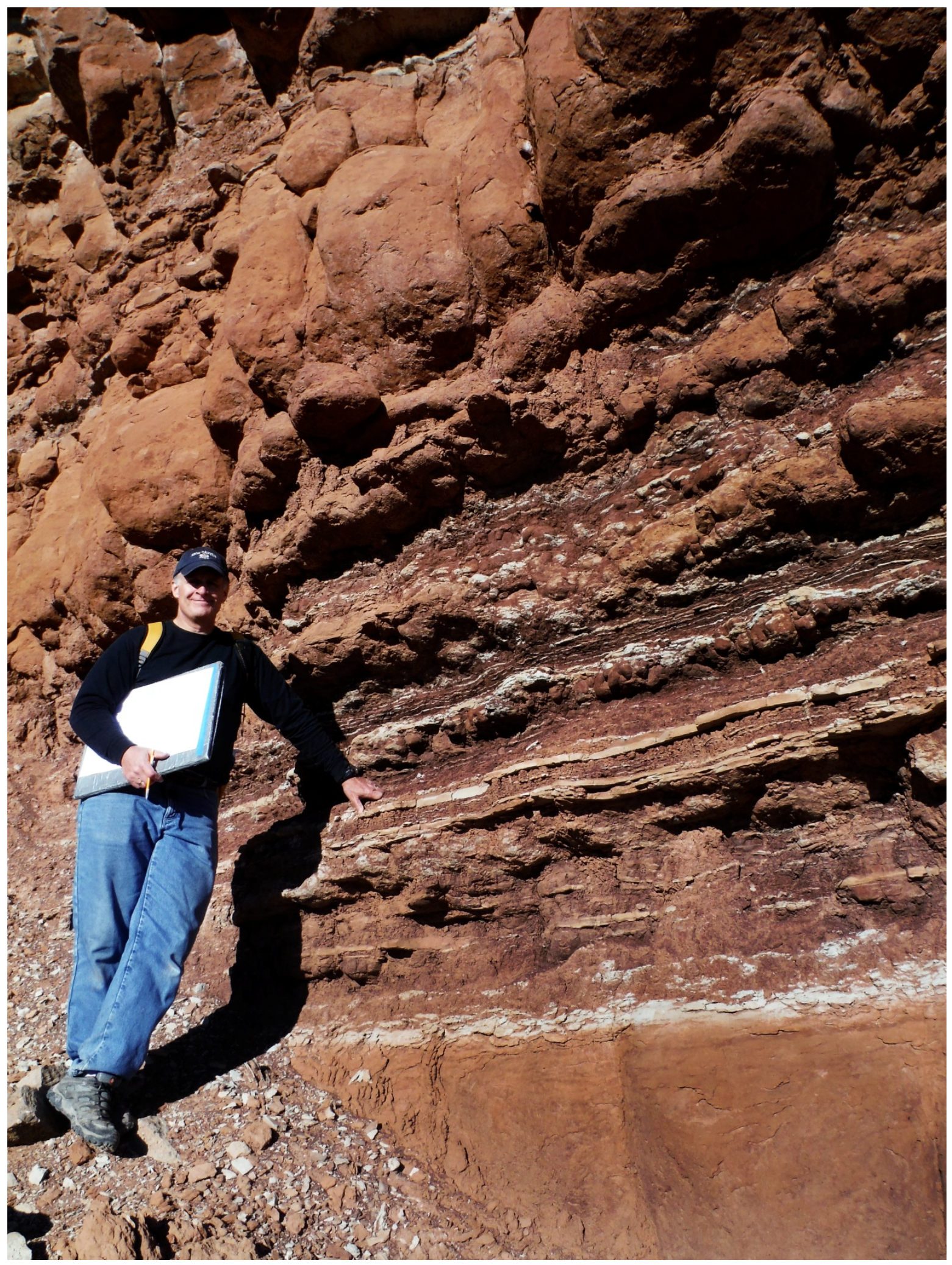

Figure 39. Coarsening upward succession of facies associations A and B. Note darker, more recessive units tend to coarsen and lighten upwards. This likely indicates transitional conditions between overbank splay/ paleosol and sabkha environments. 


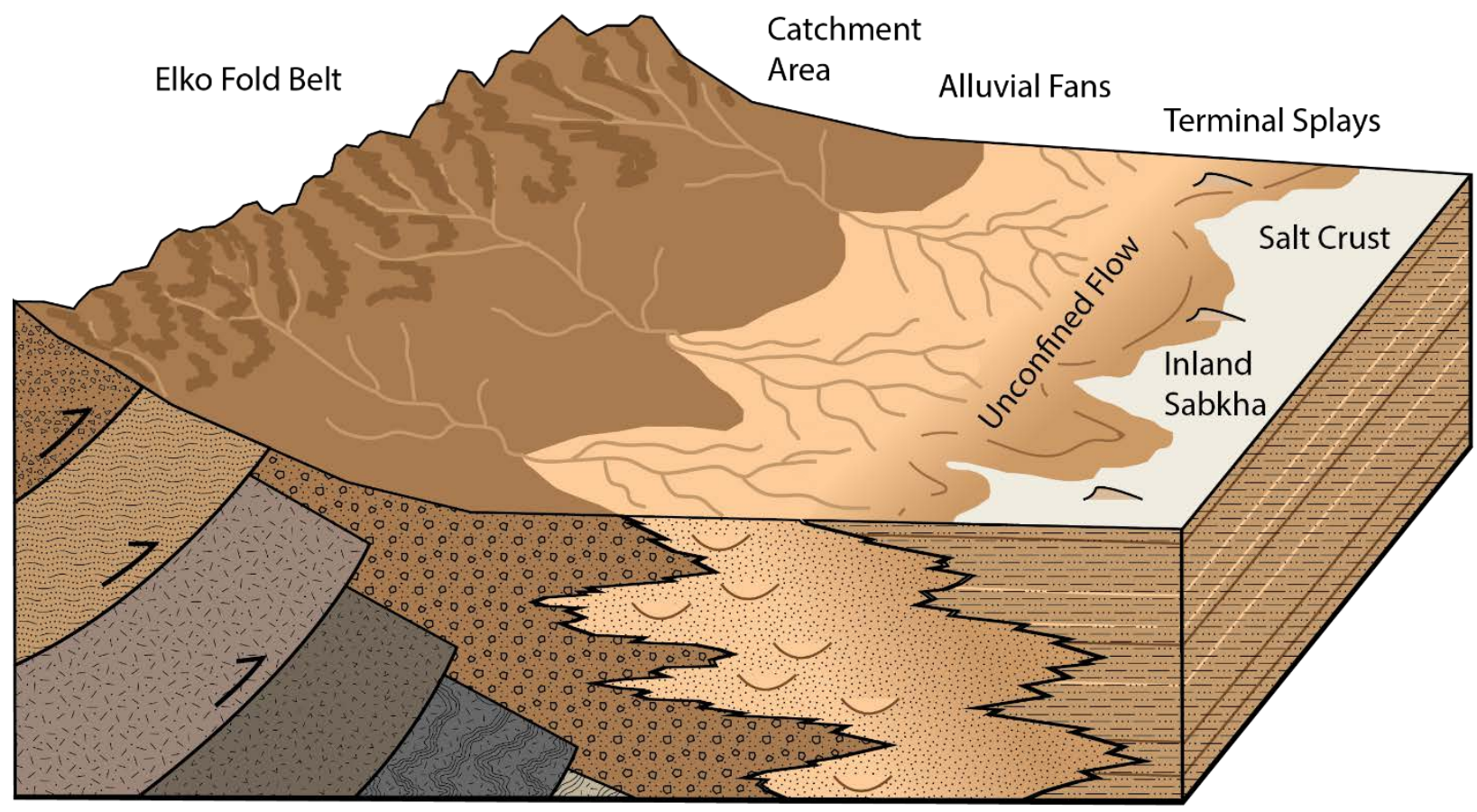

Figure 40. Regional cross-section of the sedimentary system of the upper Entrada Sandstone. A compressional tectonic regime created the Elko Fold Belt. Crustal loading associated with this orogeny also created a foreland basin to the east of the fold belt. Uplifted continental crust was exposed and eroded, with the resulting sediment being transported downslope and accommodated by the basin. Extremely arid conditions resulted in ephemeral stream flow within the alluvial system. This arid climate, coupled with a eustatic sea-level low, resulted in a basin center devoid of permanent standing water. A high water table allowed evaporation of groundwater, producing a salt encrusted surface within an inland sabkha environment. As ephemeral stream flow reached the low topography of the central basin inland sabkha, flows broadened, shallowed, and terminated in fluvial terminal splays. Continued uplift of the fold belt likely affected pro- and retrogradation of terminal splays onto the sabkha, as erosional rates fluctuated and interacted with changes in accommodation. This study identified facies belonging to distal and hyperdistal terminal splay zones, in addition to sabkha facies. Cross-sectional view of alluvial fans includes channels closer to the hinterlands, or in up-slope positions, while the basinward extent of alluvial fans include interfingered terminal splay and sabkha sediments. Scattered sand dunes are depicted on this cross-section, as several eolian dune facies units were observed, although they were rare and not encountered within a measured section. These are likely composed of the same siliciclastic material that was incorporated into sabkha salt crusts, forming dunes when enough sediment was accumulated. Modified from Hubert and Hyde, 1982. 


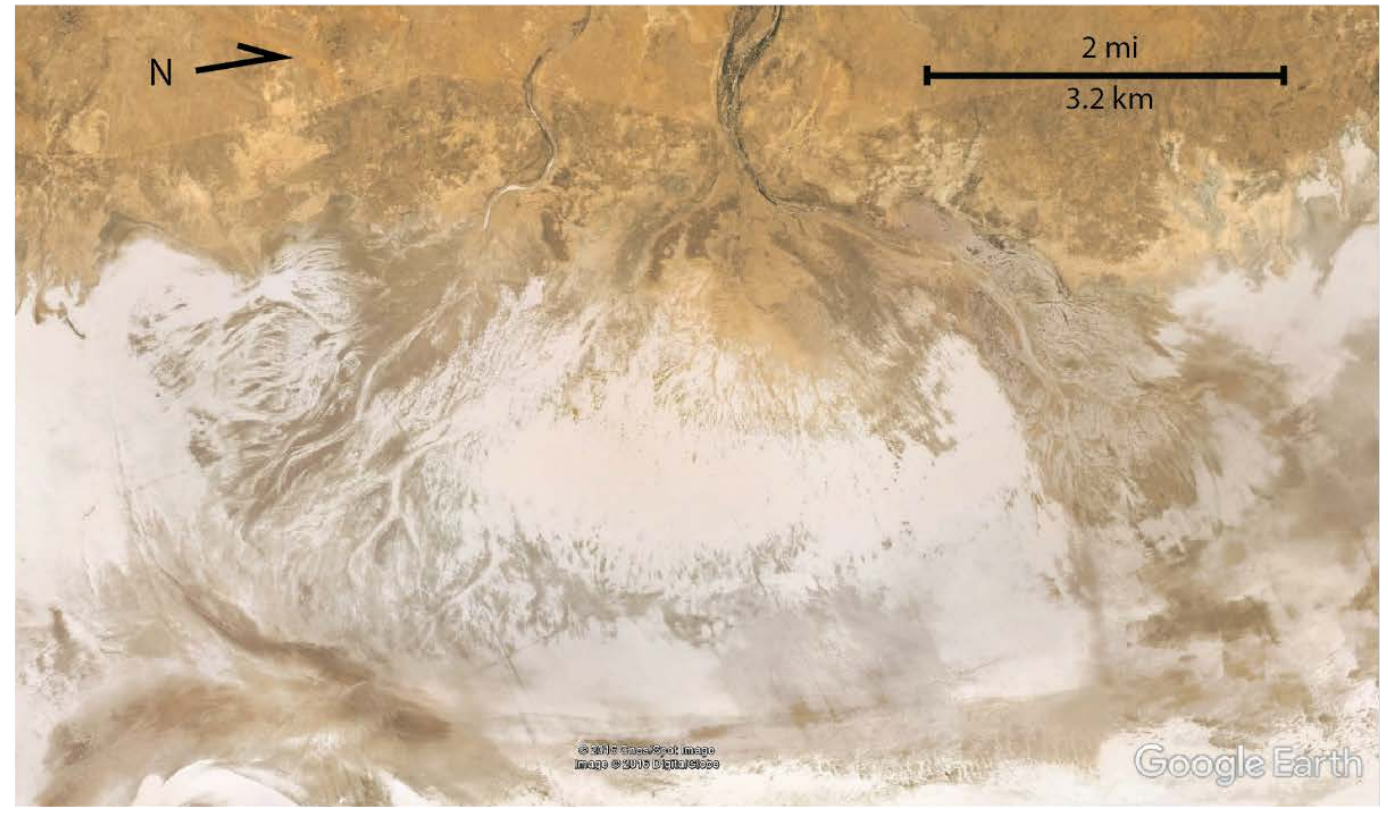

A.

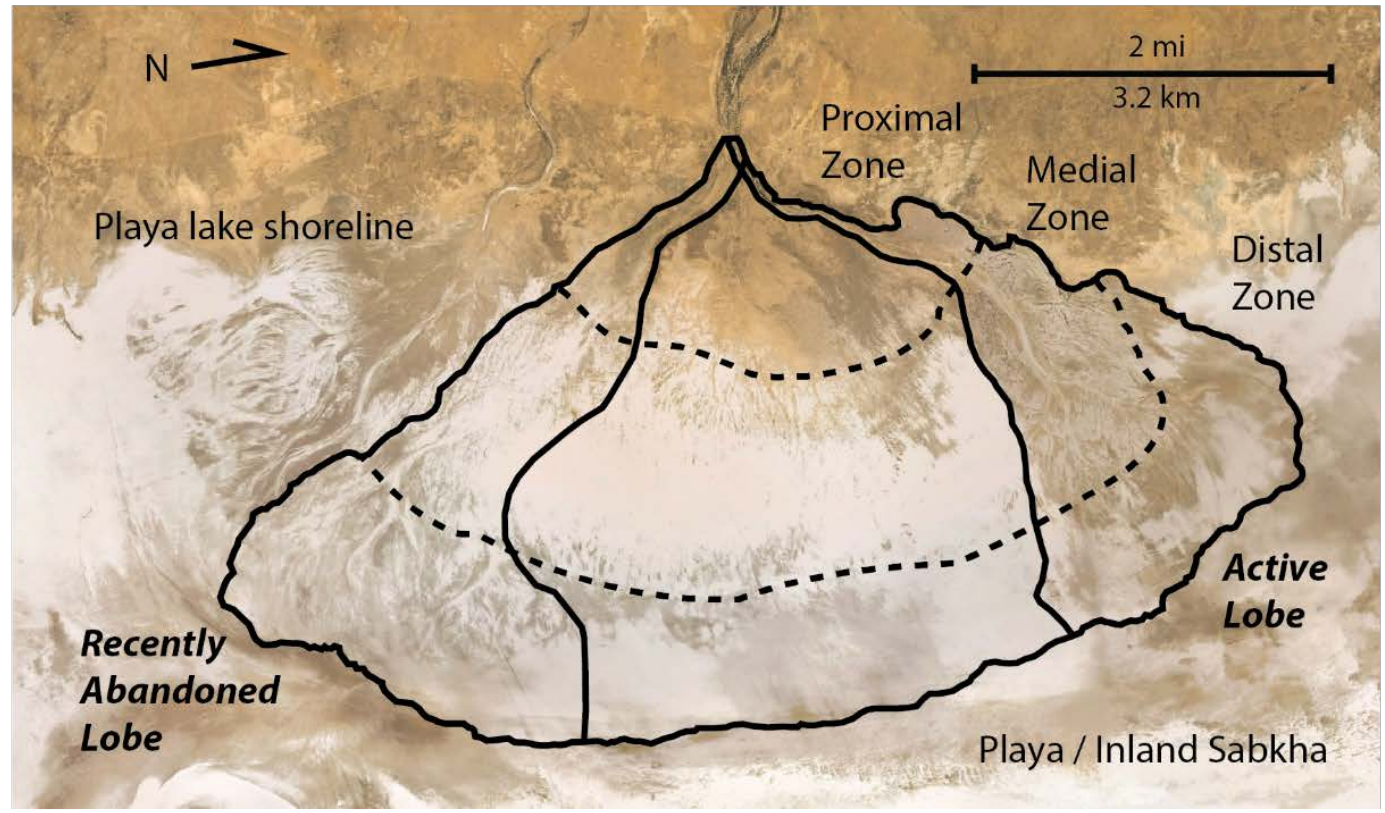

B.

Figure 41. Satellite imagery of a terminal splay in Lake Frome, Australia. A. Original Cnes/Spot image taken from Google Earth. B. Terminal splay features are annotated, including the active and recently abandoned lobes, as well as the proximal, medial, and distal zones. These zones host unique facies assemblages representing different flow conditions (Figure 42). The relative ages of individual lobes can be estimated by color: lighter colors are the result of thicker salt crust, indicating prolonged absence of fluvial influence. 


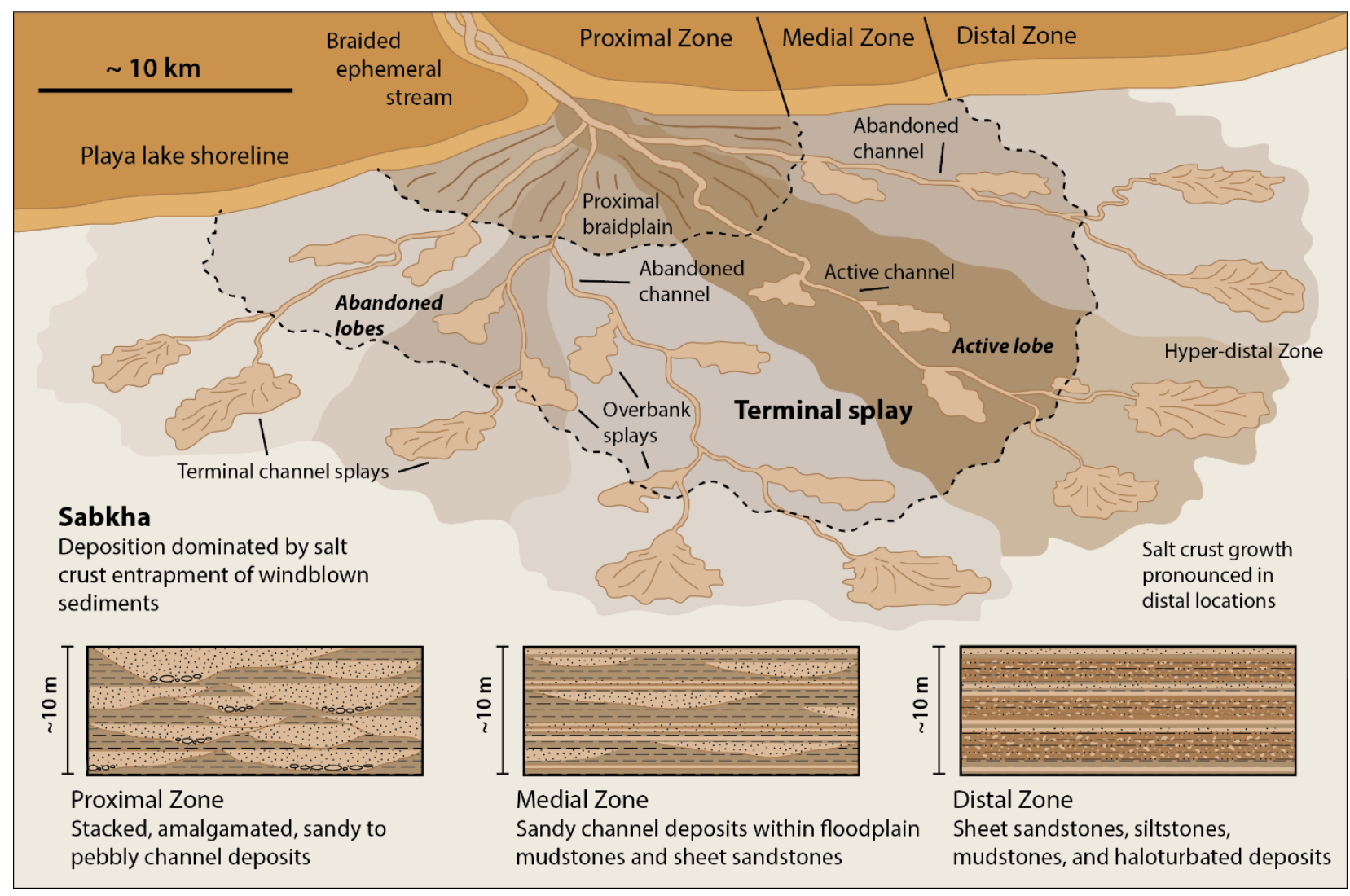

Figure 42. Alluvial fan terminal splay architecture. In this model, an ephemeral stream entering a sabkha experiences a transition from channelized flow to unchannelized flow. The resulting terminal splay can be divided into genetically- and time-related wedges, or lobes. As sedimentation from one or more flow events deposits enough sediment, channels are choked or dammed, and avulsion occurs as flows seek a new path. As time passes without fluvial interference, sabkha processes of groundwater evaporation and salt crust efflorescence (growth of crystals on a surface) resume. From a physical sedimentological viewpoint, a terminal splay can be divided into proximal, medial, and distal zones, based on unique assemblages of bedforms, sedimentary features, surfaces, and grain-size distributions. Modified from Nichols and Fisher, 2007. 


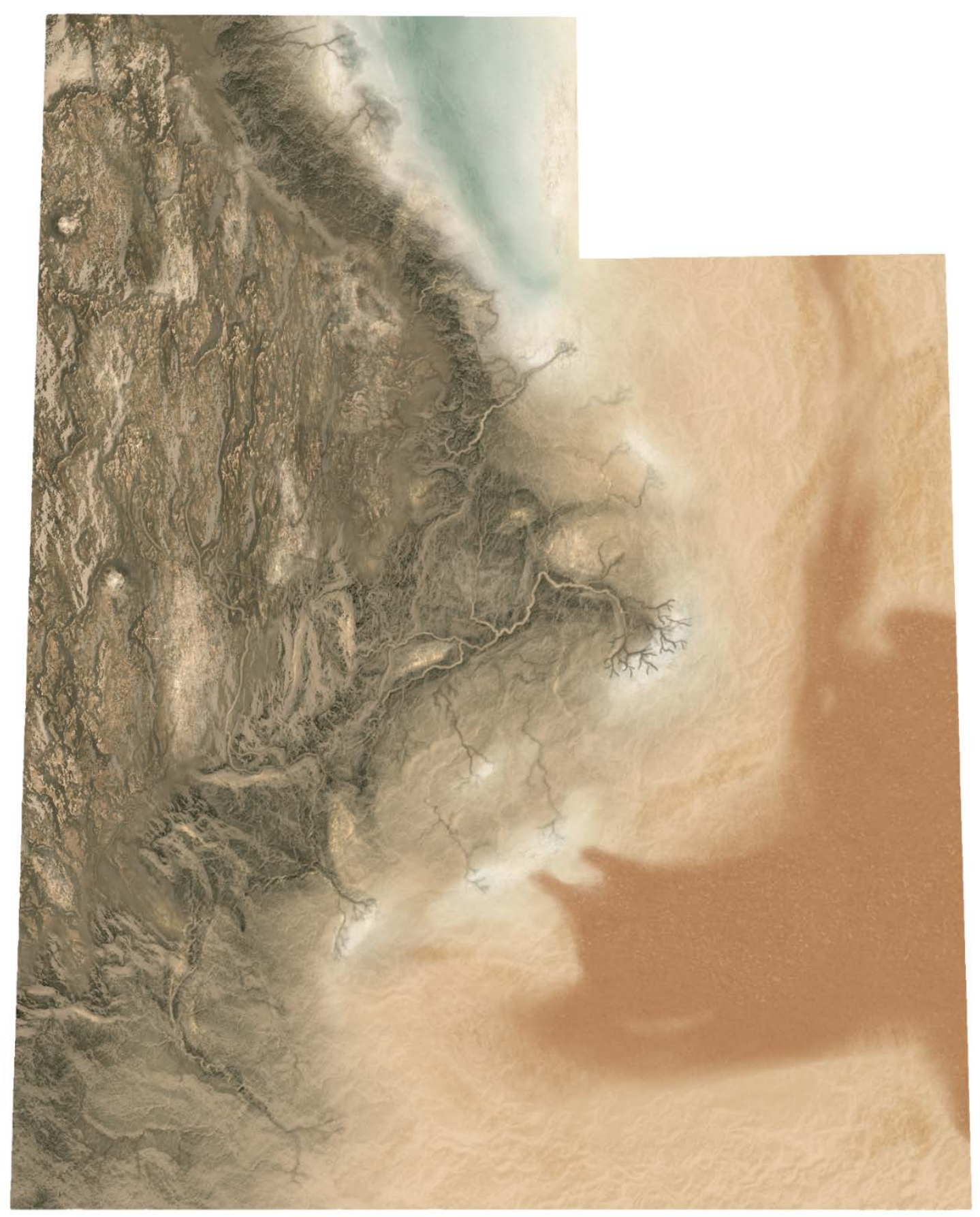

Figure 43. Paleogeographic reconstruction of Utah during the Middle Jurassic Callovian time. The Elko Fold Belt is the sediment source for alluvial systems entering the associated foreland basin. The Entrada Erg is depicted by oxidized dune fields, and active sabkha is shown as salt-whitened locations between the fold belt and erg. As inland sabkhas develop through evaporation of shallow groundwater, they are indicative of the lowest topography of an arid basin. These topographic lows also accommodate the few fluvial systems that make their way through the alluvial plain out to the basin center. In times of greater sea level or precipitation, these fluvial systems would reach standing water in basin centers, and create deltas, as is shown in the northern extreme of this map. Further south, fluvial systems terminate in an inland sabkha environment, creating terminal splays. This study interprets the upper Entrada as an interfingered sabkha and terminal splay system, depicted in the center of this reconstruction. From Morris et al., 2016. 


\section{APPENDIX A}

Measured section data, including location coordinates, thicknesses (cm), and facies assignments.

\begin{tabular}{|c|c|c|c|c|c|c|}
\hline \multirow{2}{*}{$\begin{array}{l}\text { I-70 } \\
38^{\circ} 50^{\prime} 46.37^{\prime \prime} \mathrm{N} \\
111^{\circ} 5^{\prime} 51.28^{\prime \prime} \mathrm{W} \\
\text { Unit \# } \\
\end{array}$} & \multicolumn{5}{|c|}{ Facies Association } & \\
\hline & A & B & $\mathrm{C}$ & $\mathrm{D}$ & (Ash) & \\
\hline 1 & & & & 190 & & \\
\hline 2 & 170 & & & & & \\
\hline 3 & 20 & & & & 20 & \\
\hline 3 & 600 & & & & & \\
\hline 5 & & 30 & & & & \\
\hline 6 & 25 & & & & & \\
\hline 7 & & 15 & & & & \\
\hline 8 & & & & 190 & & \\
\hline 9 & 350 & & & & & \\
\hline 10 & & 45 & & & & \\
\hline 11 & 130 & & & & & \\
\hline 12 & & & & 35 & & \\
\hline 13 & 20 & & & & & \\
\hline 14 & & 20 & & & & \\
\hline 15 & & & 80 & & & \\
\hline 16 & 205 & & & & & \\
\hline 17 & & 35 & & & & \\
\hline 18 & & & 140 & & & \\
\hline 19 & & & & & 20 & \\
\hline 20 & 375 & & & & & \\
\hline 21 & & 100 & & & & $\begin{array}{l}\text { Section } \\
\text { Total: }\end{array}$ \\
\hline Total Thickness $(\mathrm{cm})$ & 1895 & 245 & 220 & 415 & 40 & 2815 \\
\hline Percentage & $67.32 \%$ & $8.70 \%$ & $7.82 \%$ & $14.74 \%$ & $1.42 \%$ & \\
\hline Sum of Similar Facies & & $76.02 \%$ & & $22.56 \%$ & & \\
\hline
\end{tabular}




\begin{tabular}{|c|c|c|c|c|c|c|}
\hline \multirow{2}{*}{$\begin{array}{l}\text { Moore Road South } \\
38^{\circ} 54^{\prime} 4.41^{\prime \prime} \mathrm{N} \\
111^{\circ} 1^{\prime} 22.31^{\prime \prime} \mathrm{W} \\
\text { Unit \# }\end{array}$} & \multicolumn{5}{|c|}{ Facies Association } & \\
\hline & A & B & $\mathrm{C}$ & $\mathrm{D}$ & (Ash) & \\
\hline 1 & & & 15 & & & \\
\hline 2 & & & & 20 & & \\
\hline 3 & & & 35 & & & \\
\hline 4 & & & & 55 & & \\
\hline 5 & & & & 120 & & \\
\hline 6 & & & 20 & & & \\
\hline 7 & & & & 140 & & \\
\hline 8 & 130 & & & & & \\
\hline 9 & & & & & 10 & \\
\hline 10 & 550 & & & & & \\
\hline 11 & & 15 & & & & \\
\hline 12 & 536 & & & & & \\
\hline 13 & 40 & & & & & \\
\hline 14 & & & 45 & & & \\
\hline 15 & & & & 86 & & \\
\hline 16 & 419 & & & & & \\
\hline 17 & & 120 & & & & \\
\hline 18 & & & 23 & & & \\
\hline 19 & & 40 & & & & \\
\hline 20 & & & 52 & & & \\
\hline 21 & & 73 & & & & \\
\hline 22 & & 25 & & & & \\
\hline 23 & 60 & & & & & \\
\hline 24 & 182 & & & & & \\
\hline 25 & & & & 33 & & \\
\hline 26 & & 15 & & & & \\
\hline 27 & & 20 & & & & \\
\hline 28 & & 45 & & & & \\
\hline 29 & 304 & & & & & $\begin{array}{l}\text { Section } \\
\text { Total: }\end{array}$ \\
\hline Total Thickness (cm) & 2221 & 353 & 190 & 454 & 10 & 3228 \\
\hline Percentage & $68.80 \%$ & $10.94 \%$ & $5.89 \%$ & $14.06 \%$ & $0.31 \%$ & \\
\hline Sum of Similar Facies & & $79.74 \%$ & & $19.95 \%$ & & \\
\hline
\end{tabular}




\begin{tabular}{|c|c|c|c|c|c|c|}
\hline \multirow{2}{*}{$\begin{array}{l}\text { Moore Road North } \\
38^{\circ} 55^{\prime} 10.64^{\prime \prime} \mathrm{N} \\
111^{\circ} 0^{\prime} 41.55^{\prime \prime} \mathrm{W} \\
\text { Unit \# } \\
\end{array}$} & \multicolumn{5}{|c|}{ Facies Association } & \\
\hline & $A$ & $\mathrm{~B}$ & $\mathrm{C}$ & $\mathrm{D}$ & (Ash) & \\
\hline 1 & & 6 & & & & \\
\hline 2 & & & 25 & & & \\
\hline 3 & & 10 & & & & \\
\hline 4 & & & 55 & & & \\
\hline 5 & & & & 55 & & \\
\hline 6 & & & 15 & & & \\
\hline 7 & & & & 30 & & \\
\hline 8 & & 15 & & & & \\
\hline 9 & & 5 & & & & \\
\hline 10 & & & 30 & & & \\
\hline 11 & & 145 & & & & \\
\hline 12 & 152 & & & & & \\
\hline 13 & & & & & 10 & \\
\hline 14 & 596 & & & & & \\
\hline 15 & & 30 & & 15 & & \\
\hline 16 & & & 33 & & & \\
\hline 17 & & & & 155 & & \\
\hline 18 & 260 & & 18 & & & \\
\hline 19 & & 57 & & & & \\
\hline 20 & 28 & & & & & \\
\hline 21 & & 47 & & & & \\
\hline 22 & 84 & & & & & \\
\hline 23 & & 46 & & & & \\
\hline 24 & 19 & & & & & \\
\hline 25 & & 68 & & & & \\
\hline 26 & 38 & & & & & \\
\hline 27 & & & 27 & & & \\
\hline 28 & & 55 & & & & \\
\hline 29 & 192 & & & & & \\
\hline 30 & & 49 & & & & \\
\hline 31 & 110 & & & & & $\begin{array}{l}\text { Section } \\
\text { Total: }\end{array}$ \\
\hline Total Thickness $(\mathrm{cm})$ & 1479 & 533 & 203 & 255 & 10 & 2480 \\
\hline Percentage & $59.64 \%$ & $21.49 \%$ & $8.19 \%$ & $10.28 \%$ & $0.40 \%$ & \\
\hline Sum of Similar Facies & & $81.13 \%$ & & $18.47 \%$ & & \\
\hline
\end{tabular}




\begin{tabular}{|c|c|c|c|c|c|c|}
\hline \multirow{2}{*}{\begin{tabular}{|l} 
Dutch Flat South \\
$39^{\circ} 2^{\prime} 9.26^{\prime \prime} \mathrm{N}$ \\
$110^{\circ} 57^{\prime} 8.69^{\prime \prime} \mathrm{W}$ \\
Unit \# \\
\end{tabular}} & \multicolumn{5}{|c|}{ Facies Association } & \\
\hline & $A$ & $\mathrm{~B}$ & $\mathrm{C}$ & $\mathrm{D}$ & (Ash) & \\
\hline 1 & & & 65 & & & \\
\hline 2 & 320 & & & & & \\
\hline 3 & & 20 & & 20 & & \\
\hline 4 & & 15 & & 10 & & \\
\hline 5 & & 15 & & 8 & & \\
\hline 6 & & & 75 & & & \\
\hline 7 & & & & 450 & & \\
\hline 8 & 185 & & & & & \\
\hline 9 & & & & & 35 & \\
\hline 10 & 125 & & & & & \\
\hline 11 & & 100 & & & & \\
\hline 12 & 410 & & & & & \\
\hline 13 & & 25 & & & & \\
\hline 14 & 120 & 40 & & & & \\
\hline 15 & 30 & 150 & & & & \\
\hline 16 & 180 & & & & & \\
\hline 17 & & 20 & & & & \\
\hline 18 & 180 & & & & & $\begin{array}{l}\text { Section } \\
\text { Total: }\end{array}$ \\
\hline Total Thickness (cm) & 1550 & 385 & 140 & 488 & 35 & 2598 \\
\hline Percentage & $59.66 \%$ & $14.82 \%$ & $5.39 \%$ & $18.78 \%$ & $1.35 \%$ & \\
\hline Sum of Similar Facies & & $74.48 \%$ & & $24.17 \%$ & & \\
\hline
\end{tabular}




\begin{tabular}{|c|c|c|c|c|c|c|}
\hline $\begin{array}{l}\text { Dutch Flat North } \\
39^{\circ} 2^{\prime} 22.85^{\prime \prime} \mathrm{N} \\
110^{\circ} 57^{\prime} 2.24^{\prime \prime} \mathrm{W}\end{array}$ & & Facie & Associat & & & \\
\hline Unit \# & A & B & C & D & (Ash) & \\
\hline 1 & & & 32 & & & \\
\hline 2 & & & 28 & & & \\
\hline 3 & & & 25 & & & \\
\hline 4 & 72 & & & & & \\
\hline 5 & & & & 75 & & \\
\hline 6 & & 25 & & & & \\
\hline 7 & 190 & & & & & \\
\hline 8 & & & & 220 & & \\
\hline 9 & 45 & & & & & \\
\hline 10 & & & 23 & & & \\
\hline 11 & & & & 8 & & \\
\hline 12 & 25 & & & & & \\
\hline 13 & & 18 & & & & \\
\hline 14 & & & 65 & & & \\
\hline 15 & & & & 350 & & \\
\hline 16 & 120 & & & & & \\
\hline 17 & & & & & 15 & \\
\hline 18 & 710 & & & & & \\
\hline 19 & & 130 & & & & \\
\hline 20 & 310 & & & & & \\
\hline 21 & & 45 & & & & \\
\hline 22 & 30 & & & & & \\
\hline 23 & 40 & & & & & \\
\hline 24 & 75 & & & & & \\
\hline 25 & 100 & 100 & & & & \\
\hline 26 & 155 & & & & & \\
\hline 27 & & & 18 & & & \\
\hline 28 & & 20 & & & & \\
\hline 29 & 90 & & & & & \\
\hline 30 & 30 & & & & & \\
\hline 31 & 60 & & & & & \\
\hline 32 & 215 & & & & & $\begin{array}{l}\text { Section } \\
\text { Total: }\end{array}$ \\
\hline Total Thickness (cm) & 2267 & 338 & 191 & 653 & 15 & 3464 \\
\hline Percentage & $65.44 \%$ & $9.76 \%$ & $5.51 \%$ & $18.85 \%$ & $0.43 \%$ & \\
\hline Sum of Similar Facies & & $75.20 \%$ & & $24.36 \%$ & & \\
\hline
\end{tabular}




\begin{tabular}{|c|c|c|c|c|c|c|}
\hline $\begin{array}{l}\text { Green River Cutoff } \\
39^{\circ} 10^{\prime} 35.82^{\prime \prime} \mathrm{N} \\
110^{\circ} 48^{\prime} 12.13^{\prime \prime} \mathrm{W}\end{array}$ & \multicolumn{5}{|c|}{ Facies Association } & \\
\hline Unit \# & $A$ & B & $\mathrm{C}$ & $\mathrm{D}$ & $E$ & \\
\hline 1 & & & & 215 & & \\
\hline 2 & & & 40 & & & \\
\hline 3 & 450 & & & & & \\
\hline 4 & & & 35 & 35 & & \\
\hline 5 & & & 30 & & & \\
\hline 6 & & 15 & & & & \\
\hline 7 & 20 & & & & & \\
\hline 8 & & & & 130 & & \\
\hline 9 & & & 35 & & & \\
\hline 10 & & & & 110 & & \\
\hline 11 & & & 25 & & & \\
\hline 12 & & & & 130 & & \\
\hline 13 & 220 & & & & & \\
\hline 14 & & & & & 25 & \\
\hline 15 & 810 & & & & & \\
\hline 16 & & 90 & & & & \\
\hline 17 & 540 & & & & & \\
\hline 18 & 55 & & & & & \\
\hline 19 & & & 40 & & & \\
\hline 20 & & 105 & & & & \\
\hline 21 & 665 & & & & & $\begin{array}{l}\text { Section } \\
\text { Total: }\end{array}$ \\
\hline Total Thickness $(\mathrm{cm})$ & 2760 & 210 & 205 & 620 & 25 & 3820 \\
\hline Percentage & $72.25 \%$ & $5.50 \%$ & $5.37 \%$ & $16.23 \%$ & $0.65 \%$ & \\
\hline Sum of Similar Facies & & $77.75 \%$ & & $21.60 \%$ & & \\
\hline
\end{tabular}




\begin{tabular}{|c|c|c|c|c|c|c|c|}
\hline $\begin{array}{l}\text { Cedar Mesa } \\
39^{\circ} 12^{\prime} 0.09^{\prime \prime} \mathrm{N} \\
110^{\circ} 45^{\prime} 23.38^{\prime \prime} \mathrm{W}\end{array}$ & & & Facies As & sociation & & & \\
\hline Unit \# & A & B & $\mathrm{C}$ & $\mathrm{D}$ & (Ash) & Other & \\
\hline 1 & & & & & 50 & & \\
\hline 2 & 300 & & & & & & \\
\hline 3 & & & 10 & & & & \\
\hline 4 & & & 15 & & & & \\
\hline 5 & & 40 & & & & & \\
\hline 6 & 479 & & & & & & \\
\hline 7 & & 30 & & & & & \\
\hline 8 & & & 80 & & & & \\
\hline 9 & & 20 & & & & & \\
\hline 10 & & & 40 & & & & \\
\hline 11 & & 65 & & & & & \\
\hline 12 & 320 & & & & & & \\
\hline 13 & & 25 & & & & & \\
\hline 14 & & & & 70 & & & \\
\hline 15 & & & 35 & & & & \\
\hline 16 & & 35 & & & & 60 & \\
\hline 17 & 25 & & & & & & \\
\hline 18 & & 60 & & & & & \\
\hline 19 & & & & & & 135 & \\
\hline 20 & 970 & & & & & & \\
\hline 21 & & & & & & 240 & \\
\hline 22 & 450 & & & & & & \\
\hline 23 & 90 & & & & & & \\
\hline 24 & & & & 200 & & & \\
\hline 25 & 45 & & & & & & \\
\hline 26 & 35 & & & & & & \\
\hline 27 & & & & & & 10 & \\
\hline 28 & & 15 & & & & & \\
\hline 29 & 450 & & & & & & $\begin{array}{l}\text { Section } \\
\text { Total: }\end{array}$ \\
\hline Total Thickness $(\mathrm{cm})$ & 3164 & 290 & 180 & 270 & 50 & 445 & 4399 \\
\hline Percentage & $71.93 \%$ & $6.59 \%$ & $4.09 \%$ & $6.14 \%$ & $1.14 \%$ & $10.12 \%$ & \\
\hline $\begin{array}{l}\text { Sum of Similar } \\
\text { Facies }\end{array}$ & & $78.52 \%$ & & $10.23 \%$ & & & \\
\hline
\end{tabular}




\section{APPENDIX B}

Paleocurrent measurements and rose diagrams.

Table 2. Paleocurrent measurements. Gray cells mark measurements taken above tephra.

\begin{tabular}{|c|c|c|c|c|c|}
\hline \multicolumn{6}{|c|}{ Paleo Current Measurements } \\
\hline & $2 \mathrm{D}$ & $3 \mathrm{D}$ & & $2 \mathrm{D}$ & $3 D$ \\
\hline \multirow[t]{3}{*}{ Cedar Mesa } & 110 & & Dutch Flat South & 122 & 69 \\
\hline & 175 & & & 110 & 128 \\
\hline & & & & 115 & 136 \\
\hline \multirow[t]{11}{*}{ Green River Cutoff } & 115 & & & 104 & 90 \\
\hline & 83 & & & 97 & 103 \\
\hline & 75 & & & & \\
\hline & 95 & & Moore Road North & 136 & 100 \\
\hline & 111 & & & 65 & 122 \\
\hline & 75 & & & & 106 \\
\hline & 147 & & & & \\
\hline & 65 & & Moore Road South & 196 & 60 \\
\hline & 107 & & & 200 & 36 \\
\hline & 349 & & & 157 & \\
\hline & & & & 60 & 315 \\
\hline \multirow[t]{10}{*}{ Dutch Flat North } & 114 & 110 & & 57 & 328 \\
\hline & 107 & 109 & & 80 & 142 \\
\hline & 78 & 104 & & 110 & \\
\hline & 79 & 104 & & & \\
\hline & 80 & 169 & $\mathrm{I}-70$ & 90 & 95 \\
\hline & 82 & 86 & & 80 & 104 \\
\hline & 80 & 132 & & 104 & \\
\hline & 60 & & & & \\
\hline & 124 & & & & \\
\hline & 120 & & & & \\
\hline
\end{tabular}




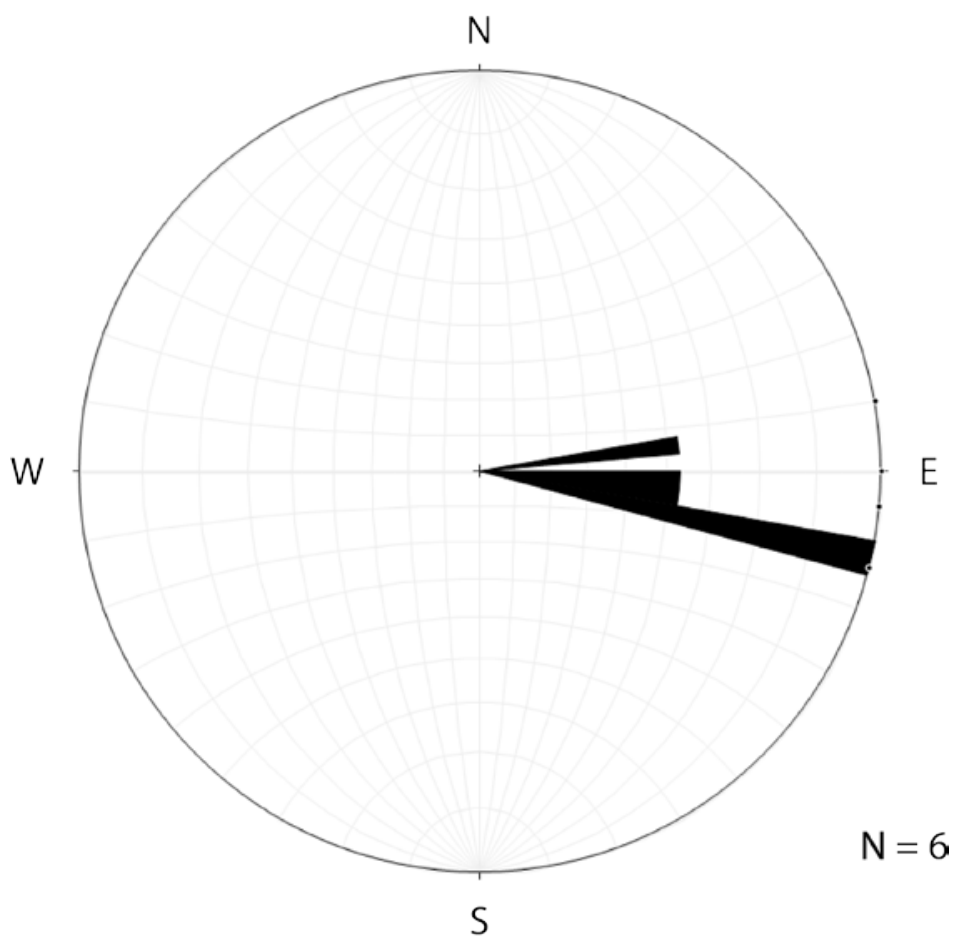

Figure 44. Paleocurrent measurements for the I-70 section.

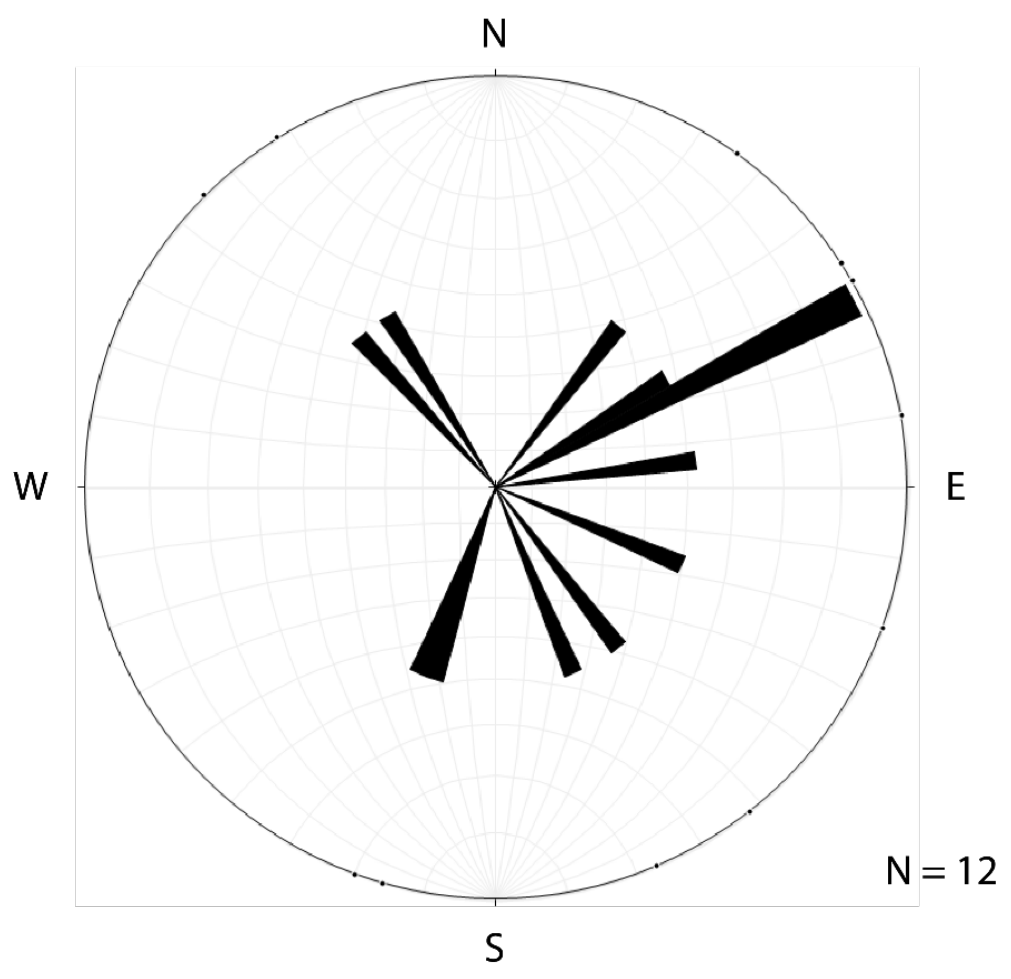

Figure 45. Paleocurrent measurements for the Moore Road South section. Note some paleocurrent directions are opposite to others (NW trending samples). They may represent supercritical bedforms, in which case their flow direction should be reinterpreted opposite $\left(180^{\circ}\right)$ from their plotted value. 


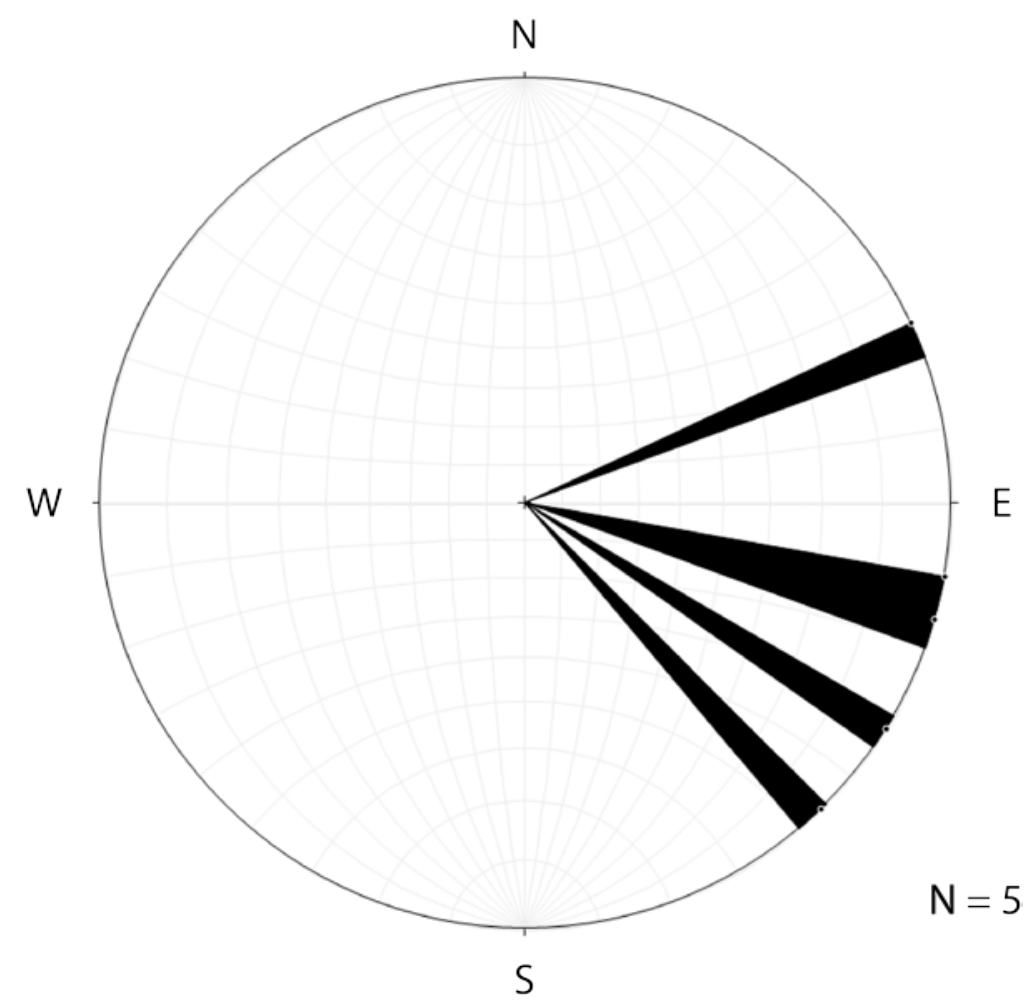

Figure 46. Paleocurrent measurements for the Moore Road North section.

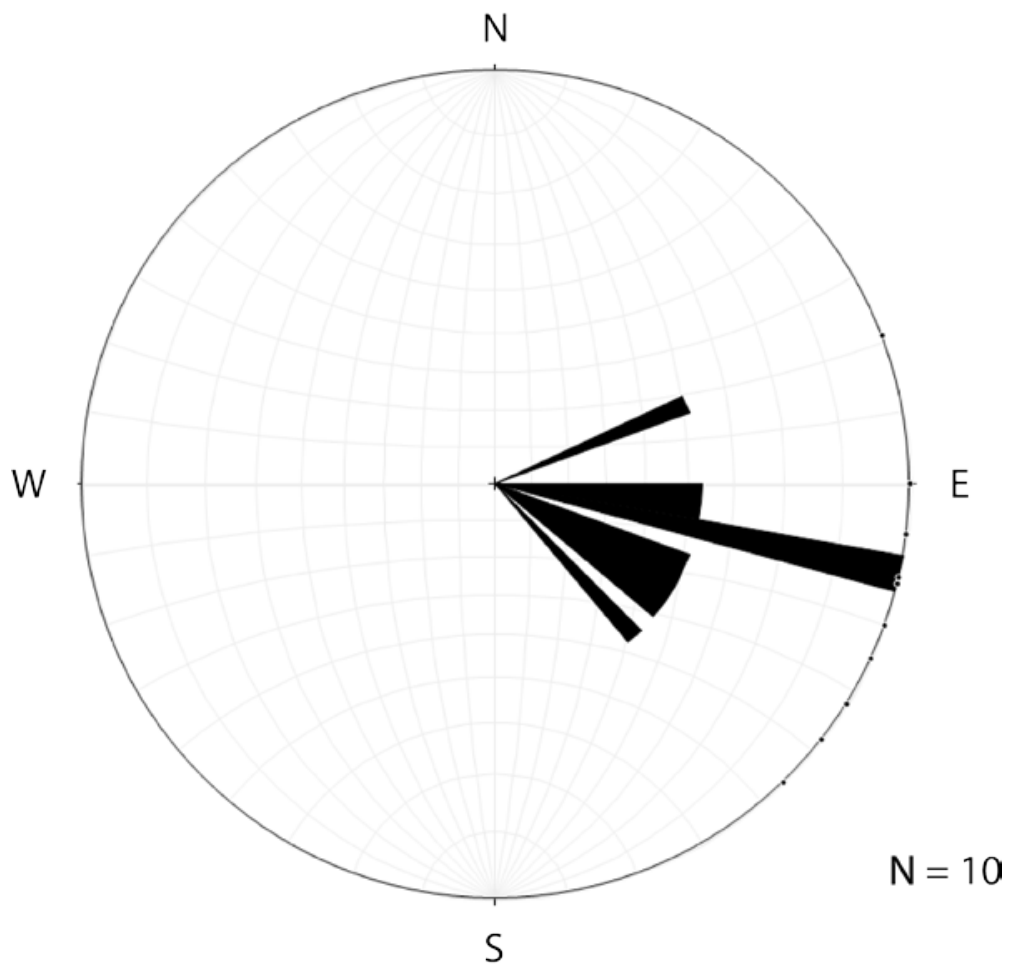

Figure 47. Paleocurrent measurements for the Dutch Flat South section. 


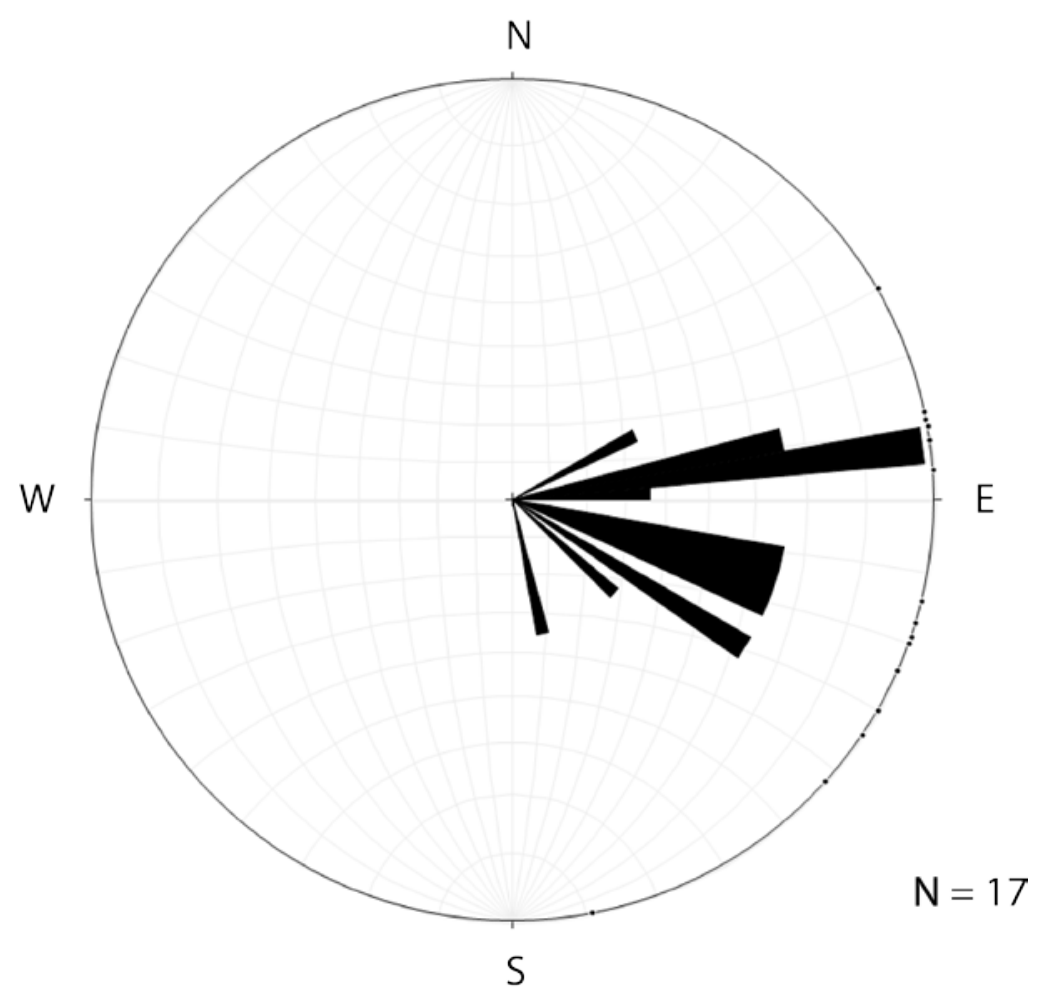

Figure 48. Paleocurrent measurements for the Dutch Flat North section.

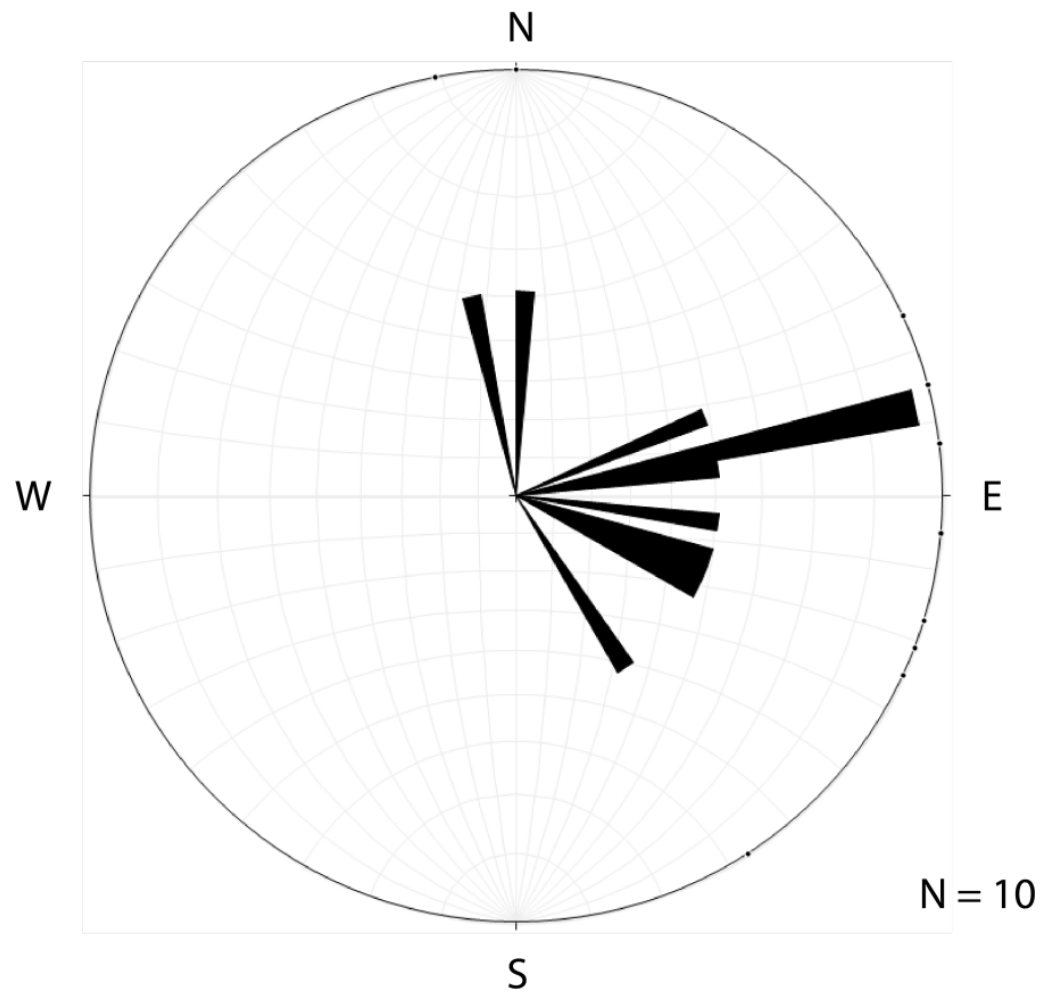

Figure 49. Paleocurrent measurements for the Green River Cutoff section. 


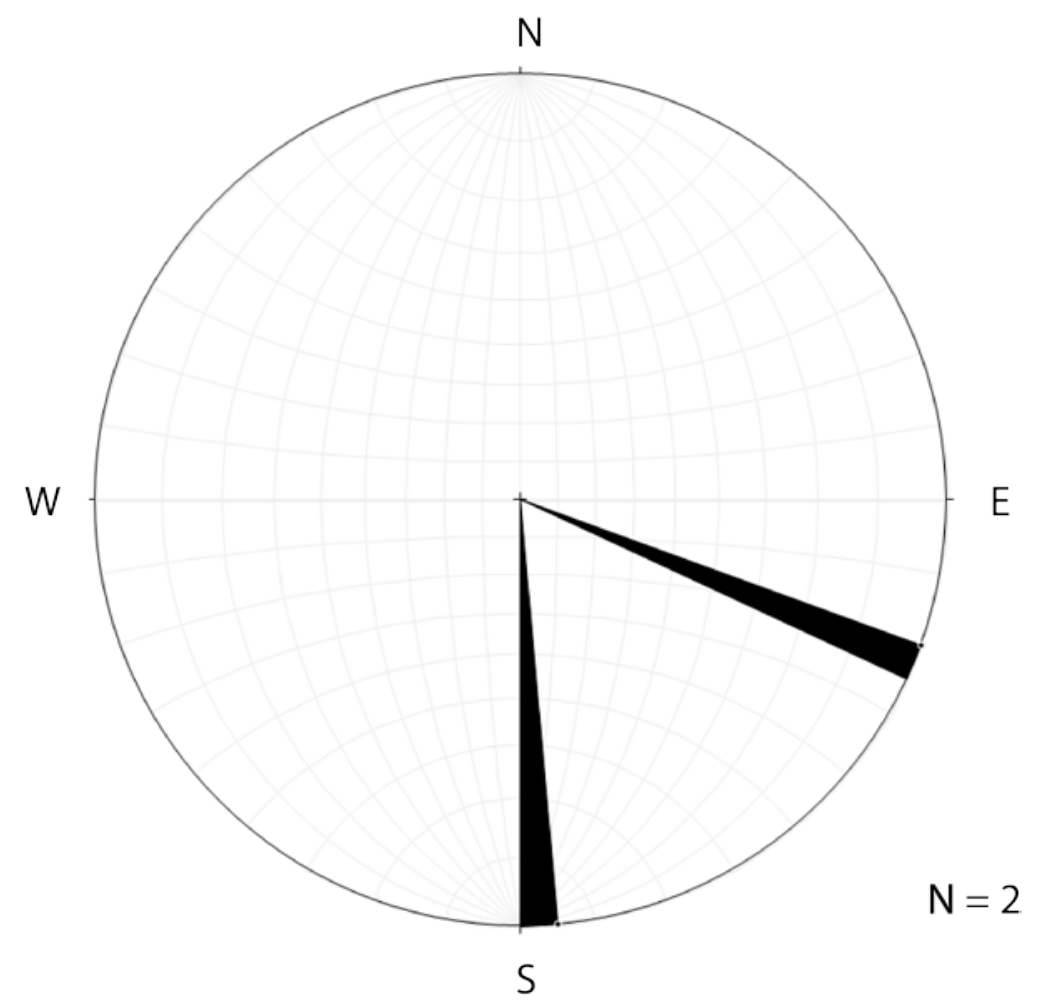

Figure 50. Paleocurrent measurements for the Cedar Mesa section. 